Aus der Abteilung Mund-, Kiefer- und Gesichtschirurgie

(Prof. Dr. med. Dr. med. dent. H. Schliephake)

im Zentrum Zahn-, Mund- und Kieferheilkunde

der Medizinischen Fakultät der Universität Göttingen

\title{
Proliferations- und Differenzierungsverhalten humaner Zahnkeimzellen der Pulpa
}

\author{
INAUGURAL - DISSERTATION \\ zur Erlangung des Doktorgrades \\ für Zahnheilkunde \\ der Medizinischen Fakultät \\ der Georg-August-Universität zu Göttingen
}

vorgelegt von

Andrea Mirja Gümmer

aus

Hannover

Göttingen 2011 
Dekan: Prof. Dr. med. C. Frömmel

1. Berichterstatter: Prof. Dr. med. Dr. med. dent. K. G. Wiese

2. Berichterstatter: Prof. Dr. med. Miosge

3. Berichterstatter/in:

Tag der mündlichen Prüfung: 15.11.2011 


\section{Inhaltsverzeichnis}

\section{ABKÜRZUNGSVERZEICHNIS \\ II ABBILDUNGSVERZEICHNIS \\ III TABELLENVERZEICHNIS}

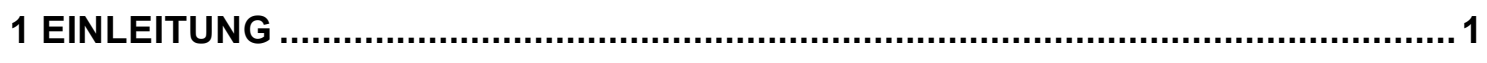

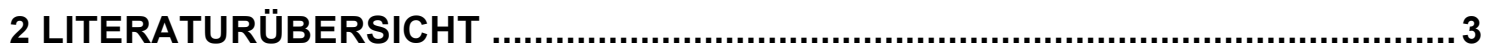

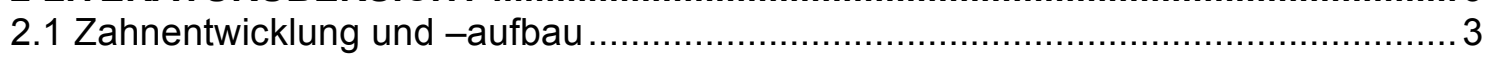

2.2 Mesenchymale Stammzellen und Stammzellmarker ......................................... 4

2.3 Dentale Stammzellen und Stammzellmarker............................................... 7

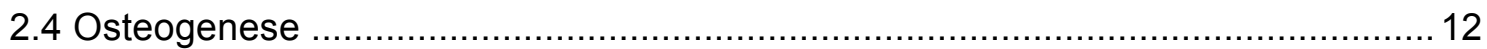

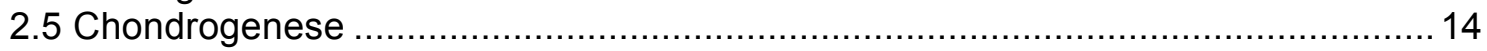

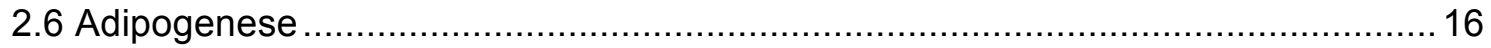

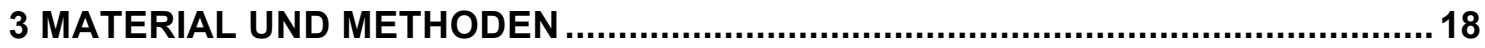

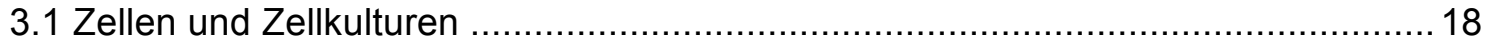

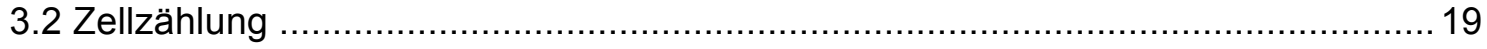

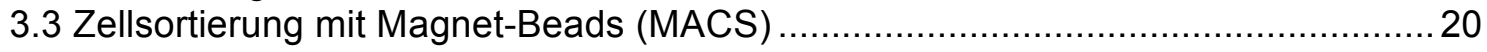

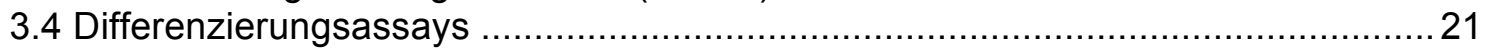

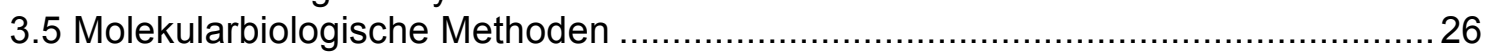

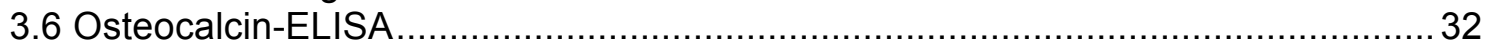

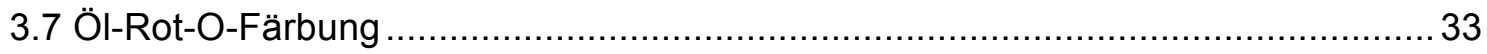

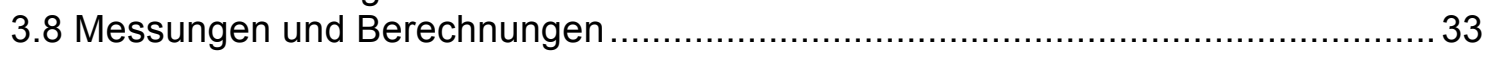

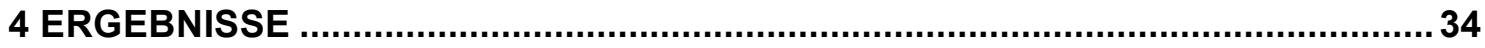

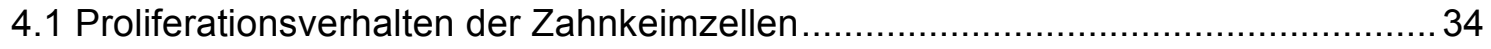

4.1.1 Proliferationsverhalten im osteogenen Differenzierungsmedium ....................... 35

4.1.2 Proliferationsverhalten im adipogenen Differenzierungsmedium ...................... 41

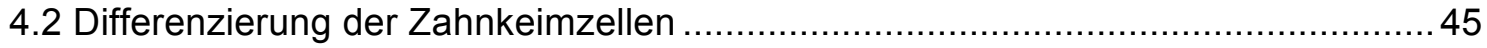

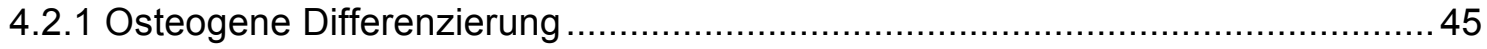

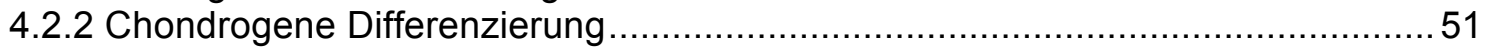

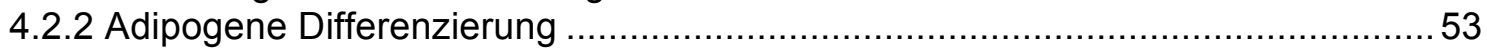

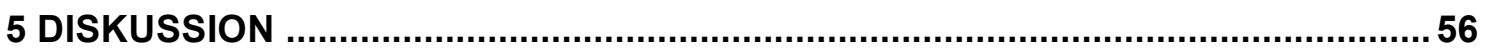

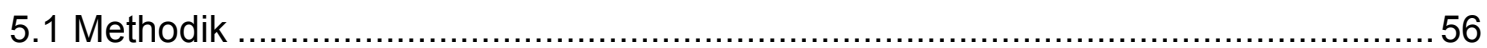

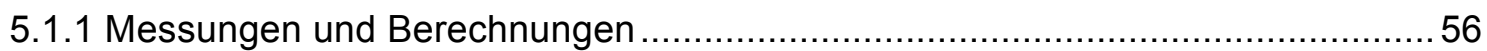

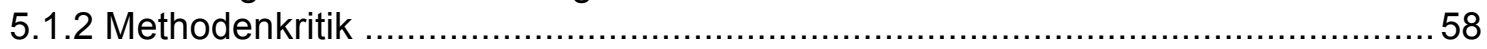

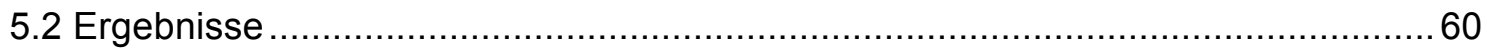

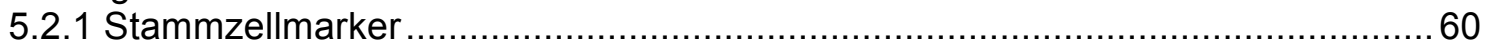

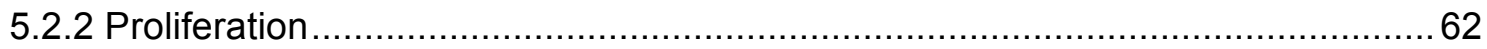

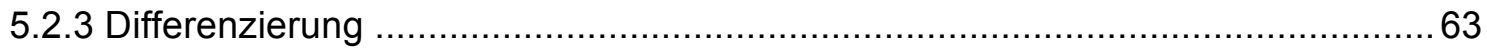

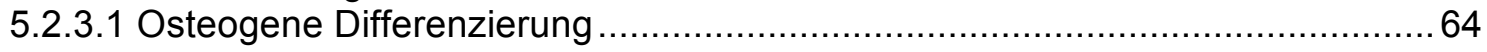

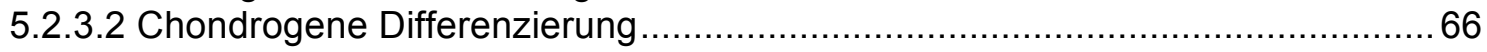

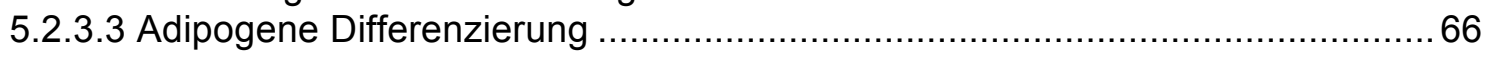

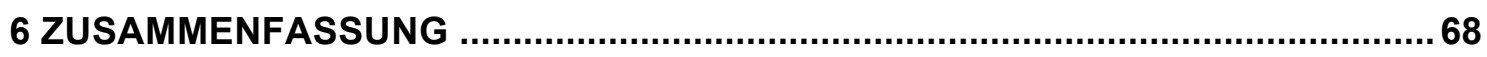

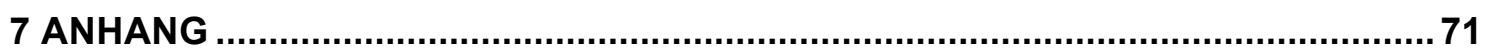

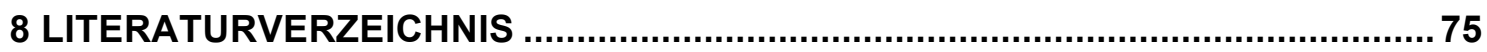




\section{Abkürzungsverzeichnis}

\begin{tabular}{|c|c|}
\hline Abb. & Abbildung \\
\hline Agg & Aggrecan \\
\hline AP & alkalische Phosphatase \\
\hline aP2 & adipocyte protein 2/FABP4 \\
\hline bidest. & bidestilliert \\
\hline BMP-2 & bone morphogenic protein 2 \\
\hline bp & Basenpaare \\
\hline BSA & Rinderserum-Albumin (englisch: bovine serum albumin) \\
\hline BSP & Bone sialoprotein \\
\hline bzgl. & bezüglich \\
\hline bzw. & beziehungsweise \\
\hline${ }^{\circ} \mathrm{C}$ & Celsius \\
\hline ca. & circa \\
\hline Cbfa1 & Core binding factor 1 \\
\hline CD & cluster of differentiation (CD-Molekül) \\
\hline cDNA & copy Desoxyribonukleinsäure \\
\hline $\mathrm{cm}^{2}$ & Quadratzentimeter \\
\hline c-myc & zelluläres Homolog des viralen Onkogens v-myc (Myelocytomatosis) \\
\hline Coll & Kollagen I \\
\hline Col1A1 & Kollagen Typ I alpha I \\
\hline d & Tag (englisch: day) \\
\hline dATP & Desoxyadenosintriphosphat \\
\hline dCTP & Desoxycytosintriphosphat \\
\hline d.h. & das heißt \\
\hline dGTP & Desoxyguanidintriphosphat \\
\hline $\operatorname{dim}$ & Dimensionalität \\
\hline DMEM & Dulbecco's Modified Eagle Medium \\
\hline DNA & Desoxyribonukleinsäure \\
\hline DNase & Desoxyribonuklease \\
\hline DPSC(s) & dentale Pulpa-Stammzelle(n) \\
\hline dTTP & Desoxythymidintriphosphat \\
\hline EDTA & Ethylendiamintetraacetat \\
\hline ELISA & emzym linked immunosorbent assay \\
\hline FABP4 & Fatty acid binding protein 4 \\
\hline FACS & fluorescence-activated cell-sorting \\
\hline FKS & fetales Kälberserum \\
\hline g & Erdbeschleunigung \\
\hline $3 G 5$ & Perizyten-assoziiertes Antigen \\
\hline
\end{tabular}




\begin{tabular}{|c|c|}
\hline GAPDH & Glycerinaldehyd-3-phosphat-Dehydrogenase \\
\hline GFAP & Glial fibrillary acidic protein \\
\hline HDFC(s) & humane dentale Follikel-Vorläuferzelle(n) \\
\hline hMSC(s) & humane mesenchymale Stammzelle(n) \\
\hline HRP & horseradish-peroxidase/Meerrettichperoxidase \\
\hline $\mathrm{H}_{2} \mathrm{SO}_{4}$ & Schwefelsäure \\
\hline $\lg G$ & Immunglobulin G \\
\hline JMAK-Formel & Johnson-Mehl-Avrami-Kolmogorow-Formel \\
\hline $\mathrm{k}$ & Geschwindigkeitskonstante des Wachstums \\
\hline KIf4 & Kruppel-like-factor 4 \\
\hline I & Liter \\
\hline LNGFR & low affinity nerve growth factor receptor \\
\hline LPL & Lipoprotein Lipase \\
\hline M & Marker \\
\hline $\mathrm{m}$ & Gesamtzellzahl im Maximum \\
\hline MACS & magnetic-activated cell-sorting \\
\hline $\max$ & maximal \\
\hline MEPE & matrix extracellular phosphoglycoprotein \\
\hline $\min$ & Minute \\
\hline Mio. & Millionen \\
\hline$\mu l$ & Mikroliter \\
\hline $\mathrm{ml}$ & Milliliter \\
\hline MMP & Matrix Metalloproteinase \\
\hline mRNA & messenger RNA \\
\hline MW & Mittelwert \\
\hline$n$ & Avrami-Exponent \\
\hline ng & Nanogramm \\
\hline $\mathrm{nm}$ & Nanometer \\
\hline $\mathrm{OCN}$ & Osteocalcin \\
\hline Oct $3 / 4$ & Octamer binding transcription factor 3/4 \\
\hline OD & Optische Dichte \\
\hline o.g. & oben genannt(en) \\
\hline Oligo(dT) & Oligonukleotide \\
\hline PBS & Phosphate Buffered Saline \\
\hline PCR & Polymerase-chain-reaction/Polymerase-Ketten-Reaktion \\
\hline PDL & Parodontales Ligament \\
\hline $\operatorname{PDLSC}(\mathrm{s})$ & periodontale Ligament-Stammzelle(n) \\
\hline pmol & Pikomol \\
\hline PPAR $\gamma$ & peroxisome proliferator-activated receptor \\
\hline $\mathrm{R}^{2}$ & Bestimmtheitskoeffizient der Regression \\
\hline RNA & Ribonukleinsäure \\
\hline
\end{tabular}




$\begin{array}{ll}\text { RNase } & \text { Ribonuklease } \\ \text { rpm } & \text { rotations per minute } \\ \text { RT } & \text { Reverse Transkriptase } \\ \text { RTq-PCR } & \text { quantitative Real-Time PCR } \\ \text { SCAP } & \text { stem cells from apical papilla } \\ \text { sec } & \text { Sekunde } \\ \text { SH2 } & \text { Src-homology 2 } \\ \text { SH3 } & \text { Src-homology 3 } \\ \text { SHED } & \text { stem cells from human exfoliated deciduous teeth } \\ \text { Sox2 } & \text { SRY (sex determining region Y)-box 2 } \\ \text { Sox9 } & \text { SRY (sex determining region Y)-box 9 } \\ \text { Stro-1 } & \text { stromal cell surface marker 1 } \\ \text { T } & \text { Temperatur } \\ \text { Tab. } & \text { Tabelle } \\ \text { TMB } & \text { Tetramethylbenzidine } \\ \text { u.a. } & \text { unter anderem } \\ \text { UMG } & \text { Universitätsmedizin Göttingen } \\ \text { w.E. } & \text { willkürliche Einheit } \\ \text { z.B. } & \text { zum Beispiel } \\ \text { z.T. } & \text { zum Teil } \\ & \end{array}$




\section{Abbildungsverzeichnis}

Abb. 1: Panoramaschichtaufnahmen mit einem gekennzeichneten Zahnkeim (a) und einem Dens permanens (b)

Abb. 2: Schematische Darstellung des Differenzierungspotentials mesenchymaler Stammzellen

Abb. 3: Schematische Darstellung der Genexpression des osteogenen Differenzierungsprozesses

Abb. 4: Schematischer Ablauf der osteogenen Differenzierung in vitro

Abb. 5: Vereinfachte Darstellung einzelner Phasen der Chondrogenese...

Abb. 6: Schematischer Ablauf der adipogenen Differenzierung ....

Abb. 7: Schematische Darstellung der MAC-Sortierung .

Abb. 8: Schematische Darstellung des Zeitverlaufs der adipogenen Versuchsreihe

Abb. 9: Schematische Darstellung des Versuchsaufbaus des chondrogenen Assays

Abb. 10: Schematische Darstellung des Zeitverlaufs der osteogenen Versuchsreihe

Abb. 11: Schematische Darstellung eines „enzyme linked immunosorbent assays“ (ELISA) ... 33

Abb. 12: Proliferationsverhalten der Stro- $1^{+/-}-, \mathrm{CD} 133^{+/-}$- und $\mathrm{CD} 271^{+/-}$-Zellen im osteogenen Differenzierungsmedium .....

Abb. 13: Maximale Wachstumsgeschwindigkeiten mit entsprechenden Peaks der Stro- $1^{+/-}$, $\mathrm{CD}_{133^{+/-} \text {- und CD271 }}^{+/-}$-Zellen des osteogenen Assays.

Abb. 14: Proliferationsstadien der Stro- $1^{+/-}-, C D 271^{+/-}-, C D 133^{+/-}$-Zellen des osteogenen Differenzierungsassays.

Abb. 15: Proliferationsverhalten der Stro- $1^{+/-}-, C D 133^{+/-}$und $C D 271^{+/-}$-Zellen des adipogenen Assays

Abb. 16: Maximale Wachstumsgeschwindigkeiten mit entsprechenden Peaks der Stro- $1^{+/-}$-, $\mathrm{CD}_{133^{+/-} \text {- und CD271 }}^{+/-}$-Zellen des adipogenen Assays.

Abb. 17: Proliferationsstadien der Stro- $1^{+/-}-, C D 271^{+/-}-$und CD133 ${ }^{+/-}$-Zellen im adipogenen Differenzierungsmedium .

Abb. 18: OCN-Konzentration und das Proliferationsverhalten der Stro- $1^{+/-}$-Zellen des osteogenen Differenzierungsassays

Abb. 19: OCN-Konzentration und das Proliferationsverhalten der CD271 ${ }^{+/-}$-Zellen des osteogenen Differenzierungsassays. 
Abb. 20: OCN-Konzentration und das Proliferationsverhalten der $\mathrm{CD} 133^{+/}$-Zellen des osteogenen Differenzierungsassays

Abb. 21: Expression osteogener Differenzierungsmarker mittels PCR im

Osteoblastendifferenzierungsmedium 50

Abb. 22: Expression des osteogenen Differenzierungsmarkers Osteocalcin anhand einer RTqPCR im Osteoblastendifferenzierungsmedium

Abb. 23: Expression des „housekeeping“-Gens GAPDH mittels PCR im Chondrozytendifferenzierungsmedium

Abb. 24: Expression des chondrogenen Differenzierungsmarkers Aggrecan und des Transkriptionsfaktors Sox9 mittels PCR im Chondrozytendifferenzierungsmedium

Abb. 25: Expression des chondrogenen Differenzierungsmarkers Chondroadherin mittels PCR im Chondrozytendifferenzierungsmedium.

Abb. 26: Expression verschiedener Differenzierungsmarker mittels PCR im Adipozytendifferenzierungsmedium.....

Abb. 27: Öl-Rot-O-Färbung der Zahnkeimzellen des adipogenen Assays

Abb. 28: Einfluss des Avrami-Exponenten $\mathrm{n}$ auf die sigmoidale Form der Wachstumskurve bei konstanter Wachstumsgeschwindigkeitskonstante. 57

Abb. 29: Einfluss der Wachstumsgeschwindigkeitskonstanten $\mathrm{k}$ auf den Verlauf der Kurve bei konstantem Avrami-Exponenten 


\section{Tabellenverzeichnis}

Tab. 1: Schematische Darstellung des adipogenen Versuchsaufbaus

Tab. 2: Schematische Darstellung des osteogenen Versuchsaufbaus.

Tab. 3: Auflistung der Ziel-Gene, Primer-Sequenzen, Annealing-Temperaturen und die Fragmentgröße der cDNA.

Tab. 4: Relative und absolute Zellzahlen der Zahnkeimpopulationen nach der MAC-Sortierung mit den Stammzellmarkern Stro-1, CD133 und CD271.....

Tab. 5: Maximale Zellzahl, die Wachstumsgeschwindigkeitskonstante $(k)$ der Stro- $1^{+/-}$, $\mathrm{CD}_{133^{+/-} \text {- und CD271 }}^{+/-}$-Zellen im osteogenen Differenzierungsmedium

Tab. 6: Maximale Wachstumsgeschwindigkeiten der Stro- $1^{+/-}-, C D 133^{+/-}$- und CD271 ${ }^{+/-}$-Zellen im osteogenen Differenzierungsmedium

Tab. 7: Maximale Zellzahl, die Wachstumsgeschwindigkeitskonstante k der Stro- ${ }^{+/-}-, \mathrm{CD}_{133^{+/}}$und CD271 ${ }^{+/-}$-Zellen im adipogenen Differenzierungsmedium

Tab. 8: Maximale Wachstumsgeschwindigkeiten der Stro- $1^{+/-}-$, CD $133^{+/-}$- und CD271 $1^{+/-}$Zellen im adipogenen Differenzierungsmedium

Tab. 9: Zellkulturreagenzien und Zellkulturzubehör

Tab. 10: Nachweismaterialien und Gebrauchslösungen . 72

Tab. 11: Geräte und Verbrauchsmaterialien 


\section{Einleitung}

Die Zähne des Menschen bestehen aus der härtesten Substanz des menschlichen Körpers und sind das einzige Hartgewebe, das nicht vollständig von Weichgewebe umgeben ist (SCHIEBLER und SCHMIDT 1999 a). Die Vorläufer der menschlichen Zähne sind auf zahnähnliche Strukturen der Körperoberfläche kieferloser Fische zurückzuführen (KOUSSOULAKOU et al. 2009). Im Laufe von 500.000.000 Jahren Evolution sind etliche dieser Strukturen nach einer Vielzahl von Mutationen in die Mundhöhle gewandert. Dieser Prozess wird beispielsweise bei den neuzeitlichen Haien sichtbar. Die Zähne des Hais bilden sich aus modifizierten Placoidschuppen, breiten sich vom Maul als kleine Hautzähnchen über den gesamten Körper aus und bilden das Exoskelett. Die wurzellosen Haizähne sind denen des Menschen homolog: sie besitzen einen pulpaähnlichen Hohlraum, der von Dentin und Schmelz umgeben ist. Der Hai ist im Gegensatz zum Menschen in der Lage, zeitlebens neue Zähne zu bilden, so dass nach Zahnverlust sofort neue Zähne nachrücken. Er verfügt über ein sogenanntes „Revolvergebiss“. Der evolutionäre Weg verläuft vom kieferlosen Fisch über das Reptil bis hin zum Säugetier und ist durch eine Abnahme der Zahnzahl, der Zahngenerationen sowie durch eine Zunahme der Komplexität der Zahnmorphologie gekennzeichnet (KOUSSOULAKOU et al. 2009). Das menschliche Gebiss ist diphydont, oligodont und heterodont, d.h. es verfügt über zwei Zahngenerationen, die Milchzähne (Dentes decidui) und die bleibenden Zähne (Dentes permanentes), welche maximal 20 bzw. 32 Zähne aufweisen. Darüber hinaus unterscheiden sich die menschlichen Zähne in ihrer Morphologie: es existieren die Schneidezähne (Dentes incisivi), die Eckzähne (Dentes canini), die Prämolaren (Dentes praemolares) und die Molaren (Dentes molares). Allen Zähnen gemeinsam ist der makroskopische Zahnaufbau, bestehend aus Krone (Corona dentis), Wurzel (Radix dentis), Zahnhals (Cervix oder Collum dentis) und Wurzelspitze (Apex dentis) (SCHIEBLER und SCHMIDT 1999 a).

Die Zahnentwicklung des Menschen beginnt im 2. Embryonalmonat und beruht auf der Interaktion von dentalen Geweben des ektodermalen Keimblattes und des aus der Neuralleiste stammenden ektomesenchymalen Keimblattes (YEN und SHARPE 2006). Der Schmelz entsteht aus einer epithelialen Aussprossung des Ektoderms. Dieses epitheliale Gewebe aktiviert das angrenzende dentale, ektomesenchymale Gewebe, aus dem das Dentin, das Parodontium und die Zahnpulpa hervorgehen. Die schmelzbildenden Ameloblasten gehen nach der Zahneruption verloren. Daher sind Menschen nicht in der Lage, posteruptiv neuen Zahnschmelz zu bilden. Aus dem ektomesenchymalen Gewebe entwickeln sich die Zellen des Zahnhalteapparates und der Zahnpulpa. Zu den letzteren zählen u.a. die Odontoblasten, welche das Dentin bilden. Die Odon- 
toblasten bleiben ein Leben lang aktiv und sind an limitierten Reparaturvorgängen des Zahn-Pulpa-Komplexes wie der Tertiärdentinbildung beteiligt (SHI et al. 2001). Diese Eigenschaft rückte die Pulpazellen in den Focus wissenschaftlicher Untersuchungen. So konnte z.B. in verschiedenen Studien gezeigt werden, dass menschliche Zähne tatsächlich eine Quelle für die Gewinnung adulter Stammzellen darstellen (GRONTHOS et al. 2000). Es können derzeit fünf verschiedene humane dentale Stammzellen/Progenitorzellen isoliert und charakterisiert werden (HUANG et al. 2009): die dentalen Pulpa-Stammzellen (DPSCs) (D'AQUINO et al. 2007, GRONTHOS et al. 2000, IOHARA et al. 2006, KERKIS et al. 2006), die dentalen „stem cells from human exfoliated deciduous teeth" (SHEDs) (MIURA et al. 2003), die periodontalen LigamentStammzellen (PDLSCs) (SEO et al. 2004), die dentalen "stem cells from apical papilla“ (SCAPs) und die humanen dentalen Follikel-Vorläuferzellen (HDFCs) (MORSCZECK et al. 2005 b, MORSCZECK 2006).

Die oben genannten Studien wurden überwiegend mit extrahierten Weisheitszähnen oder exfoliierten Milchzähnen durchgeführt (GRONTHOS et al. 2000, MIURA et al. 2003), so dass bislang hauptsächlich Zellen aus der Pulpa von Zähnen mit abgeschlossenem Wurzelwachstum charakterisiert wurden. Interessant wäre jedoch eine Untersuchung der Pulpazellen von Zahnkeimen, bei denen sich Zahnkrone und Zahnwurzeln noch im Wachstum befinden. Daher wurden im Rahmen dieser Studie Zellpopulationen charakterisiert, welche der Pulpa von Zahnkeimen entstammten. Die hier verwendeten Zahnkeime wurden aus kieferorthopädischen Gründen extrahiert. Ferner fällt auf, dass in den bisher vorliegenden Arbeiten die „Stammzellen“ dieser Zahnkeime nicht genauer charakterisiert wurden und in der Literatur derzeit nur unzureichende Erkenntnisse bzgl. des Stammzellpotentials der Zahnkeime existieren. Es war daher das Ziel dieser Studie zu untersuchen, ob die Pulpazellen der Zahnkeime multipotente Stammzellen beinhalten, die adipogenes, osteogenes und chondrogenes Differenzierungspotential aufweisen. Dazu sollte das Proliferations- und Differenzierungsverhalten der Zahnkeimzellen untersucht werden. 


\section{Literaturübersicht}

\subsection{Zahnentwicklung und -aufbau}

Die Zahnentwicklung beginnt in der 5. Embryonalwoche und beruht auf der Interaktion von dentalen Geweben des ektodermalen Keimblattes und des aus der Neuralleiste stammenden ektomesenchymalen Keimblattes. Die Zähne entstehen bei Säugetieren aus dem 1. Kiemenbogen des Embryos. Die Zahnentwicklung geht vom dentalen Ektoderm aus, welches das angrenzende dentale, ektomesenchymale Gewebe für die Zahnkeimbildung aktiviert (YEN und SHARPE 2006). Der Schmelz entsteht aus einer epithelialen Aussprossung des Ektoderms und wird von den Ameloblasten synthetisiert. Die schmelzbildenden Ameloblasten gehen nach der Zahneruption verloren. Daher sind Menschen nicht in der Lage, posteruptiv neuen Zahnschmelz zu bilden. Die Zellen des Zahnhalteapparates, des Dentins und der Zahnpulpa sind ektomesenchymalen Ursprungs. Zu den Zellen der Zahnpulpa zählen u.a. die Odontoblasten, welche das Dentin bilden. Im Gegensatz zu den Ameloblasten bleiben sie ein Leben lang aktiv und sind an limitierten Reparaturvorgängen des Zahn-Pulpa-Komplexes, wie beispielsweise der Tertiärdentinbildung beteiligt (SHI et al. 2001).

Das menschliche Gebiss unterliegt einem einmaligen Zahnwechsel (Diphydontie). Die Zähne der 1. Dentition werden, wie schon auf Seite 1 erwähnt, als Milchzähne (Dentes decidui) und die der 2. Dentition als bleibende Zähne (Dentes permanentes) bezeichnet. Die 1. Dentition verfügt über 20 Milchzähne, während das bleibende Gebiss maximal 32 Zähne enthält (Oligodontie). Darüber hinaus existieren morphologisch unterschiedliche Zahnformen: Schneidezähne (Dentes incisivi), Eckzähne (Dentes canini), Prämolaren (Dentes praemolares) und Molaren (Dentes molares) (Heterodontie). Der makroskopische Zahnaufbau aller Zahnformen besteht aus der Zahnkrone (Corona dentis), der Zahnwurzel (Radix dentis), dem Zahnhals (Cervix oder Collum dentis) und der Wurzelspitze (Apex dentis) (SCHIEBLER und SCHMIDT 1999 a). Mikroskopisch setzen sich die Zähne aus dem Zahnbein (Dentin), dem Zahnschmelz (Enamelum), dem Zement (Cementum) und der Pulpa zusammen. Schmelz, Dentin und Zement stellen gemeinsam die Zahnhartsubstanz des menschlichen Zahnes dar. Den Hauptteil der Zahnhartsubstanzen bildet das Dentin, welches im Bereich der Krone von Schmelz und im Bereich der Wurzel von Zement umgeben ist. Innerhalb dieses Hartsubstanzmantels befindet sich die Pulpahöhle (Cavitas dentis), die sich in den Wurzelkanal (Canalis radicis dentis) fortsetzt. Beide beinhalten die Zahnpulpa, welche sich topographisch in Kronen- und Wurzelpulpa unterscheiden lässt. Histologisch besteht die Pulpa hauptsächlich aus lockerem Bindegewebe. Neben kollagenen Fasern lassen sich Ge- 
fäße, Nerven sowie verschiedene Zelltypen finden. Bei letzteren handelt es sich um Fibroblasten, Odontoblasten, Abwehrzellen und undifferenzierte Mesenchymzellen (SCHIEBLER und SCHMIDT 1999 a). Abbildung 1 zeigt die röntgenologische Darstellung eines Zahnkeims (a) und eines bleibenden Zahnes mit abgeschlossenem Wurzelwachstum (Dens permanens) (b).
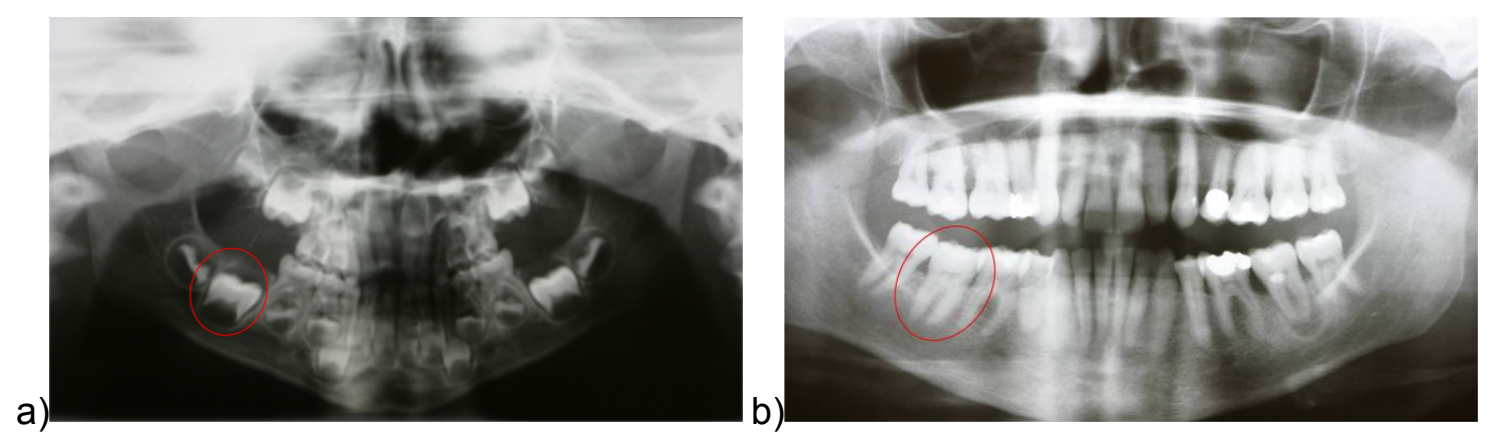

Abb. 1: Die Abbildungen zeigen jeweils eine Panoramaschichtaufnahmen mit einem gekennzeichneten Zahnkeim (a) und einem Dens permanens (b).

\subsection{Mesenchymale Stammzellen und Stammzellmarker}

Der Definition nach handelt es sich bei mesenchymalen Stammzellen um sich selbst erneuernde multipotente Vorläuferzellen, die in der Lage sind, in unterschiedliche mesenchymale Phänotypen zu differenzieren. Das Regenerations- und Differenzierungspotential adulter Stammzellen beschränkt sich nicht nur auf das Gewebe, in dem sie vorzufinden sind. So konnte in vorangegangenen Studien bereits belegt werden, dass Zellpopulationen des Knochenmarks neben der Erneuerung des hämatopoetischen Systems ebenso zur Erneuerung von Muskeln, Gehirn, Fett und vaskulärem Endothel fähig sind (BLAU et al. 2001, FERRARI et al. 1998, KOCHER et al. 2001, ORLIC et al. 2001, PETERSEN et al. 1999, PITTENGER et al. 1999).

Die Mechanismen der Transdifferenzierung adulter Stammzellen in andere Zelltypen werden derzeit noch nicht vollständig verstanden. Es wird aber vermutet, dass adulte Stammzellen durch spezifische bis dato noch unbekannte Proteine reprogrammiert werden und sich somit in verschiedene Zelltypen differenzieren können. Das Vorhandensein multipotenter Eigenschaften bei embryonalen Stammzellen wird auf die Expression der sogenannten Yamanaka-Faktoren zurückgeführt, die als Oct 3/4, Sox2, c-myc und Klf4 bekannt sind (TAKAHASHI und YAMANAKA 2006). Inwiefern die Faktoren auch das Verhalten bezüglich multipotenter Eigenschaften von adulten Stammzellen prägen, wird derzeit noch kontrovers diskutiert. Des Weiteren wird angenommen, dass bestimmte Faktoren wie z.B. basale Nährstoffe, Zelldichte, räumliche Orga- 
nisation, mechanische Kräfte, Wachstumsfaktoren oder Zytokine Einfluss auf die Differenzierung und Proliferation humaner Stammzellen nehmen (PITTENGER et al. 1999).

Es konnte gezeigt werden, dass einige adulte Stammzellarten in vitro ausreichend gut kultiviert und expandiert werden können, so dass eine millionenfache Vermehrung der Zellen möglich ist (BRUDER et al. 1997, COLTER et al. 2000, PITTENGER et al. 1999, PROCKOP 2001). PITTENGER et al. (1999) gelang beispielsweise die Isolierung und Expansion humaner mesenchymaler Stammzellen (hMSC) aus Knochenmarksaspiraten mit anschließender Differenzierung zu Adipozyten, Osteozyten und Chondrozyten. Charakteristisch für diese Stammzellpopulation war neben der Fähigkeit zur Proliferation und dem adhärenten Wachstum die stetige Expression bestimmter Oberflächenmarker wie z.B. SH2, SH3, CD29, CD44. Hingegen konnte keine Expression hämatopoetischer Marker, wie CD14, CD34 oder CD45 nachgewiesen werden. Um die Multipotenz der hMSC zu beweisen und auszuschließen, dass es sich bei den isolierten mesenchymalen Zellen nur um Progenitorzellen handelt, erfolgte eine erneute osteogene, adipogene und chondrogene Differenzierung mithilfe klonaler Zellpopulationen, ausgehend von einer einzigen Zelle. Auf Grundlage der Ergebnisse konnte bewiesen werden, dass es sich bei den isolierten Zellen um multipotente mesenchymale Stammzellen handelt (PITTENGER et al. 1999).

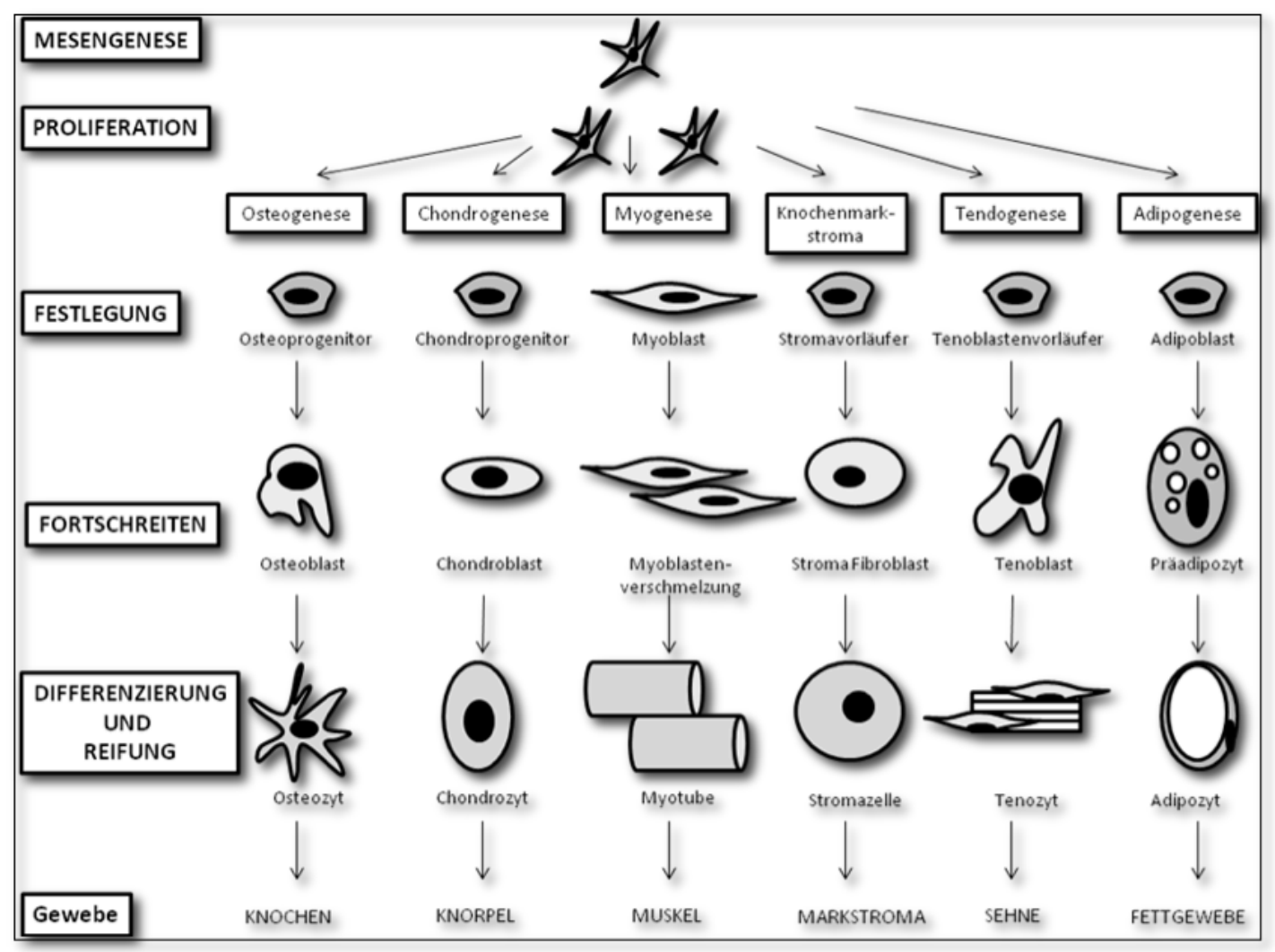

Abb. 2: Schematische Darstellung des Differenzierungspotentials mesenchymaler Stammzellen modifiziert nach CAPLAN und BRUDER (2001), S.260. 
Weitere Studien zeigten, dass isolierte Stammzellen unter definierten In-vitroBedingungen neben Adipozyten, Chondrozyten und Osteozyten in der Lage sind, in Myozyten, neuronale Vorläuferzellen und in die Blutzellbildung unterstützende Stromazellen zu differenzieren (CAPLAN 1991, MAKINO et al. 1999, PITTENGER et al. 1999, WAKITANI et al. 1995, WOODBURY et al. 2000). Abbildung 2 stellt schematisch die Differenzierungsmöglichkeiten einer mesenchymalen Stammzelle dar.

Zur Charakterisierung mesenchymaler Stammzellen kann die Expression verschiedener Oberflächenmarker analysiert werden. Der Oberflächenmarker Stro-1 ist ein trypsin-resistentes Antigen, das auf humanen und murinen Stammzellen identifiziert werden konnte. SIMMONS UND TOROK-STORB (1991) konnten erstmals Stro-1 mittels eines speziellen Antikörpers auf mesenchymalen Zellen im Knochenmark nachweisen. CD133 ist ein Oberflächenmarker für hämatopoetische, mesenchymale und neuronale Stammzellen (D'AQUINO et al. 2007, SHMELKOV et al. 2005, TONDREAU et al. 2005), der erstmalig 1997 entdeckt wurde (YIN et al. 1997). Der Oberflächenmarker CD271, auch bekannt als "low affinity nerve growth factor receptor" (LNGFR) gehört zu der „low affinity Neutrophin Rezeptor-Superfamilie“. Es konnte gezeigt werden, dass er von neuronalen Zellen des zentralen und peripheren Nervensystems exprimiert wird und deren Entwicklung, Überleben und Differenzierung beeinflusst (CASACCIABONNEFIL et al. 1996, CHALAZONITIS et al. 1998, DI STEFANO und JOHNSON 1988, KASHIBA et al. 1995, RUDGE et al. 1994, THOMSON et al. 1988, VROEMEN und WEIDNER 2003). Ebenso konnte in verschiedenen Studien die Expression von CD271 bei mesenchymalen Stammzellen des Knochenmarks nachgewiesen werden (CANEVA et al. 1995, JONES et al. 2002, QUIRICl et al. 2002).

Neben dem Knochenmark gelang die Isolierung adulter mesenchymaler Stammzellen aus weiteren Geweben, wie z.B. Haut, Retina und Nervengewebe (BIANCO et al. 2001, BLAU et al. 2001, DE BARI et al. 2001, FUCHS und SERGE 2000, HARADA et al. 1999, PITTENGER et al. 1999, POTTEN 1998). Dentales Epithel- und Pulpagewebe konnten ebenfalls als mögliche Quelle für die Gewinnung adulter Stammzellen identifiziert werden. Trotz erster viel versprechender Resultate bedarf es aber noch weiterer Forschung (GRONTHOS et al. 2000, SEO et al. 2004). 


\subsection{Dentale Stammzellen und Stammzellmarker}

Die dentalen Stammzellen lassen sich aufgrund ihrer entwicklungsbiologischen Herkunft in ektodermale und ektomesenchymale Stammzellen klassifizieren. Da die ektodermalen Stammzellen nach dem Zahndurchbruch verloren gehen, stellen sie bisher aber keine reale Quelle für die Gewinnung adulter humaner Stammzellen dar (MORSCZECK et al. 2007).

Im Mittelpunkt der bisherigen Forschung stehen die ektomesenchymalen Stammzellen. Aus innen ließen sich in der Vergangenheit verschiedene dentale Stammzelltypen isolieren. Es können die dentalen Pulpa-Stammzellen (DPSCs), (GRONTHOS et al. 2000, D'AQUINO et al. 2007, IOHARA et al. 2006, KERKIS et al. 2006), die „stem cells from human exfoliated deciduous teeth" (SHEDs) (MIURA et al. 2003) die periodontalen Ligament-Stammzellen (PDLSCs) (SEO et al. 2004), die „stem cells from apical papilla“ (SCAPs) und die humanen dentalen Follikel-Vorläuferzellen (HDFCs) (MORSCZECK et al. 2005 a, MORSCZECK et al. 2005 b, MORSCZECK 2006) differenziert werden.

Die DPSCs konnten aus der Pulpa extrahierter Weisheitszähne isoliert werden und ähneln in einigen ihrer Eigenschaften denen der adulten humanen mesenchymalen Stammzellen des Knochenmarks (hMSCs) (GRONTHOS et al. 2000). Ebenso wie die hMSCs sind die DPSCs plastikadhärent und klonogen. Darüber hinaus weisen hMSCs und DPSCs ein ähnliches Expressionsmuster auf. Immunhistochemische Analysen beider Zellpopulationen ergaben, dass sowohl die DPSCs als auch die hMSCs nicht mit hämatopoetischen Markern wie z.B. CD14, CD34 oder CD45 reagieren. Beide Populationen exprimieren Proteine, welche charakteristisch für eine osteogene Differenzierung sind. Es konnte die Expression von Osteocalcin (OCN), alkalischer Phosphatase (AP), Kollagen I (Col1) und Osteonectin beobachtet werden. Beide Stammzellarten bilden unter In-vitro-Bedingungen kalzifiziertes Gewebe, wobei die DPSCs im Gegensatz zu den hMSCs unter definierten In-vivo-Bedingungen in der Lage sind, vaskularisierten Knochen zu bilden (D'AQUINO et al. 2007). Es konnte gezeigt werden, dass hMSCs und DPSCs in verschiedene Phänotypen differenzieren können, beispielsweise in Adipozyten, Osteoblasten, Endothelzellen und neuronale Zellen (D'AQUINO et al. 2007, GRONTHOS et al. 2000, GRONTHOS et al. 2002). Hingegen besitzen nur die DPSCs die Fähigkeit, zu odontoblastenähnlichen Zellen zu differenzieren, welche Dentin/Pulpa-ähnliche Komplexe bilden können (GRONTHOS et al. 2000). Mithilfe des Stro-1-Antikörpers konnten die DPSCs als perivaskuläre Zellen lokalisiert werden (SHI und GRONTHOS 2003). In der Vergangenheit wurden weitere Studien bzgl. der näheren Charakterisierung der DPSCs durchgeführt (D'AQUINO et al. 2007, 
IOHARA et al. 2006, KERKIS et al. 2006). So gelang es IOHARA et al. (2006), aus der Zahnpulpa eine Stammzellpopulation zu isolieren, die besser proliferiert als die initial von GRONTHOS et al. (2000) isolierten DPSCs.

In einer anderen Studie konnte aus der Zahnpulpa exfoliierter Milchzähne eine weitere dentale Stammzellpopulation isoliert werden. Diese Stammzellen wurden als SHEDs („stem cells from exfoliated deciduous teeth”) bezeichnet (MIURA et. al 2003). Sie wiesen eine höhere Proliferationsrate als die DPSCs auf und konnten ebenfalls zu verschiedenen Zelltypen differenzieren. Anhand immunhistochemischer Analysen und „fluorescence-activated cell-sorting“ (FACS) konnte die Expression der mesenchymalen Stammzellmarker Stro-1 und CD146 nachgewiesen werden, wobei zu beobachten war, dass die Stro- $1^{+}$- und CD $146^{+}$-Zellen perivaskulär lokalisiert waren. Ebenso wie die DPSCs wuchsen die SHEDs in vitro adhärent und wiesen eine fibroblastenähnliche Morphologie auf. Nach In-vivo-Transplantation der Zellen in immunsupprimierte Mäuse konnte eine Differenzierung der Zellen in Odontoblasten festgestellt werden. Diese waren in der Lage, dentinähnliche Strukturen zu bilden. Die Entstehung eines PulpaDentin-Komplexes, wie er bei Versuchen mit DPSCs zu beobachten war, blieb jedoch aus (GRONTHOS et al. 2002, MIURA et al. 2003). Darüber hinaus induzierten die transplantierten SHEDs zwar die Knochenneubildung, indem sie Osteoblasten des Wirtstieres rekrutierten, wobei sie selbst aber nicht zu knochenbildenden Zellen differenzierten. Allerdings konnte in vitro ebenso wie bei den DPSCs eine neuronale und adipogene Differenzierung durch entsprechende Expression gewebespezifischer Marker (z.B. Nestin, „glial fibrillary acidic protein“ (GFAP), „peroxisome proliferatoractivated receptor" (PPAR $\gamma$ ), Lipoprotein-Lipase (LPL) nachgewiesen werden (GRONTHOS et al. 2002, KERKIS et al. 2006, MIURA et al. 2003). Anhand einer ÖI-Rot-O-Färbung wurde sichtbar, dass ca. 5\% der SHEDs nach fünf Wochen lipidhaltige Vakuolen aufwiesen und zu Adipozyten differenzierten. Weiterhin konnte im Rahmen des neuronalen Differenzierungsassays eine Veränderung der Zellmorphologie beobachtet werden. Ein Teil der SHEDs verloren ihre fibroblastenähnliche Morphologie und bildeten die für neuronale Zellen typischen multizytoplasmatischen Fortsätze aus (MIURA et al. 2003). Zusammenfassend lässt sich sagen, dass die Pulpa exfoliierter Milchzähne eine vielversprechende Quelle für die komplikationslose Gewinnung und Isolierung postnataler Stammzellen darstellt. Dieses ist allerdings nur im Kindesalter möglich. Daher stellt die effiziente Lagerung und Konservierung der Zellen ein noch zu lösendes Problem dar.

Neben den DPSCs und den SHEDs konnte aus dem Zahnhalteapparat extrahierter Zähne eine weitere Stammzellpopulation isoliert werden. Diese Stammzellen wurden als periodontale Ligament-Stammzellen (PDLSCs) bezeichnet; sie sind ebenso wie die 
DPSCs klonogen und plastikadhärent, wiesen aber eine höhere Proliferationsrate als die DPSCs auf (SEO et al. 2004). Die Zellen wurden aus dem parodontalen Ligament (PDL) extrahierter impaktierter Weisheitszähne junger Erwachsener isoliert. Die PDLSCs exprimierten ebenso wie die hMSCs und DPSCs die mesenchymalen Stammzellmarker Stro-1 und CD146 (GRONTHOS et al. 2000, GRONTHOS et al. 2002, SEO et al. 2004, SHI und GRONTHOS 2003). Darüber hinaus konnten die PDLSCs unter entsprechend definierten In-vitro-Bedingungen ebenfalls zu Adipozyten differenziert werden. Nach 3-wöchiger Inkubation konnten Öl-Rot-O-positive, lipidgefüllte Fettzellen beobachtet werden. Diese Beobachtung korrelierte mit der Hochregulation von PPAR $\gamma$ und LPL (SEO et al. 2004). Die PDLSCs zeigten unter In-vitroBedingungen Mineralisationspotential und exprimierten Zementoblasten- bzw. Osteoblasten-assoziierte Marker, z.B. alkalische Phosphatase, „matrix extracellular phosphoglycoprotein“ (MEPE), Bone Sialoprotein (BSP) oder Osteocalcin. Die PDLSCs bildeten allerdings weniger kalzifizierte Nodules als die DPSCs. Nach Transplantation von PDLSCs in immunsupprimierte Mäuse war diese Stammzellpopulation in der Lage, eine Zement- bzw. PDL-ähnliche Struktur zu bilden. Es konnte keine Knochen- oder Dentinbildung beobachtet werden, wie sie in In-vivo-Versuchen mit hMSCs, DPSCs oder SHEDs nachgewiesen wurde (GRONTHOS et al. 2000, GRONTHOS et al. 2002, MIURA et al. 2003, SEO et al. 2004).

Eine weitere Quelle für die Gewinnung adulter Stammzellen stellt der dentale Follikel dar. Der dentale Follikel ist ein Vorläufergewebe des Zahnhalteapparates, umgibt den Zahnkeim und enthält Zellen, die später den Alveolarknochen, das parodontale Ligament und den Zahnzement bilden. In verschiedenen Studien konnten humane dentale Follikel-Vorläuferzellen (HDFCs) aus Follikeln extrahierter Weisheitszähne isoliert werden (KEMOUN et al. 2007, MORSCZECK et al. 2005 a, MORSCZECK et al. 2005 b, MORSCZECK 2006). Die HDFCs sind, ebenso wie die mesenchymalen Stammzellen des Knochenmarks und die DPSCs, plastikadhärent und klonogen. Die HDFCs exprimierten den neurogenen Marker Nestin ebenso wie verschiedene osteogene Marker. Es konnte eine Zunahme der Expression von Osteocalcin und „bone morphogenic protein 2" (BMP-2) während der osteogenen Differenzierungsversuche nachgewiesen werden, während die Expression von BSP und „core binding factor 1" (Cbfa1) abfiel bzw. unverändert blieb (MORSCZECK et al. 2005 a, MORSCZECK et al. 2005 b). HDFCs konnten sowohl unter In-vitro- und In-vivo-Bedingungen zu osteogenen Zellen differenziert werden. Allerdings waren sie nach Transplantation in immunsupprimierte Mäuse nicht in der Lage, Zement oder Knochen zu bilden (MORSCZECK et al. 2005 a, MORSCZECK et al. 2005 b). Des Weiteren konnte gezeigt werden, dass die HDFCs über ein multipotentes Differenzierungspotential verfügen. Neben der Differenzierung 
zu Osteoblasten gelang die Differenzierung zu Chondrozyten und Adipozyten im Rahmen entsprechender Differenzierungsassays. Nach 21 Tagen war nach osteogener Differenzierung der HDFCs die Bildung kalzifizierter Nodules (Alizarin-Rot-Färbung) zu beobachten. Die chondrogene Differenzierung der Zellen konnte histologisch anhand der Proteoglycan-Synthese (Alizarin-Blau-Färbung) und der Expression von Kollagen II nachgewiesen werden. Nach der 21-tägigen Inkubation der HDFCs in einem adipogenen Differenzierungsmedium waren die Bildung von Öl-Rot-O-positiven Lipidvakuolen sowie die Expression von PPAR $\gamma$ evident. Darüber hinaus exprimierten die HDFCs ebenso wie die HMSCs und DPSCs den mesenchymalen Stammzellmarker Stro-1 und waren CD45 negativ (KEMOUN et al. 2007).

Eine weitere Stammzellpopulation sind die SCAPs („stem cells from apical papilla“), welche aus dem Gewebe der apikalen Papille im Bereich des Foramens der Wurzelspitze isoliert werden konnten (SONOYAMA et al. 2006). In verschiedenen Differenzierungsassays zum Nachweis der Multipotenz gelang u.a. die Differenzierung der SCAPs zu odonto- und osteoblastenähnlichen Zellen, welche kalzifizierte Matrix produzierten. Nach fünf Wochen waren Öl-Rot-O-positiv gefärbte Fettzellen zu beobachten. Des Weiteren exprimierten die SCAPs nach neurogener Differenzierung entsprechend spezifische Marker, beispielsweise Nestin oder $\beta$ III-Tubulin (SONOYAMA et al. 2008). Im Rahmen eines In-vivo-Versuches konnte mit transplantierten SCAPs und PDLSCs in Verbindung mit einem Trägermaterial aus Hydroxylapatit/Tricalciumphosphat ein zahnwurzelähnliches Gewebe mit angrenzendem PDL gebildet werden. Es gelang die Insertion dieser zahnwurzelähnlichen Konstruktion in den Kieferknochen eines Minischweins und die anschließende Applikation einer Keramikkrone (SONOYAMA et al. 2006). Diese Forschungsergebnisse lassen erste Schritte bzgl. einer neuen Form der Zahnimplantation erhoffen und bedürfen weiterer Untersuchungen.

In einem Großteil der bisher durchgeführten Studien wurden die DPSCs aus der Pulpa extrahierter Weisheitszähne adulter Patienten gewonnen (BATOULI et al. 2003, GRONTHOS et al. 2000, GRONTHOS et al. 2002, PAPACCIO et al. 2006, YAMADA et al. 2006). Das Wurzelwachstum der entsprechenden Zähne war bereits abgeschlossen. Es existieren jedoch nur vereinzelt Studien bzgl. der Charakterisierung von DPSCs, die aus der Pulpa von Zähnen mit noch nicht abgeschlossenem Wurzelwachstum, sogenannten Zahnkeimen, gewonnen wurden. TAKEDA et al. (2008) charakterisierten eine Population von DPSCs, welche aus der Pulpa von Zahnkeimen isoliert werden konnten. Im Rahmen dieser Studie wurden das Proliferationsverhalten, das Differenzierungspotential und die Genexpression dieser Zahnkeimzellen analysiert. Nach osteogener und odontogener In-vitro-Differenzierung konnten nach 15 Ta- 
gen AP-positive Zellen und kalzifizierte Matrix beobachtet werden. Nach 28 Tagen adipogener Differenzierung wurden lipidhaltige Fettzellen anhand einer Öl-Rot-O-Färbung nachgewiesen, die Expression von PPAR $\gamma$ und LPL war hingegen negativ. Die Expression neuronaler Marker wie Nestin und $\beta$ III-Tubulin war nach 18-tägiger Differenzierung evident. In vivo bildeten die Zahnkeimzellen nach Transplantation in immunsupprimierte Mäuse Dentin-Pulpa-ähnliche Komplexe. Die Studie von TAKEDA et al. (2008) zeigte ebenfalls, dass sowohl die DPSCs als auch die Zahnkeimzellen nach langfristiger Kultivierung über 30 Passagen ihre Fähigkeit zur Differenzierung verloren hatten. Diese Resultate deuten an, dass die charakteristischen Eigenschaften der Zahnkeimzellen denen der DPSCs ähneln und sie über ein ähnliches Differenzierungspotential verfügen.

Zur Identifizierung und Isolierung der unterschiedlichen Stammzellpopulationen werden Stammzellmarker verwendet. Diese werden fast ausschließlich von undifferenzierten Zellen exprimiert oder fungieren als Oberflächenmarker zur Isolierung von Stammzellen. Ein wichtiger dentaler Stammzellmarker ist Stro-1, der von den mesenchymalen Stammzellen des Knochenmarks exprimiert wird. Es konnte gezeigt werden, dass Stro-1 von den DPSCs, den SHEDs, den HDFCs und den PDLSCs exprimiert wird (D'AQUINO et al. 2007, GRONTHOS et al 2000, JO et al. 2007, KEMOUN et al. 2007, MIURA et al. 2003, SEO et al. 2004, SHI und GRONTHOS 2003, SIMMONS und TOROK-STORB 1991). Des Weiteren konnte festgestellt werden, dass die Expression des perivaskulären Oberflächenmarkers CD146 bei HMSCs, DPSCs, SHEDs und PDLSCs evident ist (GRONTHOS et al. 2003, MIURA et al. 2004, SEO et al. 2004, SHI und GRONTHOS 2003). Im Gegensatz hierzu kommt es bei dem Großteil der dentalen Stammzellpopulationen nicht zur Expression der hämatopoetischen Oberflächenmarker CD14, CD45 und CD34 (SHI et al. 2005). Eine Ausnahme stellt die von D'AQUINO et al. (2007) isolierte Stammzellpopulation dar, welche neben CD34 auch den Stammzellmarker CD133 exprimiert. Es existieren in der Literatur derzeit nur unzureichende Angaben bzgl. der Expression von CD133 und CD271 auf humanen dentalen Stammzellen. Die Ergebnisse vergangener Studien lassen darauf schließen, dass unterschiedliche Stammzelltypen in der Pulpa existieren, die sich von den von GRONTHOS et al. (2000) beschriebenen Stammzellen unterscheiden (D'AQUINO et al. 2007, WADDINGTON et al. 2009). Im Rahmen dieses Versuches erfolgte die Isolierung und Sortierung der Zahnkeimzellen mit den Stammzellmarkern Stro-1, CD271 und CD133. 


\subsection{Osteogenese}

Die Osteogenese beschreibt die Bildung von Knochengewebe, welches sich aus Knochenzellen und extrazellulärer Knochenmatrix zusammensetzt. Die extrazelluläre Matrix besteht aus organischen und anorganischen Bestandteilen. Die anorganischen Substanzen sind in die organische Knochengrundsubstanz eingelagert und setzen sich hauptsächlich aus Hydroxylapatitkristallen, Magnesium, Kalium, Chlor, Eisen und Karbonat zusammen. Der organische Anteil der extrazellulären Knochenmatrix besteht zu 90\% aus Kollagen Typ I (YOUNG 2003), das von Osteoblasten und Fibroblasten synthetisiert wird (ROSSERT et al. 2000). Der restliche Anteil setzt sich aus nichtkollagenen Proteinen zusammen, zu welchen Osteopontin, Osteonectin, Osteocalcin, Sialoprotein, Phosphoproteine, Glykoproteine, Proteoglykane, Albumin und andere Proteine zählen. Die Knochenneubildung geht von den Osteoblasten aus, welche sich aus pluripotenten mesenchymalen Stammzellen entwickeln (BHARGAVA et al.1988, BRUDER et al. 1995). Die Osteoblasten sind an der Synthese und Mineralisierung der organischen Matrix beteiligt.

Es können in diesem Zusammenhang drei Phasen unterschieden werden (ABE et al. 1993, COLLIN et al. 1992):

$>$ Aktive Proliferation und Synthese von Kollagenen

$>$ Extrazelluläre Matrixreifung und Expression von alkalischer Phosphatase

$>$ Mineralisierung der Matrix.

Der Differenzierungsprozess der Osteoblasten in Zusammenhang mit der zeitlichen Abfolge der Expression bestimmter Markergene ist in Abbildung 3 dargestellt (OWEN et al. 1990).

Aus Abbildung 3 geht hervor, dass Kollagen Typ I eines der ersten Markergene der osteogenen Differenzierung darstellt. Die alkalische Phosphatase wird zu Beginn der extrazellulären Matrixreifung transient exprimiert, während das Osteocalcin zeitlich erst nach dem Glykoprotein Osteopontin auftritt. Osteocalcin ist ein Markergen für reife Osteoblasten und wird während der Phase der Matrixmineralisierung exprimiert (OWEN et al. 1990). Die Regulation der Osteocalcinexpression erfolgt offenbar über den osteogenen „core binding factor 1“ (Cbfa1), einen essentiellen Transkripitionsfaktor der Osteoblastendifferenzierung (RODAN 1997). 


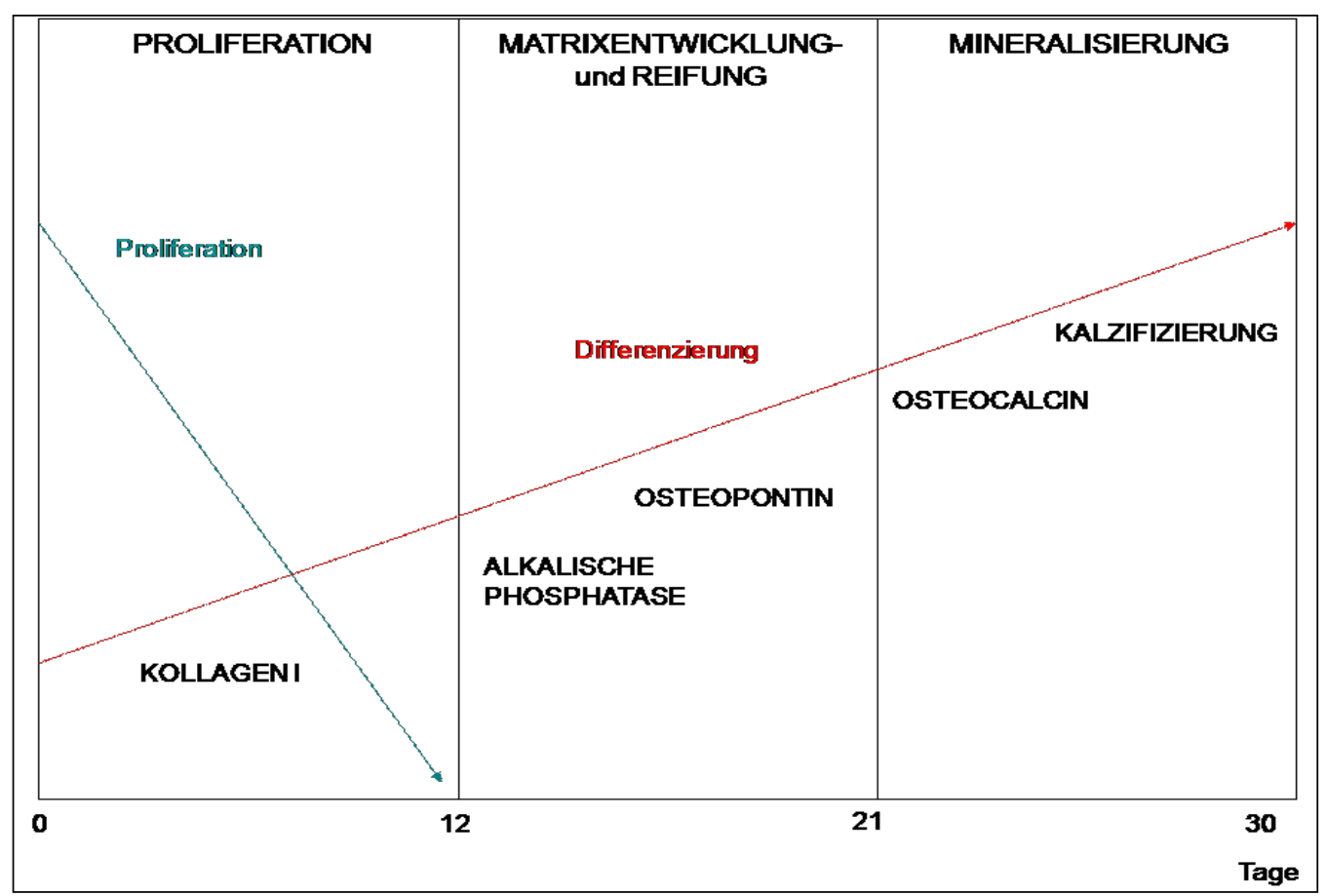

Abb. 3: Schematische Darstellung der Genexpression des osteogenen Differenzierungsprozesses modifiziert nach OWEN et al. (1990), S.429.

Die Entwicklung der Knochenzellen erfolgt dabei über eine Reihe von Vorläuferzellen (AUBIN et al. 1993, AUBIN et al 1995, CAPLAN und BOYAN 1994). Daher lassen sich verschiedene Stadien der Differenzierung unterscheiden, welche durch die Expression verschiedener Markergene gekennzeichnet sind und anhand spezifischer Antikörper erkannt werden können (BRUDER et al. 1998, JOYNER et al. 1997). Die undifferenzierten Stammzellen entwickeln sich, wie in Abbildung 4 dargestellt, über Osteoprogenitorzellen, Präosteoblasten und Osteoblasten zu Osteozyten oder "lining-cells“. Die Differenzierungskaskade wird in vivo und in vitro durch eine Sekretionsabfolge unterschiedlicher Proteine gesteuert. Das Stadium der Osteoprogenitorzellen und Präosteoblasten zeichnet sich durch eine hohe Zellteilungsaktivität aus. Im Anschluss an die Osteoblastenproliferation erfolgt die Differenzierung der Zellen. Die mitotisch aktiven Präosteoblasten differenzieren zu Osteoblasten, welche sämtliche zur Knochenbildung nötigen Matrixkomponenten synthetisieren und sezernieren. Etwa 10-20\% der Osteoblasten werden im Rahmen des Mineralisierungsprozesses in der Knochenmatrix eingemauert und entwickeln sich zu Osteozyten. Darüber hinaus differenzieren einige Osteoblasten zu sogenannten „lining-cells“, deren Funktion noch nicht definiert werden konnte. Es wird diskutiert, ob sie eine Rolle in der Ernährung der Osteozyten spielen (MILLER 1987) oder am Knochenumbau durch die Aktivierung von Osteoklasten beteiligt sind (PARFITT 1994). Der Großteil der Osteoblasten (65\%) unterliegt im Anschluss an die Osteogenese dem programmierten Zelltod (Apoptose) (JILKA et al. 1998, MANGOLAS 2000). 


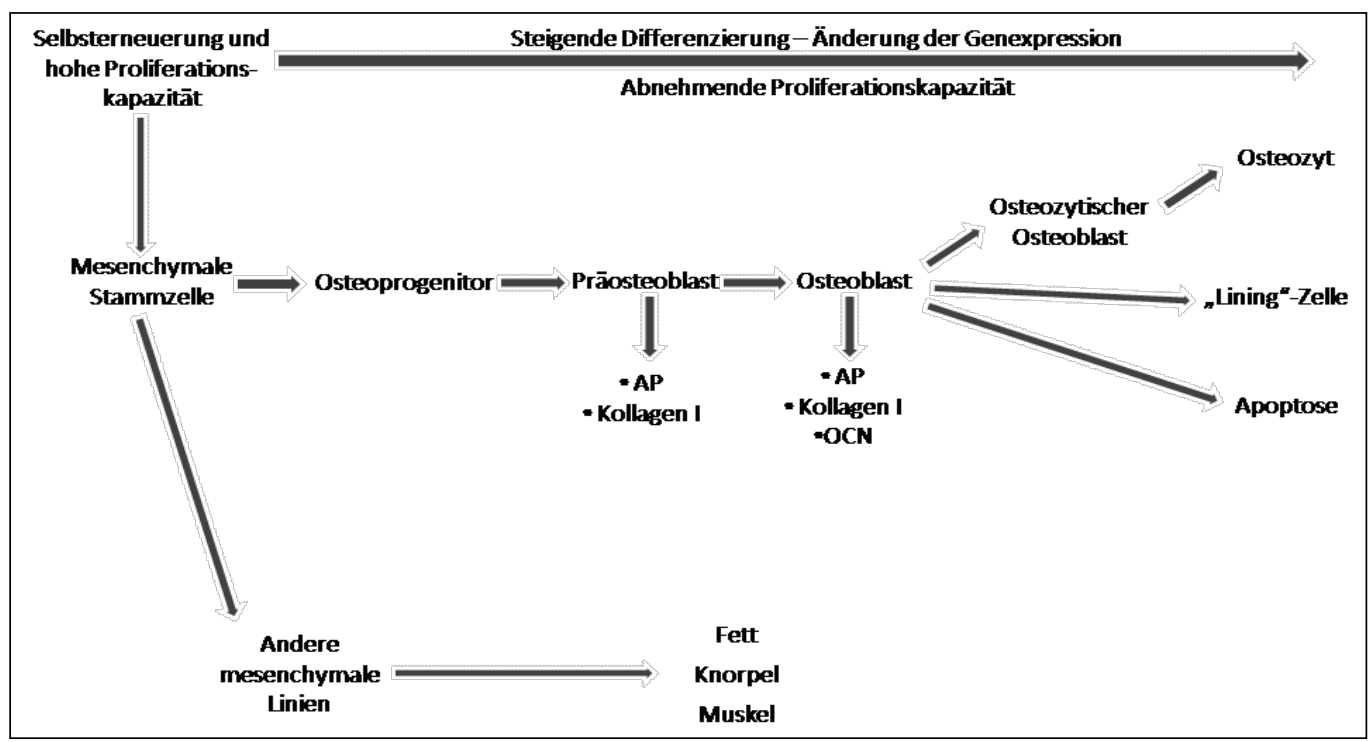

Abb. 4: Schematischer Ablauf der osteogenen Differenzierung in vitro. Vereinfachte Darstellung einzelner Entwicklungsstadien mit entsprechender Markerexpression der osteogenen Differenzierung ausgehend von einer mesenchymalen Stammzelle. Die Darstellung ist modifiziert nach AUBIN (2001), S.83 $(\mathrm{AP}=$ alkalische Phosphatase, $\mathrm{OCN}=$ Osteocalcin $)$.

\subsection{Chondrogenese}

Die Chondrogenese beschreibt die Bildung des Knorpelgewebes, welches sich aus Knorpelzellen (Chondrozyten) und einer charakteristischen Extrazellularmatrix zusammensetzt. Es lassen sich je nach Zusammensetzung dieser Bestandteile drei verschiedene Knorpelarten unterscheiden: Faserknorpel, elastischer Knorpel und hyaliner Knorpel. Der Faserknorpel besteht aus miteinander verflochtenen Faserbündeln aus Kollagen, die ihm eine besondere Zugfestigkeit verleihen. Er befindet sich im Bereich der Menisken, der Symphyse und der Bandscheiben (SCHIEBLER und SCHMIDT 1999 b). Den elastischen Knorpel findet man im äußeren Gehörgang und der Ohrmuschel. Neben kollagenen Fasern enthält die Extrazellularmatrix dieses Knorpeltyps noch elastische Fasern (SCHIEBLER und SCHMIDT 1999 b). Die 3. Knorpelart stellt der hyaline Knorpel dar, welcher vor allem auf den artikulierenden Flächen der Gelenke zu finden ist. Die Herstellung hyalinen Knorpels stellt einen großen Fortschritt für die Therapie von Gelenkknorpeldefekten dar und soll daher im Folgenden näher beschrieben werden. Der hyaline Knorpel setzt sich aus extrazellulärer Matrix und Chondrozyten $(1-10 \%)$ zusammen (CARNEY und MUIR 1988). Die Chondrozyten sind in der Extrazellularmatrix in speziellen Kapseln (Chondronen) eingebettet und sind sowohl für die Synthese als auch für den Abbau der Extrazellularmatrix verantwortlich. Die extrazelluläre Matrix besteht neben Wasser und Ionen (70-80\%) hauptsächlich aus den Kollagentypen II, IX und XI sowie aus Glykoproteinen und Proteoglykanen (z.B. Aggrecan, 
Chondroadherin) (BARRY et al. 2001, EYRE 2002, LEFEBVRE und SMITS 2005, MÅNSSON et al. 2001, MANKIN und TRASHER 1975, MENDLER et al. 1989). Die Entwicklung des Knorpelgewebes ist ein komplexer Prozess, der mit der Proliferation und Aggregation mesenchymaler Stammzellen beginnt und durch mesenchymalepitheliale Zellinteraktionen reguliert wird (GOLDRING et al. 2006, HALL und MIYAKE 2000, TACCHETTI et al. 1992, TUAN 2004). Im Rahmen der Chondrogenese differenzieren die mesenchymalen Stammzellen über mehrere Zellstadien zu reifen hypertrophen Chondrozyten. Die einzelnen Stadien sind durch die Synthese verschiedener Proteine der Extrazellularmatrix sowie durch die Expression regulatorischer Marker gekennzeichnet (LEFEBVRE und SMITS 2005). Je nach Reifegrad synthetisieren die Chondroprogenitorzellen zunächst Kollagen Typ II, später auch Kollagen Typ IX, XI und Aggrecan. Abbildung 5 zeigt eine vereinfachte Übersicht der einzelnen Differenzierungsstadien, der extrazellulären Proteine und der regulatorischen Marker. Der Transkriptionsfaktor Sox9 ist auf regulatorischer Ebene für die Expression der Gene für Kollagen Typ II, XI und Aggrecan verantwortlich (BRIDGEWATER et al. 1998, LEFEBVRE und SMITS 2005, LIU et al. 2000, SEKIYA et al. 2000). Er wird vom Zustand der undifferenzierten mesenchymalen Zelle bis hin zum säulenförmigen Chondroblasten exprimiert (LEFEBVRE und SMITS 2005).

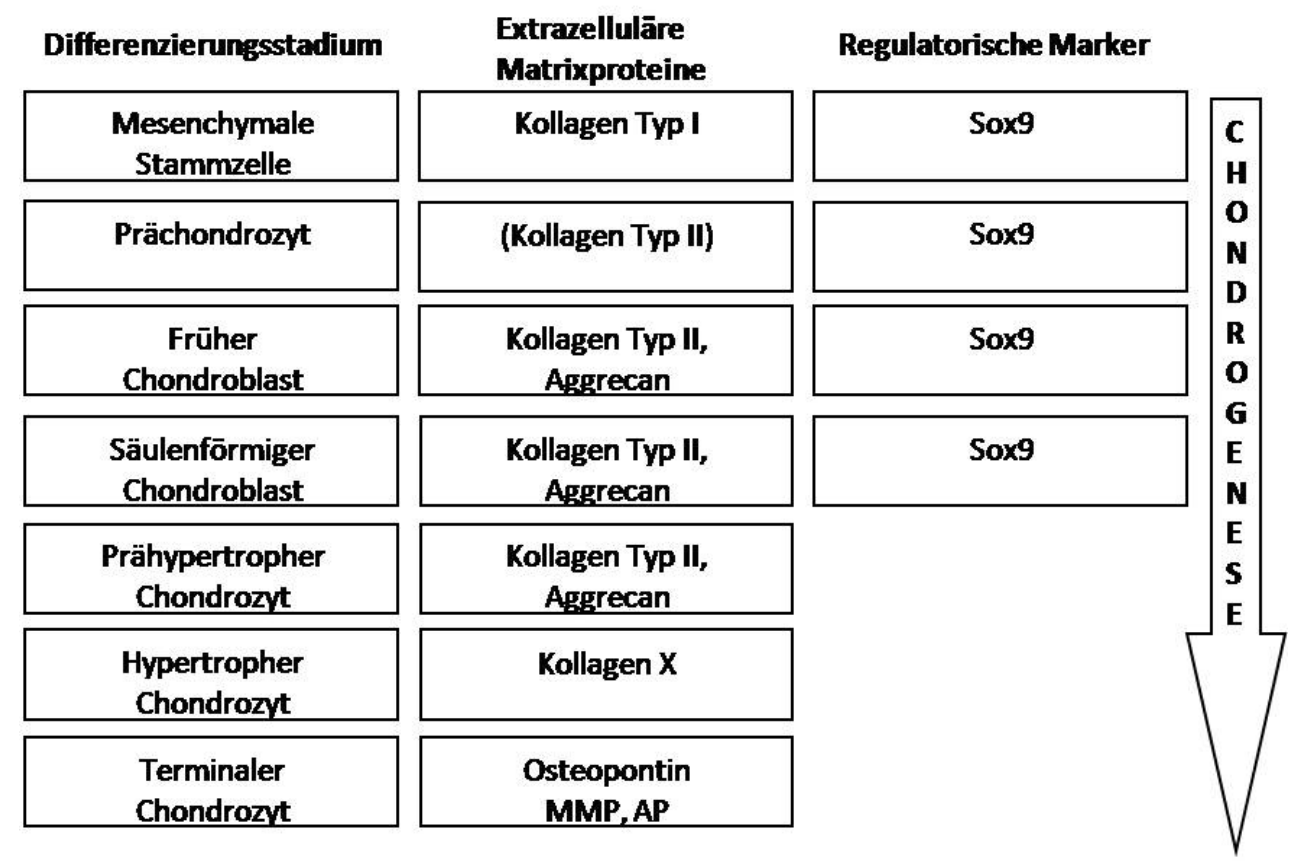

Abb. 5: Vereinfachte Darstellung einzelner Phasen der Chondrogenese unter Einbeziehung der verschiedenen Differenzierungsstadien der Zellen, der entsprechenden Matrixproteinsynthese und der regulatorischen Marker. Die Darstellung ist modifiziert nach LEFEBVRE UND SMITS (2005), S.202. $(\mathrm{MMP}=$ Matrixmetalloproteinase $13, \mathrm{AP}=$ alkalische Phosphatase, Sox9 $=$ SRY (sex determining region Y)-box 9). 


\subsection{Adipogenese}

Die Adipogenese beschreibt die Bildung des Fettgewebes, welches sich aus Fettzellen (Adipozyten), Bindegewebszellen (Fibroblasten), adipozytären Vorläuferzellen (Präadipozyten), Immunzellen, sowie Endothel- und Blutzellen zusammensetzt. Adipozyten entwickeln sich, ebenso wie Knochen- oder Knorpelzellen, aus multipotenten mesenchymalen Stammzellen. Die Adipogenese lässt sich in zwei Entwicklungsphasen unterteilen. Die 1. Phase ist definiert als „Determination“, die 2. Phase als „terminale Differenzierung" (ROSEN und MACDOUGALD 2006). Im Rahmen der Determination wird festgelegt, dass sich die multipotente Vorläuferzelle zu einem Adipozyten entwickelt. Die Differenzierung in andere Zellinien, z.B. Knochen oder Knorpel, ist somit nicht mehr möglich. Es entsteht als frühe Vorläuferzelle der Adipoblast, welcher sich zu einem Präadipozyten weiterentwickelt. Der Präadipozyt ist noch teilungsfähig und exprimiert bereits eine Reihe funktioneller Proteine (z.B. LPL), insbesondere verschiedene Transkriptionsfaktoren (z.B. PPAR $\gamma$ ) (BOONE et al. 2000). Diese Transkriptionsfaktoren steuern die Expression adipozytenspezifischer Gene, was zur „terminalen Differenzierung" führt. Im Rahmen dieser Phase bildet sich die typische Morphologie des Adipozyten aus. Durch die zunehmende Lipidakkumulation wird das Zytoplasma des Adipozyten fast vollständig von einer großen Lipidvakuole ausgefüllt, wodurch der Zellkern in die Peripherie des verbliebenen Zytoplasmas verdrängt wird. Der Transkriptionsfaktor PPAR $\gamma$ kommt fast ausschließlich im Fettgewebe vor und gilt als Hauptregulator der Adipogenese (TONTONOZ et al. 1994 a, TONTONOZ et al. 1994 b). Abbildung 6 zeigt schematisch den Ablauf der adipogenen Differenzierung muriner Stammzellen in vitro. Die adipogene Differenzierung wird durch die Determination der multipotenten mesenchymalen Stammzelle (MSC) in die adipogene Zelllinie eingeleitet.

Die Mechanismen für die Initiation der Adipogenese sind bisher nicht bekannt (ROSEN et al. 2000). Der entstandene Adipoblast proliferiert während der exponentiellen Wachstumsphase und durchläuft anschließend eine Phase des Wachstumsstops. Es folgen ein bis zwei weitere Mitosen der entstandenen Präadipozyten (klonale Expansion) und es kommt zur Expression der frühen Differenzierungsmarker wie z.B. PPAR $\gamma$ und LPL. Nach Eintritt des 2. permanenten Wachstumsstops differenziert die Zelle unter sukzessiver Expression der entsprechenden Marker und Akkumulation von Triglyzeriden zu unreifen und nachfolgend reifen Adipozyten (frühe bzw. späte Differenzierung). In humanen Zellmodellen wird die Phase der klonalen Expansion nicht beobachtet und die Präadipozyten können ohne Zellteilung zu Adipozyten differenzieren (ENTENMANN und HAUNER 1996). 


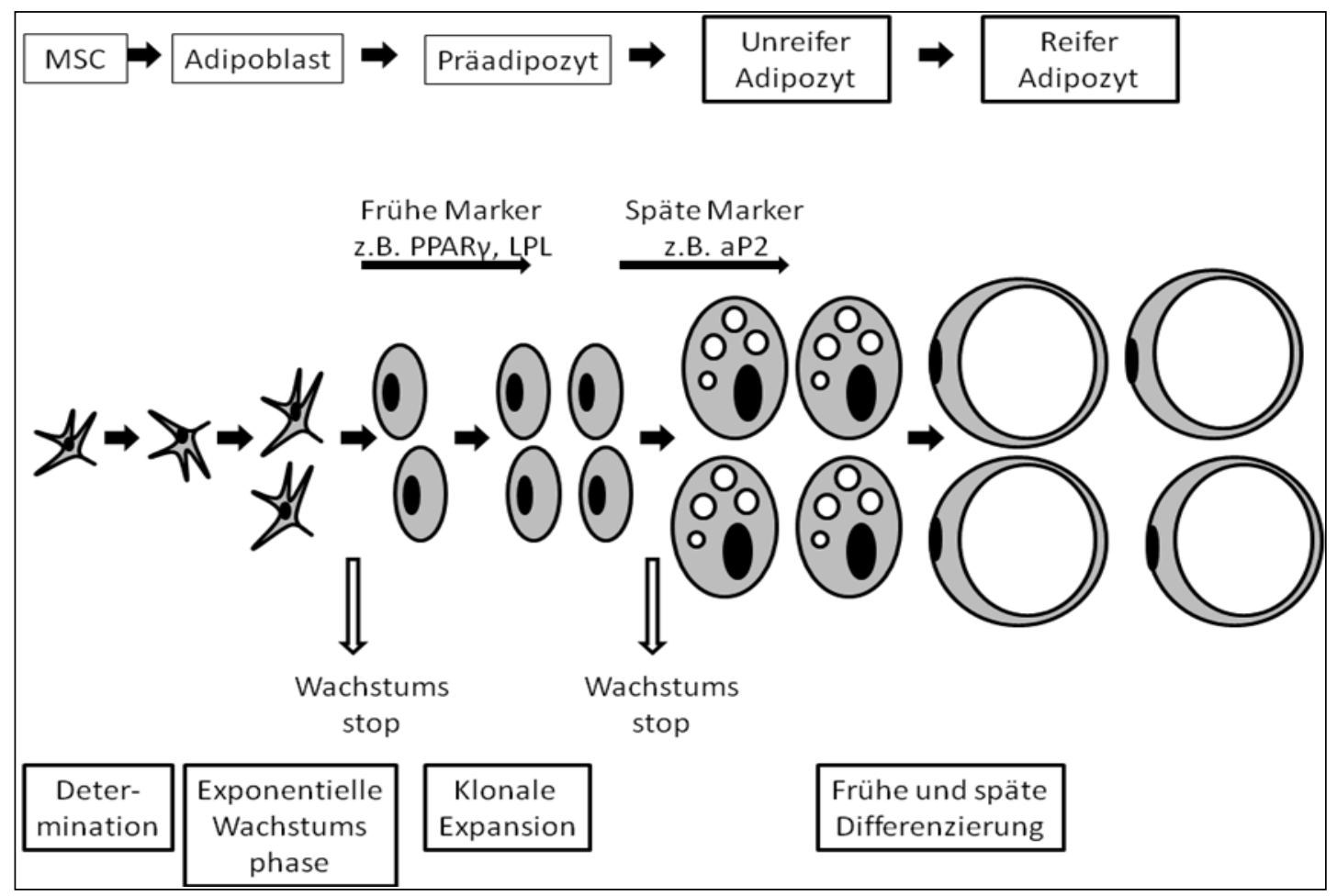

Abb. 6: Schematischer Ablauf der adipogenen Differenzierung muriner Stammzellen in vitro. Die Abbildung wurde modifiziert nach BOONE et al. (2000), S.328. (LPL = Lipoprotein Lipase, PPAR $\gamma=$ „peroxisome proliferator-activated receptor“, aP2 = „adipocyte protein 2“/“fatty acid binding protein 4“ = FABP4). 


\section{Material und Methoden}

\subsection{Zellen und Zellkulturen}

Die verwendeten Zahnkeime für diese Arbeit stammten aus der Abteilung für Mund-, Kiefer- und Gesichtschirurgie der Universitäts-Medizin-Göttingen (UMG). Im Rahmen operativer Eingriffe entfernte und nicht mehr benötigte Zahnkeime dienten als Ausgangsmaterial für Primärkulturen. Bei den Zahnkeimen handelte es sich um retinierte oder überzählige Zähne, die bei den Kindern aus kieferorthopädischen Gründen entfernt werden mussten und die in der Regel verworfen werden. Eine schriftliche Einverständniserklärung der Patienten bzw. derer Eltern zur Verwendung des Materials für Forschungszwecke liegt in allen Fällen vor. Die Studie wurde von der Ethikkommission der UMG genehmigt (positives Ethikvotum 15/10/01 und 31/4/11). Die Versuche wurden mit den im Anhang aufgeführten Materialien durchgeführt.

Alle im Folgenden aufgeführten Arbeiten mit Zellkulturen sowie die Herstellung der verwendeten Lösungen wurden unter sterilen Bedingungen (Strerilbank Biohazard Cleanair En12469, JA Woerden) durchgeführt. Vor jedem Mediumwechsel wurden die Zellkulturen mikroskopisch (Mikroskop Carl Zeiss Vision $\mathrm{GmbH}$, Hallbergmoos) auf bakterielle und fungizide Kontaminationen untersucht. Die Kultivierung der Zellen erfolgte im Brutschrank (Sanyo Electric Biomedical CO., Ltd, Japan) unter kontrollierten, einheitlichen Bedingungen bei einer Temperatur von $37^{\circ} \mathrm{C}$, einem Kohlenstoffdioxidanteil von $5 \%$ und $95 \%$ Luftfeuchtigkeit.

Aus den verwendeten Zahnkeimen wurde das Weichgewebe der Pulpa entnommen, in kleine Stückchen zerteilt und in einer Petrischale $\left(58 \mathrm{~cm}^{2}\right.$, Sarstedt, Sarstedt AG \& CO, Nümbrecht) mit $15 \mathrm{ml}$ Nährmedium (DMEM, 10\% FKS, 1\% Penicillin-Streptomycin) kultiviert. Die Proliferation der dem Zahnkeim entwachsenen Zellen wurde unter dem Mikroskop beobachtet. Nachdem die aus dem Zahnkeim herausgewachsenen Zellen in der Schale einen fast konfluenten Zellrasen gebildet hatten, wurden Gewebestückchen in weitere Petrischalen umgesetzt. Die verbliebenen Zellen, die sogenannte Primärkultur, wurden zur weiteren Proliferation trypsiniert, passagiert, gezählt und möglichst gleichmäßig auf Zellkulturflaschen $\left(75 \mathrm{~cm}^{2}\right.$, Greiner, Bio-One $\mathrm{GmbH}$, Solingen) verteilt. Ein Austausch des Nährmediums erfolgte alle zwei bis drei Tage.

Das Passagieren der Zellen erfolgte bei Erreichen eines fast konfluenten Wachstums. Das Medium wurde unter Vakuum abgesaugt und die Zellen anschließend mit vorgewärmten PBS $\left(37^{\circ} \mathrm{C}\right.$ ) gewaschen. Daraufhin wurden $2 \mathrm{ml}$ Trypsin (auf $37^{\circ} \mathrm{C}$ temperiert) zugegeben und eine 5-minütige Inkubation im Brutschrank durchgeführt. Je nach 
Ablösungszustand der Zellen wurden gegebenenfalls noch am Boden der Zellkulturflasche adhärente Zellen durch leichtes Klopfen und Bewegen der Flasche gelöst. Nach Mobilisation der Zellen wurde das Trypsin mit $8 \mathrm{ml}$ DMEM inaktiviert und die Zellsuspension in ein Zentrifugenröhrchen überführt. Die Zellzahl wurde mit Hilfe des Zellzählgerätes CASY (Schärfe System/Innovatis, Reutlingen) ermittelt, die in der Suspension enthaltenen Zellen für eine Dauer von fünf Minuten bei $250 \times \mathrm{g}$ zentrifugiert und der Überstand verworfen. Das verbliebene Zellpellet wurde, je nach Zellzahl, in einer entsprechenden Menge Wachstumsmedium aufgenommen und so aufgeteilt, dass maximal 700.000 Zellen in eine Zellkulturflasche $\left(75 \mathrm{~cm}^{2}\right)$ ausplattiert wurden. Nach mikroskopischer Kontrolle wurden die passagierten Zellen im Brutschrank unter standardisierten Bedingungen weiter kultiviert. Eine Passage wurde charakterisiert durch das Ablösen einer adhärenten Kultur (z.B. durch Trypsinierung) gefolgt von einer weiteren Kultivierung der Zellen in geringeren Konzentrationen. Das Passagieren der Zellen erfolgte vor Erreichen der Konfluenz, um eine vorzeitige Differenzierung der proliferierenden Kulturen zu vermeiden.

\subsection{Zellzählung}

Das Zählen der Zellen erfolgte nach dem Passagieren bzw. dem Ernten der Zellen mit Hilfe des Zellzählgeräts CASY (Schärfe System/Innovatis, Reutlingen). Hierbei wurde die zu messende Zellsuspension gut vermischt und eine Probe entnommen. Diese wurde in einem Verhältnis von 1:100 mit der isotonen Pufferlösung (CASYton) verdünnt. Dementsprechend wurde zu $10 \mathrm{ml}$ Pufferlösung ein Volumen von $100 \mu \mathrm{l}$ Zellsuspension hinzugegeben und nochmals gut vermischt. Im Anschluss erfolgte die Zellzählung durch das Zellzählgerät. Die zu zählenden Zellen werden hierbei in eine Messkapillare gesaugt, an die eine elektrische Spannung angelegt ist. Durch den Zelleintritt in die Messkapillare kommt es zu einer Widerstandsänderung, welche einen elektrischen Impuls hervorruft. Die Anzahl der Impulse entspricht der Zellzahl. Dieses Widerstandsmessprinzip wird mit dem Verfahren der Pulsflächenanalyse kombiniert, wobei die jeweilige Pulsfläche proportional zum Zellvolumen ist. Daher erfolgt neben der Zellzahlbestimmung eine Darstellung der Größenverteilung der Zellen. Je nach Zellgröße werden individuelle Impulse verursacht, wodurch eine Differenzierung verschiedener Zellpopulationen sowie die Abgrenzung vitaler von devitalen Zellen möglich sind. Aufgrund der defekten und durchlässigen Zellmembranen devitaler Zellen werden diese anhand der Größe ihres Zellkerns bestimmt und somit kleiner dargestellt als vitale Zellen mit intakter Zellmembran. Daher ist es möglich die Anzahl der lebenden Zellen für die Differenzierungsassays zu bestimmen. 


\subsection{Zellsortierung mit Magnet-Beads (MACS)}

Die Zellsortierung mit magnetischen Partikeln „magnetic-activated cell-sorting“ (MACS) wird bei der Isolierung bestimmter Zellpopulationen angewendet. Im Versuchsablauf wurden die kultivierten Zahnkeimzellen anhand spezifischer magnetgekoppelter Antikörper (CD133, CD271, Stro-1) selektiert. Die verwendeten Antikörper binden an spezifische Oberflächenstrukturen der Zellen, wodurch diese über die Antikörper mit den magnetischen MicroBeads verbunden werden. Die Selektion der an die MicroBeads gekoppelten Zellen aus dem Zellgemisch fand beim Durchfluss der Mischpopulation durch ein Magnetfeld statt. Die verwendeten Zahnkeimzellen wurden für die Selektion vorbereitet, indem sie vor allen Sortierungen mit $2 \mathrm{ml}$ PBS gewaschen wurden. Nach dem Trypsinieren wurde die Zellzahl im CASY bestimmt. Danach wurde die Zellsuspension mit $250 \times \mathrm{g}$ zentrifugiert und der Überstand abgesaugt. Die verbliebenen Zellen wurden mit 2 ml PBS gewaschen, zentrifugiert und der Überstand erneut verworfen. Die Markierung dieser Zellen erfolgte durch die Zugabe der verwendeten Antikörper und entsprechende Inkubation (Markierungsprotokolle: siehe ANHANG). Die im Rahmen dieser Markierungsvorgänge entstandenen Zellpellets wurden für das weitere Vorgehen in MACS-Puffer aufgenommen und je nach Zellzahl so aufgeteilt, dass maximal 2,5 Mio. Zellen in $500 \mu$ l MACS-Puffer gelöst wurden.

Die Magnetsäule (MS-Columns, Miltenyi Biotec $\mathrm{GmbH}$, Bergisch Gladbach) der Mini MACS-Separation Unit (Miltenyi Biotec $\mathrm{GmbH}$, Bergisch Gladbach) wurde vorbereitet und mit $500 \mu \mathrm{l}$ MACS-Puffer gespült. Anschließend wurden die in den $500 \mu \mathrm{l}$ MACSPuffer aufgenommenen Zellen in die Säule pipettiert und diese dann dreimal mit jeweils $500 \mu \mathrm{l}$ MACS-Puffer gewaschen. Die markierten (positiven) Zellen blieben in der Säule hängen, während die nicht markierten (negativen) Zellen das Magnetfeld ungehindert passieren und in einem Zentrifugenröhrchen gesammelt werden konnten. Die in den Columns verbliebenen markierten Zellen wurden in ein sauberes Röhrchen eluiert, indem die Säule aus dem Magnetfeld genommen und mit $1 \mathrm{ml}$ MACS-Puffer gespült wurde. Die MAC-Sortierung ist schematisch in Abbildung 7 dargestellt. Die negativen und positiven Zellen wurden gezählt (CASY) und für die Differenzierungsassays verwendet. Die eluierten Mischpopulationen (Stro- $1^{-}$-, CD133- und CD271-Zellen) wurden im Rahmen dieser Untersuchung als Stro-1/CD133/CD271 negativ sortierte Zellen bezeichnet. 


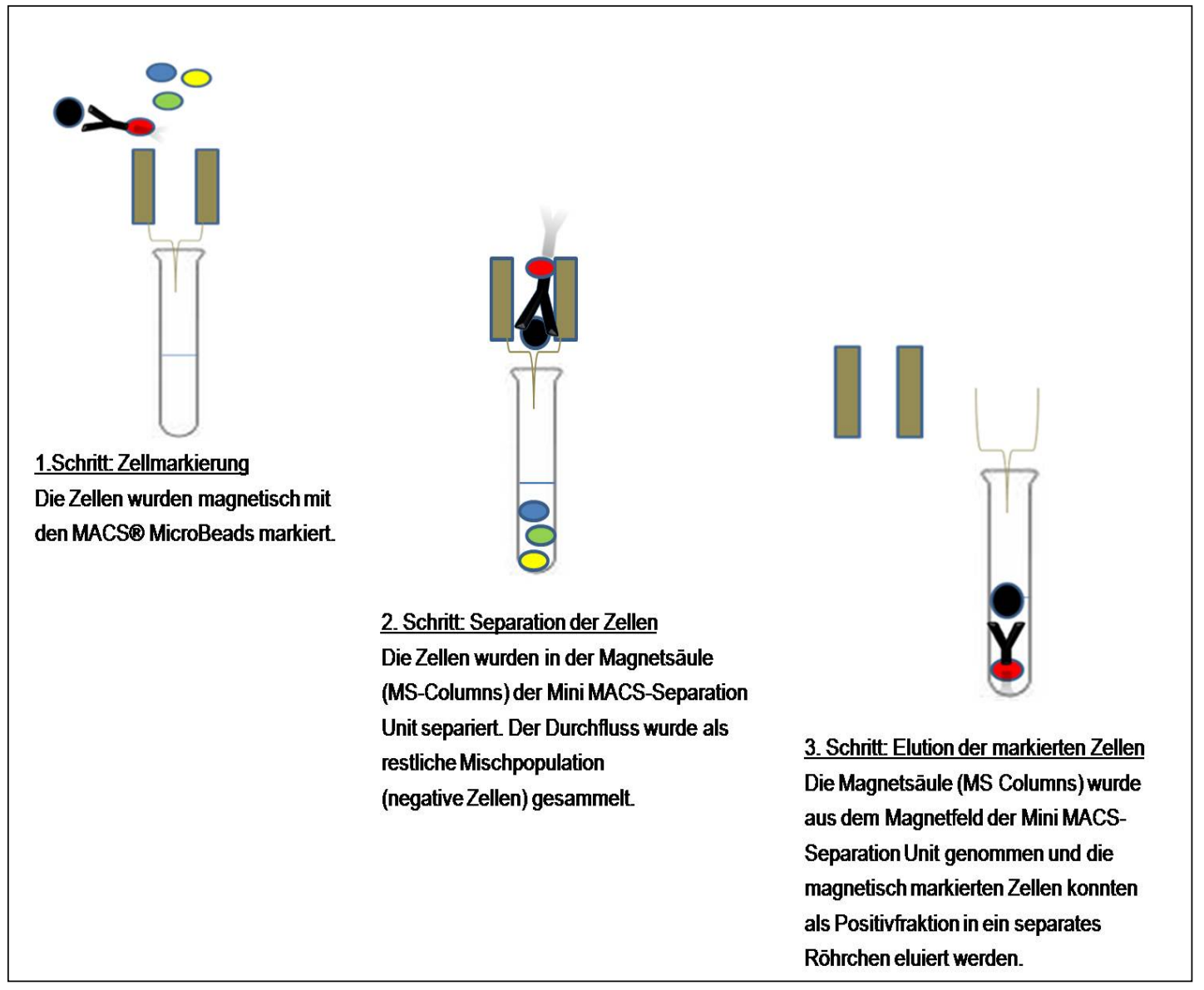

Abb. 7: Schematische Darstellung der MAC-Sortierung (modifiziert nach Miltenyi Biotec®; www.miltenyibiotec.com).

\subsection{Differenzierungsassays}

Im Rahmen des adipogenen Differenzierungsassays wurden die zuvor mittels MACS isolierten Zellpopulationen (CD271+/-Zellen, CD133 ${ }^{+/-}$-Zellen, Stro- $1^{+/-}$-Zellen) in 12-Well-Platten (Greiner, Bio-One $\mathrm{GmbH}$, Solingen) ausplattiert. Für jeden Antikörper (Stro-1, CD133, CD271) wurden zwei 12-Well-Platten mit Zellen versehen. Vier Wells einer Platte wurden mit 50.000 positiv sortierten Zellen des jeweiligen Antikörpers bestückt. In zwei weiteren Wells wurden 50.000 Zellen der restlichen Mischkultur (negativ sortierte Zellen) ausgesät. Die Inkubation der Zellen fand unter den o.g. standardisierten Bedingungen statt. Die Kultivierung der Zellen erfolgte bis zu einer Konfluenz von 70-80\% mit $1 \mathrm{ml} \mathrm{NH-Expansionsmedium} \mathrm{(Miltenyi} \mathrm{Biotec} \mathrm{GmbH}$, Bergisch Gladbach) pro Well. Das Medium wurde alle drei Tage gewechselt. Das Wachstumsverhalten der Zellen wurde täglich mittels Lichtmikroskop kontrolliert. Sobald die Kulturen $70-80 \%$ Konfluenz erreicht hatten, wurde die adipogene Differenzierung induziert (Tag 0). Dafür wurden die Zellen mit PBS gewaschen und mit $1 \mathrm{ml}$ Adipozytendifferenzierungsmedium (Miltenyi Biotec $\mathrm{GmbH}$, Bergisch Gladbach) pro Well unter den oben genannten 
Bedingungen inkubiert. Auch das Differenzierungsmedium wurde während der Versuchsdauer alle zwei bis drei Tage erneuert. An Tag 14 der adipogenen Differenzierung wurden drei der mit positiven Zellen bestückten Wells und ein mit negativen Zellen versehenes Well zur molekularbiologischen Untersuchung geerntet (Well 1+, Well 2+, Well 3+, Well 5-). Die Zellen der verbliebenen Wells (Well 4+, Well 6-) wurden für den Lipidnachweis mittels Öl-Rot-O-Färbung in Formaldehyd fixiert. An Tag 28 wurde identisch mit den Zellen der 2. Platte verfahren. Abbildung 8 zeigt schematisch die Zeitverläufe der adipogenen Differenzierungsassays. Das Ernten der Zellen erfolgte nach dem unten genannten Schema. Sowohl dem Expansions- als auch dem Differenzierungsmedium wurden zum vorbeugenden Schutz vor Kontamination bei jedem Mediumwechsel $10 \mu \mathrm{l}$ Penicillin-Streptomycin-Lösung (Biochrom AG, Berlin) pro Well zugesetzt. Das Stammzellexpansions- und das Adipozytendifferenzierungsmedium wurden aliquotiert bei $-20{ }^{\circ} \mathrm{C}$ im Gefrierschrank (Liebherr, Ochsenhausen) gelagert. Für den Austausch des Mediums wurden die Lösungen im Wasserbad (Memmert, Schwabach) auf $37^{\circ} \mathrm{C}$ temperiert.

Das Ernten der Zellen erfolgte nach Abzug des Mediums, Trypsinierung und Zellzählung. Nach Mobilisation der Zellen wurde das Trypsin $(500 \mu \mathrm{l})$ mit $500 \mu \mathrm{l}$ DMEM inaktiviert und die Zellsuspension in ein Eppendorf-Reaktionsgefäß überführt. Zur Ermittlung der Zellanzahl wurde die Suspension gut vermischt und anschließend $100 \mu \mathrm{l}$ für die Zellzählung abgezogen. Mithilfe des CASY-Zellzählgerätes wurde die Zellanzahl/Well bestimmt. Die verbliebene Zellsuspension wurde $5 \mathrm{~min}$ bei $500 \mathrm{x}$ g und einer Temperatur von $21^{\circ} \mathrm{C}$ pelletiert und in $500 \mu \mathrm{PBS}$ resuspendiert. Das Pellet wurde erneut unter den o.g. Bedingungen zentrifugiert. Der Überstand wurde abgezogen und das verbliebene Zellpellet umgehend in flüssigem Stickstoff tiefgefroren. Die anschließende Lagerung der Zellen erfolgte bis zur molekularbiologischen Aufarbeitung im Gefrierschrank (Sanyo, Bad Nenndorf) bei $-80^{\circ} \mathrm{C}$.

Für jeden der verwendeten Stammzellmarker (CD133, CD271, Stro-1) wurden zwei 12-Well-Platten nach dem oben genannten Schema mit Zellen bestückt (Tabelle 1).

Tab. 1: Schematische Darstellung des adipogenen Versuchsaufbaus.

\begin{tabular}{c|c|c}
\hline CD133 & CD271 & STRO-1 \\
\hline 14-Tage-Platte & 14-Tage-Platte & 14-Tage-Platte \\
28-Tage-Platte & 28-Tage-Platte & 28-Tage-Platte \\
\hline
\end{tabular}



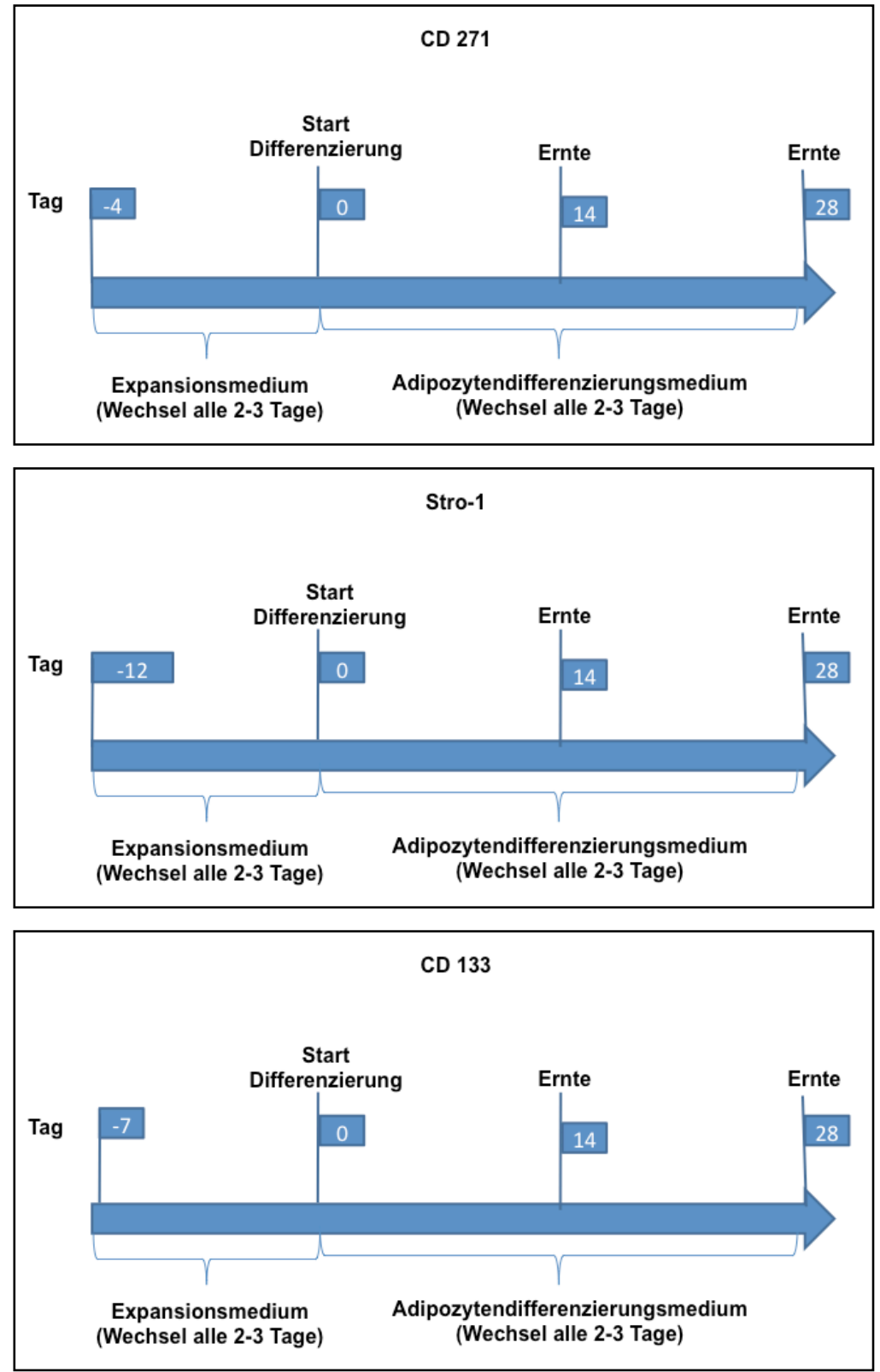

Abb. 8: Schematische Darstellung des Zeitverlaufs der adipogenen Versuchsreihe unter Einbeziehung von Startzeitpunkt der Differenzierung, Erntezeitpunkten und Mediumwechsel.

Die mittels MACS isolierten Zellpopulationen $\left(\mathrm{CD} 271^{+/-}\right.$-Zellen, CD133 ${ }^{+/}$-Zellen, Stro- $1^{+/}$-Zellen) wurden für die chondrogene Differenzierung in 24-Well-Platten (Corning B.V. Life Science, Netherlands) ausplattiert. Für jeden Antikörper wurden zwei Wells einer Platte mit einem Transwell-Einsatz (Corning B.V. Life Science, Netherlands) und 500.000 Zellen versehen. Es wurden jeweils 500.000 positiv und 500.000 negativ sortierte Zellen (restliche Mischkultur) pro Transwelleinsatz („transwell insert“) ausgesät. Dazu wurden die Zellen zuvor in $100 \mu$ l Chondrozytendifferenzierungsmedium (Provitro, Berlin) aufgenommen, auf die permeable Polycarbonatmembran („upper compartment“) des Transwell-Einsatzes pipettiert und bei $200 \times \mathrm{g}$ für $5 \mathrm{~min}$ anzentrifugiert. Anschließend wurden $500 \mu \mathrm{l}$ Chondrozyten- 
differenzierungsmedium durch die Fenster der Einsätze auf den Boden der Wells („lower compartment") suspendiert. In Abbildung 9 ist der Versuchsaufbau des chondrogenen Differenzierungsassays schematisch dargestellt. Der Mediumwechsel fand alle zwei Tage ausschließlich im „lower compartement“ statt. Die Inkubation der Zellen erfolgte im Brutschrank unter den o.g. Bedingungen über einen Zeitraum von 33 Tagen. An Tag 33 wurden die entstandenen Zellpellets zur molekularbiologischen Untersuchung geerntet und in flüssigem Stickstoff tiefgefroren. Das Differenzierungsmedium wurde aliquotiert bei $-20{ }^{\circ} \mathrm{C}$ gelagert und für den Austausch im Wasserbad auf $37^{\circ} \mathrm{C}$ erwärmt.

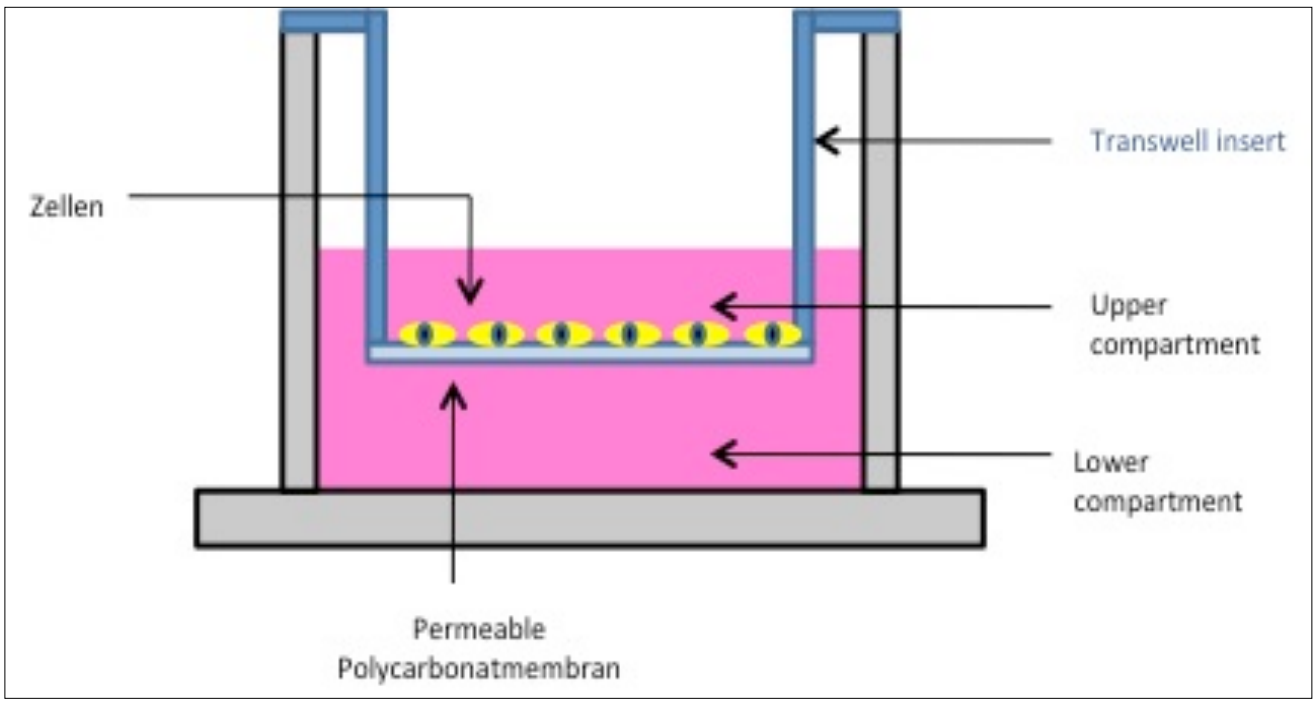

Abb. 9: Schematische Darstellung des Versuchsaufbaus des chondrogenen Assays modifiziert nach SAUNDERS (2009), S.676.

Die osteogene Differenzierung der zuvor mittels MACS isolierten Zellpopulationen $\left(\mathrm{CD} 271^{+/-}\right.$-Zellen, CD133 ${ }^{+/}$-Zellen, Stro- $1^{+/}$-Zellen) erfolgte in 6-Well-Platten (Greiner, Bio-One $\mathrm{GmbH}$, Solingen). Es wurden jeweils drei 6-Well-Platten/Antikörper mit Zellen versehen. In den ersten drei Wells einer Platte wurden jeweils 50.000 positiv sortierte Zellen ausgesät. Das 4. Well wurde mit 50.000 Zellen der restlichen Mischkultur (negativ sortierte Zellen) bestückt, während die letzten zwei Wells unbenutzt blieben. Die Inkubation der Zellen erfolgte unter den o.g. standardisierten Bedingungen. In den ersten fünf Versuchstagen erfolgte die Kultivierung der Zellen mit 1,5 ml NHExpansionsmedium (Miltenyi Biotec $\mathrm{GmbH}$, Bergisch Gladbach) pro Well. Nach zwei Tagen wurde das Expansionsmedium gewechselt. Am 5. Versuchstag wurde die osteogene Differenzierung induziert (Tag 0). Dafür wurden die Zellen mit PBS gewaschen und mit $1,5 \mathrm{ml}$ Osteoblastendifferenzierungsmedium (Miltenyi Biotec $\mathrm{GmbH}$, Bergisch Gladbach) pro Well inkubiert. Die Zellen der 5-Tage-Platten wurden geerntet. An Tag 7 wurde das Differenzierungsmedium der 9-Tage- und der 21-Tage- 
Platte ausgetauscht. Am 9. Versuchstag (4. Tag der Differenzierung) wurden die Zellen der 9-Tage-Platte geerntet und das Medium der 21-Tage-Platte gewechselt. Bis zum Ende des Versuches an Tag 21 wurde das Differenzierungsmedium alle zwei bis drei Tage gewechselt, je nach Höhe des Verbrauchs. Am 21. Versuchstag (16. Tag der Differenzierung) wurden die Zellen der 21-Tage-Platte geerntet. Abbildung 10 zeigt schematisch den Zeitverlauf des osteogenen Differenzierungsassays. Sowohl dem Expansionsmedium als auch dem Differenzierungsmedium wurden zum vorbeugenden Schutz vor Kontamination bei jedem Mediumwechsel jeweils $15 \mu$ PenicillinStreptomycin-Lösung (Biochrom AG, Berlin) pro Well zugesetzt. Beide Medien wurden aliquotiert bei $-20^{\circ} \mathrm{C}$ gelagert und für den Austausch im Wasserbad auf $37^{\circ} \mathrm{C}$ erwärmt. Bei jedem Mediumwechsel wurde aus jedem Well $1 \mathrm{ml}$ Überstand genommen und für den späteren Osteocalcin-ELISA bei $-80^{\circ} \mathrm{C}$ tiefgefroren. Das Ernten der Zellen erfolgte nach o.g. Schema (siehe adipogene Differenzierung).

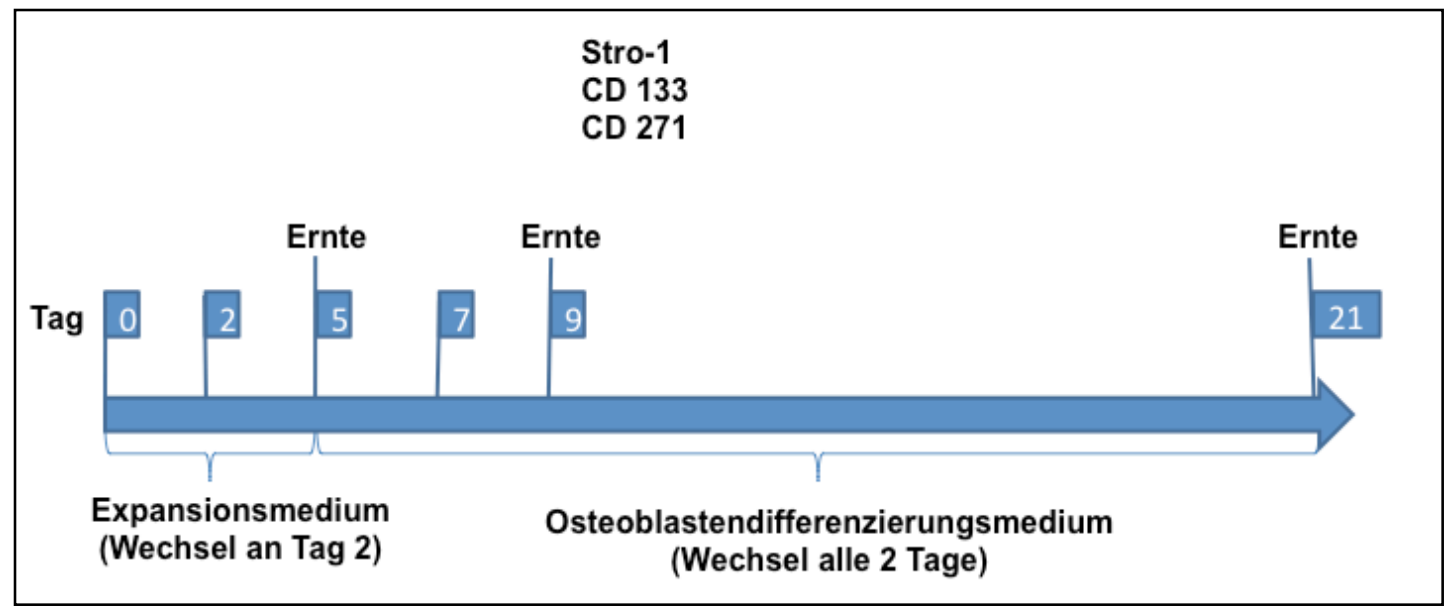

Abb. 10: Schematische Darstellung des Zeitverlaufs der osteogenen Versuchsreihe unter Einbeziehung von Startzeitpunkt der Differenzierung, Erntezeitpunkten und Mediumwechsel.

Für jeden der verwendeten Stammzellmarker (CD133, CD271, Stro-1) wurden drei 6-Well-Platten nach dem oben genannten Schema mit Zellen bestückt (Tabelle 2).

Tab. 2: Schematische Darstellung des osteogenen Versuchsaufbaus.

\begin{tabular}{c|c|c}
\hline CD133 & CD271 & STRO-1 \\
\hline 5-Tage-Platte & 5-Tage-Platte & 5-Tage-Platte \\
9-Tage-Platte & 9-Tage-Platte & 9-Tage-Platte \\
21-Tage-Platte & 21-Tage-Platte & 21-Tage-Platte \\
\hline
\end{tabular}


Das Einfrieren der Zellen erfolgte in flüssigem Stickstoff unmittelbar nach dem Ernten der Zellen. Hierfür wurden die aus den einzelnen Differenzierungsassays gewonnenen Zellen in $2 \mathrm{ml}$ CryoTubes (Nunc, Roskilde, Denmark) überführt und anschließend 5 min mit $500 \times$ g bei $21^{\circ} \mathrm{C}$ zentrifugiert. Der Überstand wurde verworfen und die Zellen in flüssigen Stickstoff getaucht. Die Lagerung bis zur molekularbiologischen Aufbereitung erfolgte bei $-80{ }^{\circ} \mathrm{C}$ im Gefrierschrank (Sanyo, Bad Nenndorf).

Die aus den einzelnen Differenzierungsassays gewonnenen Überstände wurden in Eppendorf-Reaktionsgefäße pipettiert und bei $-80{ }^{\circ} \mathrm{C}$ im Gefrierschrank (Sanyo, Bad Nenndorf) eingefroren.

\subsection{Molekularbiologische Methoden}

Der Nachweis der Transkription von Markergenen wurde mittels Polymerase-KettenReaktion (PCR) bzw. quantitativer Real-time PCR (RTq-PCR) durchgeführt. Diese Verfahren bestehen aus drei Phasen:

$>$ der Isolierung von RNA aus den Zellen,

$>$ der cDNA-Synthese und

$>$ der Amplifikation spezifischer cDNA-Abschnitte mittels PCR/RTq-PCR.

Diese Verfahren stellen reproduzierbare Methoden zur Analyse der Expression von Markergenen auf Transkriptionsebene dar und sind hochspezifisch.

Die Isolierung von RNA aus den Zellkulturproben erfolgte mit dem QIAGEN RNeasy Kit (Qiagen $\mathrm{GmbH}$, Hilden). Die folgenden Arbeitsschritte wurden nach dem Protokoll des Herstellers durchgeführt. Zuerst erfolgte die Lyse der Zellen im Lyse-Puffer (Buffer $\mathrm{RLT}$ ), der vorher mit 1\% ß-Mercaptoethanol versetzt wurde. Anschließend wurde das Lysat auf eine QIAshredder-Säule gegeben und 2 min bei maximaler Drehzahl (16400 rpm) homogenisiert. Der Durchlauf wurde mit 70\%igem Ethanol versetzt, wodurch das selektive Binden der RNA an die RNeasy Membran gefördert wurde. Dieses Gemisch wurde in die RNeasy Zentrifugationsröhrchen überführt und zentrifugiert. Dadurch wurde die RNA an der Membran gebunden. Anschließend erfolgte die Durchführung des DNase-Verdaus mittels RNase-Free Dnase Set (QIAGEN GmbH, Hilden) um Verunreinigungen der RNA durch genomische DNA zu vermeiden. Zuletzt wurde die RNA mit RNase-freiem Wasser eluiert. Die Konzentration und Reinheit der Eluate wurden durch Messung der Exstinktionen bei $260 \mathrm{~nm}$ für Nukleinsäuren und bei $280 \mathrm{~nm}$ für Proteine in einem Photometer bestimmt. Der Quotient aus der optischen Dichte (OD) bei $260 \mathrm{~nm}$ und bei $280 \mathrm{~nm}$ sollte zwischen 1,8 und 2 liegen. Die isolierte 
RNA konnte nun direkt für die cDNA-Synthese eingesetzt oder bei $-70{ }^{\circ} \mathrm{C}$ tiefgefroren werden.

Die Isolierung wurde bei Raumtemperatur in den folgenden 14 Schritten vorgenommen: cDNA-Synthese

1. Die Zellen (max. $5 \times 10^{6}$ ) mit $350 \mu$ l RLT-Puffer/1\% $\beta$-Mercaptoethanol lysieren.

2. Das Lysat auf eine QIAshredder-Säule geben und 2 min mit 16400 rpm zentrifugieren (Eppendorf Zentrifuge 5417C, Wesseling-Berzdorf).

3. Den Durchlauf mit gleichem Volumen $70 \%$ igem Ethanol versetzen und vorsichtig mischen.

4. Das Gemisch sofort auf die RNeasy-Säule geben und (15 sec bei $10.000 \mathrm{rpm}$ ) zentrifugieren. Den Durchlauf verwerfen.

5. Für den DNase-Verdau werden pro Ansatz $10 \mu \mathrm{l}$ DNase I mit $70 \mu \mathrm{l}$ Puffer RDD vorsichtig vermischt und kurz anzentrifugiert.

6. $350 \mu \mathrm{l}$ RW1-Puffer werden auf die Säule gegeben und $15 \mathrm{sec}$ bei $10.000 \mathrm{rpm}$ zentrifugiert. Den Durchlauf verwerfen.

7. $80 \mu \mathrm{l}$ DNase I-Mix aus Schritt 4 werden direkt auf die Membran der Säule pipettiert und für 15 min inkubiert.

8. $350 \mu \mathrm{l}$ RW1-Puffer auf die Säule geben und $15 \mathrm{sec}$ bei $10.000 \mathrm{rpm}$ zentrifugieren. Den Durchlauf verwerfen.

9. $500 \mu \mathrm{l}$ RPE-Puffer auf die Säule geben und $15 \mathrm{sec}$ bei $10.000 \mathrm{rpm}$ zentrifugieren. Den Durchlauf verwerfen.

10. Schritt 8 wiederholen.

11. Die Säule wird 2 min bei 10.000 rpm zentrifugiert, um Reste des Puffers zu entfernen.

12. Die Säule wird in ein neues Eppendorf-Reaktionsgefäß gestellt und es werden 30 (-50) $\mu$ l RNase-freies Wasser direkt auf die Membran gegeben. Anschließend wird die Säule $1 \mathrm{~min}$ bei 10.000 rpm zentrifugiert.

13. Das Eluat wird direkt auf Eis gestellt und $1 \mu \mathrm{l}$ in einer 1:100-Verdünnung im Photometer gemessen.

14. RNA bei $-70{ }^{\circ} \mathrm{C}$ lagern oder direkt für die cDNA-Synthese einsetzen. 
Die cDNA Synthese erfolgte im Anschluss an die RNA-Isolierung mithilfe des iScript cDNA Synthesis Kit (BioRad Laboratories $\mathrm{GmbH}$, München) nach Herstellerangaben. Zur weiteren Untersuchung der mRNA-Genexpression muss die zuvor isolierte mRNA in cDNA umgeschrieben werden. Oligonukleotide (Oligo(dT)) binden an die poly(A)Enden der mRNA und mithilfe des viralen Enzyms Reverse Transkriptase (RT) wird die messenger-RNA in cDNA umgeschrieben und es kommt zur Synthese komplementärer DNA-Stränge. Im Rahmen der cDNA-Synthese wurden (wenn nicht anders vermerkt) 200 ng extrahierte RNA eingesetzt.

\section{Reaktionsansatz $(20 \mu \mathrm{l})$ :}

$4 \mu \mathrm{l} \quad$ iScript-Mastermix

$1 \mu \mathrm{l} \quad$ Reverse Transkriptase

$15 \mu \mathrm{l} 200 \mathrm{ng}$ RNA-Template (+Nuklease-freies Wasser).

Der Reaktionsansatz wurde gut durchmischt und durchlief anschließend im MasterCycler Gradient (Eppendorf, Wesseling Berzdorf) verschiedene Inkubationsphasen. Zuerst erfolgte eine 5 -minütige Inkubation bei $25^{\circ} \mathrm{C}$, wodurch alle Komponenten auf Zimmertemperatur erwärmt wurden. Im nächsten Schritt wurde die RNA-Probe für 30 min bei $42{ }^{\circ} \mathrm{C}$ inkubiert. In dieser Phase wurde die mRNA mithilfe der Reversen Transkriptase, den Oligo (dT) und „random primern“ in cDNA umgeschrieben. Das Stoppen der Reaktion erfolgte durch eine 5-minütige Denaturierung des Enzyms bei einer Temperatur von $85^{\circ} \mathrm{C}$. Die entstandene cDNA wurde für den direkten weiteren Gebrauch auf $4{ }^{\circ} \mathrm{C}$ abgekühlt oder zur Lagerung bei $-20{ }^{\circ} \mathrm{C}$ tiefgefroren.

Die Polymerase-Kettenreaktion ist ein Verfahren, mit dem ein bestimmter DNAAbschnitt millionenfach amplifiziert werden kann. Nach Auftrennung doppelsträngiger DNA wird mithilfe der Taq-DNA-Polymerase der gewünschte DNA-Abschnitt vervielfältigt. Es hybridisieren zwei Oligonukleotide, auch als Primer bezeichnet, spezifisch an ihre komplementären Sequenzen des gesuchten Genabschnitts und bilden somit den Startpunkt für die Taq-DNA-Polymerase. Durch die Zugabe von Nukleotiden (dATP, dGTP, dCTP, dTTP) kann nun die Synthese des komplementären DNA-Stranges erfolgen. Der Ablauf der PCR kann in drei Phasen unterteilt werden, welche sich in Länge und Temperatur unterscheiden: 
Denaturierung: Die DNA-Doppelstränge werden auf ca. $94-96{ }^{\circ} \mathrm{C}$ erhitzt und dadurch denaturiert. Dies führt zur Trennung der DNA-Doppelstränge.

$>$ Annealing: Bei einer Temperatur von ca. 50-60 ${ }^{\circ} \mathrm{C}$ findet die Hybridisierung der Primer an die komplementären DNA-Sequenzen statt.

$>$ Elongation: Bei einer Temperatur von $72{ }^{\circ} \mathrm{C}$ findet die Synthese des komplementären DNA-Stranges durch die Aktivität der Taq-DNA-Polymerase statt. Der entsprechende Einzelstrang wird in 5'-3'-Richtung synthetisiert.

Dieser Vorgang stellt einen Zyklus dar. In jedem durchlaufenen Zyklus wird die Menge der gebildeten Moleküle verdoppelt und es kommt im Idealfall zu einer exponentiellen Vermehrung der spezifischen Sequenz. Üblicherweise werden ca. 30-40 Zyklen durchlaufen, je nach Intensität des zu erwartenden Expressionssignals. Die jeweiligen PCRBedingungen werden durch das Programmieren des Thermocyclers festgelegt.

Der Temperaturverlauf der durchgeführten PCR-Reaktionszyklen hatte das nachfolgende Protokoll. Die Annealing-Temperatur $\left(\mathrm{X}^{\circ} \mathrm{C}\right)$ des jeweiligen Ziel-Gens ist in der Tabelle 3 aufgeführt.

$\begin{array}{rrrl}1 \times & 2 \mathrm{~min} & 95^{\circ} \mathrm{C} & \text { (initiale Denaturierung) } \\ 40 \times & 45 \mathrm{sec} & 95{ }^{\circ} \mathrm{C} & \text { (Denaturierung) } \\ 40 \times & 45 \mathrm{sec} & \times{ }^{\circ} \mathrm{C} & \text { (Annealing) } \\ 40 \times & 45 \mathrm{sec} & 72{ }^{\circ} \mathrm{C} & \text { (Elongation) } \\ 1 \times & 5 \mathrm{~min} & 72{ }^{\circ} \mathrm{C} & \text { (finale Elongation) } \\ \infty & & 4{ }^{\circ} \mathrm{C} & \end{array}$

Reaktionsansatz $(20 \mu \mathrm{l})$ :

$1 \mu \mathrm{l} \quad \mathrm{cDNA}$

$1 \mu \mathrm{l} \quad$ Primermix ("forward" und "reverse") je $10 \mathrm{pmol} / \mu \mathrm{l}$

$10 \mu \mathrm{l}$ Go Taq Green Master Mix (Promega)

$8 \mu \mathrm{l}$ bidest. Wasser 
Tab. 3: Auflistung der Ziel-Gene, Primer-Sequenzen, Annealing-Temperaturen ( $T$ ) und die Fragmentgröße der cDNA in Basenpaaren (bp).

\begin{tabular}{|c|c|c|c|}
\hline Ziel-Gen & $\begin{array}{l}\text { Primersequenzen } \\
\text { (forward/reverse) }\end{array}$ & $\begin{array}{c}\mathrm{T} \\
\left({ }^{\circ} \mathrm{C}\right)\end{array}$ & $\begin{array}{l}\text { cDNA } \\
\text { (bp) }\end{array}$ \\
\hline GAPDH & $\begin{array}{l}\text { 5'-CGAGATCCCTCCAAAATCAA-3' } \\
\text { 5'-GGAGGCATTGCTGATGATCT-3' }\end{array}$ & 50 & 216 \\
\hline Osteocalcin & $\begin{array}{l}\text { 5'-AAGCAGGAGGGCAGCGAGGT-3' } \\
\text { 5'-CGTAGAAGCGCCGATAGGC-3' }\end{array}$ & 52 & 178 \\
\hline Osteonectin & $\begin{array}{l}\text { 5'-GATGAGACAGAGGTGGTGGAAG-3' } \\
\text { 5'-GGGGTCCTGGCACACGCACAT-3' }\end{array}$ & 55 & 218 \\
\hline Osteopontin & $\begin{array}{l}\text { 5'-GAGTCTCACCATTCTGATGA-3' } \\
\text { 5'-CACACTATCACCTCGGCCAT-3' }\end{array}$ & 52 & 126 (human) \\
\hline Osteocrin & $\begin{array}{l}\text { 5'-GACTGGAGATTGGCAAGTGC-3' } \\
\text { 5'-GCCTCTGGAATTTGAAAGCC-3' }\end{array}$ & 55 & 393 \\
\hline Cbfa1 & $\begin{array}{l}\text { 5'-CATAACCGTCTTCACAAATCCTCCC-3' } \\
\text { 5'-GTGAGGGATGAAATGCTTGGGAAC-3' }\end{array}$ & 55 & 443 \\
\hline Kollagen1a1 & $\begin{array}{l}\text { 5'-GACCTCCGGCTCCTGCTCCTCTTAG-3' } \\
\text { 5'-GGACCCATGGGGCCAGGCACGGAAA-3' }\end{array}$ & 53 & 532 \\
\hline Chondroadherin & $\begin{array}{l}\text { 5'-TGGTGGAGGAGCTGAAGCTGT-3' } \\
\text { 5'-CTTCTCCAGGTTGGTGTTGTCC-3' }\end{array}$ & 58 & 116 \\
\hline Aggrecan & $\begin{array}{l}\text { 5'-GATCATCACCACACAGTCCT-3' } \\
\text { 5'-GAACGACAAGACCATCGAAG-3' }\end{array}$ & 60 & 124 \\
\hline Sox9 & $\begin{array}{l}\text { 5'-CTGAAGAAGGAGAGCGAGGA-3' } \\
\text { 5'-CTTGTTCTTGCTCGAGCCGT-3' }\end{array}$ & 60 & 129 \\
\hline FABP4 & $\begin{array}{l}\text { 5'-ATGCTTTTGTAGGTACCTGG-3' } \\
\text { 5'-СTCTCTCATAAACTCTGTG-3' }\end{array}$ & 57 & 387 \\
\hline PPAR $\gamma$ & $\begin{array}{l}\text { 5'-GTTGACTTCTCCAGCATTTC-3' } \\
\text { 5'-CAAGCATGAACTCCATAGTG-3' }\end{array}$ & 52 & 266 \\
\hline
\end{tabular}

Sogenannte "housekeeping"-Gene sind Gene, die konstitutiv und unabhängig von intra- oder extrazellulären Vorgängen exprimiert werden. Dementsprechend wird angenommen, dass die Genexpression eines „housekeeping“-Gens immer konstant bleibt und somit als internes Referenzgen verwendet werden kann. Daher kann mit Hilfe eines „housekeeping“-Gens sowohl die Intaktheit der eingesetzten cDNA als auch die Primerspezifität überprüft werden. Im Rahmen der hier durchgeführten PCR wurde Glycerinaldehyd-3-phosphat-Dehydrogenase (GAPDH) als „housekeeping“-Gen 
verwendet. GAPDH ist ein Enzym der Glykolyse und wird von jeder Zelle eines Lebewesens exprimiert.

Die quantitative Real-time PCR (RTq-PCR) ist ein Verfahren, mit dem die Expressionshöhe bestimmter Marker zwischen verschiedenen Differenzierungszeitpunkten bestimmt und quantitativ verglichen werden kann. Im Gegensatz zu der konventionellen PCR findet eine Echtzeit-Überwachung der einzelnen Amplifikationszyklen nach jedem Elongationsschritt statt. Im Rahmen dieses Versuches wurde der iQ SYBR Green Supermix der Firma Bio-Rad verwendet. Die Durchführung erfolgte nach dem Herstellerprotokoll. SYBR Green ist ein Fluoreszenzfarbstoff, welcher in die doppelsträngige DNA interkaliert und bei Anregung ein Fluoreszenzsignal abgibt. Die Fluoreszenzintensität ist hierbei proportional zu der Menge der amplifizierten PCRProdukte. Im Anschluss an die Amplifikation wurde eine Schmelzkurvenanalyse durchgeführt. Hierbei wurde die Temperatur alle $10 \mathrm{sec}$ jeweils um $0,5{ }^{\circ} \mathrm{C}$ von $55{ }^{\circ} \mathrm{C}$ auf $95{ }^{\circ} \mathrm{C}$ erhöht. Die PCR-Produkte denaturieren bei einer produktspezifischen Temperatur. Diese Denaturierungstemperatur der DNA-Moleküle ist abhängig von deren Lage und Basensequenz. Da SYBR Green nur an doppelsträngige PCR-Produkte bindet, nimmt die Fluoreszenz bei Erreichen der jeweiligen Denaturierungstemperatur der einzelnen Produkte ab. Folglich entsteht auf der Temperaturkurve für jedes Produkt ein spezifischer Peak. Die Durchführung erfolgte nach dem Herstellerprotokoll. Es wurden folgende Protokolle verwendet:

Standard-Protokoll:

$\begin{array}{lrll}1 \mathrm{x} & 3 \mathrm{~min} & 95^{\circ} \mathrm{C} & \text { (initiale Denaturierung) } \\ 40 \times & 10 \mathrm{sec} & 95{ }^{\circ} \mathrm{C} & \text { (Denaturierung) } \\ 40 \times & 30 \mathrm{sec} & 60^{\circ} \mathrm{C} & \text { (Annealing/Elongation) } \\ 1 \times & 1 \mathrm{~min} & 95{ }^{\circ} \mathrm{C} & \text { (Elongation) } \\ 1 \times & 1 \mathrm{~min} & 55^{\circ} \mathrm{C} & \text { (finale Elongation) }\end{array}$

Reaktionsansatz $(25 \mu \mathrm{l})$ :

$\begin{array}{ll}5 \mu \mathrm{l} & \text { Template (cDNA) (1:5 vorverdünnt) } \\ \text { je } 0,4 \mu \mathrm{l} & \text { Primer-Mix }(10 \mathrm{pmol} / \mu \mathrm{l}) \\ 12,5 \mu \mathrm{l} & \text { SYBR Green Supermix } \\ 7,1 \mu \mathrm{l} & \text { bidest. Wasser }\end{array}$

Schmelzkurvenanalyse:

$55^{\circ} \mathrm{C}-95^{\circ} \mathrm{C} \quad 10 \mathrm{sec} \quad 81 \times$ jeweils $0,5^{\circ} \mathrm{C}$ erhöhen 


\subsection{Osteocalcin-ELISA}

Osteocalcin ist ein nicht-kollagenes Protein der Knochenmatrix und wird von Osteoblasten synthetisiert. Die Osteocalcinkonzentration wurde im Überstand mittels eines „enzyme linked immunosorbent assay“ (ELISA) der Firma Nordic Bioscience Diagnostics (Herlev, Dänemark) bestimmt. Die aus den osteogenen Assays gewonnenen Überstände wurden bis zur Durchführung der ELISAs bei $-80^{\circ} \mathrm{C}$ gelagert und für die ELISAs auf Raumtemperatur erwärmt und durchmischt. Bei den verwendeten ELISAs handelt es sich um einen Sandwich-enzymimmunologischen Test, mit dem eine quantitative Bestimmung von Osteocalcin durchgeführt werden kann. Das Testprinzip basiert auf der Verwendung von zwei spezifischen Antikörpern gegen humanes Osteocalcin. Ein Antikörper, der die mittlere Region des Osteocalcins (Aminosäure 20-43) erkennt, wird als Fänger-Antikörper benutzt. Ein weiterer Peroxidase-konjugierter Antikörper ist spezifisch für die N-terminale-Region (Aminosäure 10-16) und dient dem Nachweis von Osteocalcin.

Zuerst wurden $20 \mu \mathrm{l}$ der Standards, Kontrollen und entsprechender Überstände in die mit Streptavidin beschichteten Mikrotiterwells der 96-Well-Platte pipettiert. Anschließend erfolgte die Zugabe von $150 \mu$ l Antikörperlösung, bestehend aus biotinylierten bzw. mit Peroxidase konjugierten Antikörpern. Mithilfe eines adhäsiven Klebestreifens wurden die Wells verschlossen und die Lösungen 120 min bei Raumtemperatur $\left(21^{\circ} \mathrm{C}\right)$ inkubiert. Bei Vorhandensein von Osteocalcin in den Proben der Überstände bildet sich ein Komplex aus Osteocalcin-Antigen, biotinyliertem Antikörper und Peroxidase-konjugiertem Antikörper. Durch die hohe Affinität des biotinylierten Antikörpers zum Streptavidin bindet der Komplex an die Oberfläche der Wells. Im Anschluss an die Inkubation wurden die Wells fünfmal manuell mit Waschlösung gewaschen, bevor die Zugabe von $100 \mu \mathrm{l}$ chromogener Substratlösung (TMB Tetramethylbenzidine) pro Well erfolgte. Die Platten wurden erneut mit Klebeband verschlossen und im Dunkeln bei Raumtemperatur $\left(21^{\circ} \mathrm{C}\right)$ im Thermoshaker für 15 min inkubiert. Die nun stattfindende Farbreaktion wurde durch die Zugabe von $100 \mu$ l Stoppreagenz (Schwefelsäure $\mathrm{H}_{2} \mathrm{SO}_{4}$ ) pro Well beendet. Anschließend konnte die Absorption bei $450 \mathrm{~nm}$ mit $620 \mathrm{~nm}$ als Referenz innerhalb von zwei Stunden im ELISA-Reader gemessen werden. Die Absorption ist proportional zu der Osteocalcinkonzentration in der Probe. Abbildung 11 stellt den oben beschriebenen ELISA schematisch dar. 


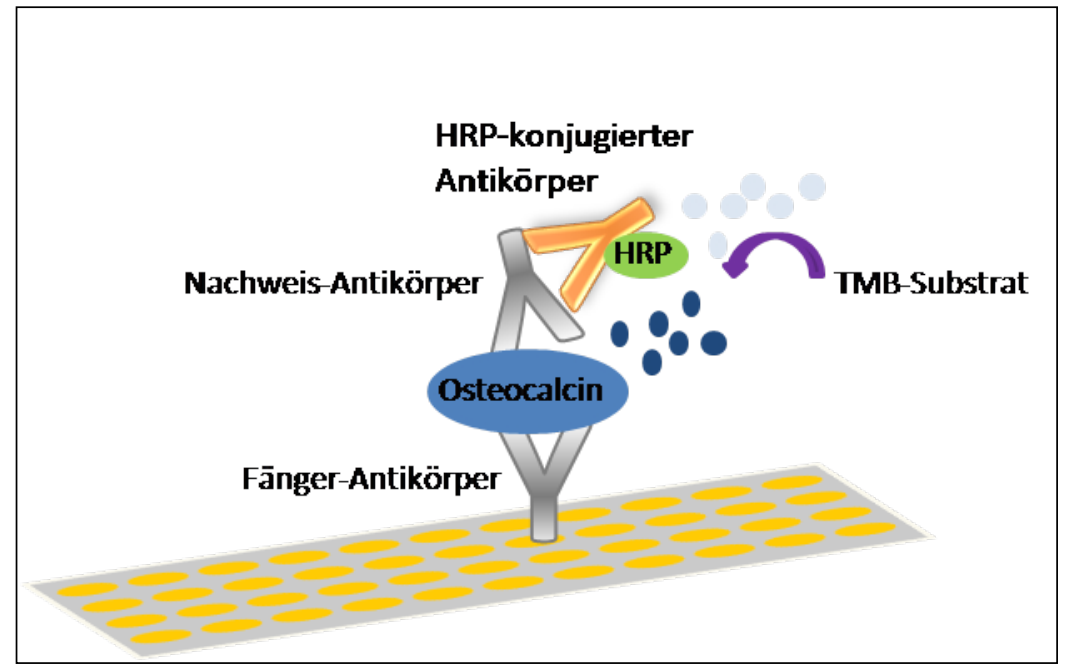

Abb. 11: Schematische Darstellung eines „enzyme linked immunosorbent assays“ (ELISA). Die Darstellung ist abgewandelt von Cell Signaling Technology ${ }^{\circledR}$; (www.cellsignal.com). (HRP = „horseradishperoxidase" (Meerrettichperoxidase), TMB = Tetramethylbenzidin).

\section{7 Öl-Rot-O-Färbung}

Die Öl-Rot-O-Färbung ist spezifisch für Lipidvakuolen und wurde daher für den Nachweis von Adipozyten verwendet. Die gefärbten Lipidvakuolen erscheinen im Lichtmikroskop rot. Die Färbung wurde an allen in Paraformaldehyd fixierten Zellen der adipogenen Assays durchgeführt. Die 12-Well-Platten wurden bis zur Färbung mit Parafilm verschlossen und im Kühlschrank gelagert. Es wurden 0,5 g Öl-Rot-O in $100 \mathrm{ml}$ 99\%igem Isopropanol gelöst, die Stammlösung im Verhältnis 3/2 mit destilliertem Wasser versetzt und filtriert. Diese Öl-Rot-O-Gebrauchslösung wurde kurz vor Gebrauch hergestellt. Das Paraformaldehyd wurde abpipettiert und die Zellen im Anschluss zweimal mit $1 \mathrm{ml}$ PBS gewaschen. Daraufhin wurden $500 \mu \mathrm{l}$ Öl-Rot-OGebrauchslösung in jedes Well pipettiert. Nach 60-minütiger Inkubation bei Zimmertemperatur $\left(21^{\circ} \mathrm{C}\right)$ wurde die Gebrauchslösung abpipettiert und die Zellen vorsichtig einmal mit PBS gewaschen. Anschließend wurden die Zellen mit $500 \mu \mathrm{l}$ PBS bedeckt, mikroskopiert und fotografiert (Mikroskop Carl Zeiss Vision $\mathrm{GmbH}$, Hallbergmoos).

\subsection{Messungen und Berechnungen}

Zur Charakterisierung des Proliferationsverhaltens der verschiedenen Zellreihen wurden aus den Messungen der Zellzahlen Mittelwerte gebildet, die gegen die Zeit in der Kultur aufgetragen wurden. Die entsprechenden Progressionskurven wurden dann mit Hilfe der JMAK-Formel errechnet. 


\section{Ergebnisse}

\subsection{Proliferationsverhalten der Zahnkeimzellen}

Die Kultivierung und Proliferation der Zahnkeimzellen erfolgte unter den in „Material und Methoden" beschriebenen standardisierten Bedingungen. Bei Erreichen der Konfluenz wurden die Zellkulturen passagiert und weiter kultiviert. Die verwendeten Zahnkeimpopulationen befanden sich zum Zeitpunkt der MAC-Sortierung Z.T. in unterschiedlichen Passagen. Die Sortierung erfolgte anhand der Stammzellmarker Stro-1, CD271 und CD133 und konnte problemlos durchgeführt werden.

Tabelle 4 zeigt die absoluten und relativen Zellzahlen nach der MAC-Sortierung mit den o.g. Stammzellmarkern. Es werden positive und negative Zellen unterschieden. Die mit den Stammzellmarkern gekoppelten Zellen werden als positiv definiert. Die restliche Population, welche nicht an den entsprechenden Marker gebunden hat, wird als negativ bezeichnet. Neben den Zellzahlen sind die jeweiligen Passagen der verwendeten Zahnkeimpopulation zum Zeitpunkt der MAC-Sortierung aufgeführt.

Tab. 4: Relative und absolute Zellzahlen der Zahnkeimpopulationen nach der MAC-Sortierung mit den Stammzellmarkern Stro-1, CD133 und CD271. Des Weiteren ist der Tabelle zu entnehmen, in welcher Passage sich die verwendeten Zahnkeimpopulationen zum Zeitpunkt der Sortierung befanden.

\begin{tabular}{|c|c|c|c|c|c|c|c|}
\hline \multirow{2}{*}{ Passage } & \multirow{2}{*}{ total } & \multicolumn{3}{|c|}{ Zellquantität (absolut) } & \multicolumn{3}{|c|}{ Zellquantität (relativ) } \\
\hline & & Sortierung & positiv & negativ & total & positiv & negativ \\
\hline 2 & 7.908 .800 & \multirow{2}{*}{ Stro1 } & 461.900 & 7.447 .900 & $100,00 \%$ & $5,84 \%$ & $94,16 \%$ \\
\hline 3 & 12.742 .027 & & 555.527 & 12.186 .500 & $100,00 \%$ & $4,36 \%$ & $95,64 \%$ \\
\hline 1 & 9.583 .600 & \multirow{2}{*}{ CD133 } & 856.000 & 8.727 .600 & $100,00 \%$ & $8,93 \%$ & $91,07 \%$ \\
\hline 5 & 8.002 .950 & & 645.900 & 7.357.050 & $100,00 \%$ & $8,07 \%$ & $91,93 \%$ \\
\hline 2 & 3.342 .533 & \multirow{2}{*}{ CD271 } & 357.000 & 2.985 .533 & $100,00 \%$ & $10,68 \%$ & $89,32 \%$ \\
\hline 4 & 22.429 .805 & & 666.560 & 21.763 .245 & $100,00 \%$ & $2,97 \%$ & $97,03 \%$ \\
\hline
\end{tabular}

Der Anteil positiver bzw. markierter Zellen an der Gesamtpopulation der Zahnkeimzellen ist bei allen drei Stammzellmarkern deutlich geringer als der Anteil negativer Zellen. Bei den Stro-1-Zellen ist kein deutlicher Unterschied bzgl. der relativen Anzahl positiver Zellen zwischen den einzelnen Passagen zu erkennen. Der Ertrag an CD133+-Zellen unterscheidet sich nicht nennenswert zwischen den Passagen. Der Ertrag ist prozentual aber höher als der Ertrag der Stro- $1^{+}$-Zellen. Die Positivfraktionen der 
CD271-Zellen unterscheiden sich bzgl. der relativen Zellzahlen bei den einzelnen Passagen. Die relative Zellzahl der markierten positiven Zellen scheint mit zunehmender Passage deutlich kleiner zu werden. Am deutlichsten fällt dies bei den CD271 ${ }^{+}$-Zellen auf. Die 2. Passage enthält prozentual einen höheren Anteil an CD271 ${ }^{+}$-Zellen als die Zellpopulation der 4. Passage. Insgesamt liegt die relative Zellquantität aller markierten Zellen zwischen 2-11\%. Keiner der verwendeten Stammzellmarker zeigt einen deutlich höheren Anteil (\%) an positiv markierten Zellen.

\subsubsection{Proliferationsverhalten im osteogenen Differenzierungs- medium}

Die osteogenen Differenzierungsassays wurden über einen Zeitraum von 21 Tagen durchgeführt. Die sortierten Zellpopulationen $\left(\mathrm{CD} 133^{+/-}\right.$, $\mathrm{CD} 271^{+/-}$-, Stro- $1^{+/-}$-Zellen) wurden jeweils fünf Tage im Expansionsmedium und für die restliche Versuchsdauer in osteogenem Differenzierungsmedium kultiviert. An acht Tagen des Versuchsablaufes wurde im Rahmen des Mediumwechsels $1 \mathrm{ml}$ Überstand/Well genommen und im Anschluss mittels ELISA auf dessen Osteocalcinkonzentration untersucht, wodurch sich acht Messdaten ergaben. Die Zellzahl betrug zu Beginn der Versuchsdurchführung 50.000 Zellen/Well. An Tag 5, 9 und 21 erfolgte nach dem Ernten der Zellen eine erneute Bestimmung der Zellzahl mittels CASY, woraus sich vier Messdaten ergaben.

Im Folgenden wurde die zeitliche Entwicklung der Zellzahlen mit einem Modell analysiert, das sowohl die Geschwindigkeit als auch die Dimensionalität eines Wachstumsprozesses berücksichtigt. Die angewendete Fitfunktion basiert auf dem JMAK-Modell für Kristallwachstum, welches aber schon in der Vergangenheit erfolgreich auf Proteinund Zellwachstum angewendet werden konnte. Die Fitfunktion in Bezug auf die hier vorliegenden Untersuchungen lautet:

$y=m\left(1-\exp \left(-k t^{n}\right)\right)+50.000$

wobei $\mathrm{m}$ die Gesamtanzahl im Maximum darstellt. $\mathrm{K}$ beschreibt die Geschwindigkeitskonstante des Wachstums und der sogenannte Avrami-Exponent $\mathrm{n}$ die Dimensionalität des Wachstums mit dim = n-1. Der Summand 50.000 stellt die Anfangsanzahl der Zellen dar. Die beobachteten Dimensionalitäten reichen von 1,9-6,7 (Mittelwert von 3,59 \pm $1,67)$, was durch die Zellbildung zu erwarten war. Die Wachstumsgeschwindigkeitskonstante $\mathrm{k}$ variiert je nach selektierter Zellart recht stark. Die einzelnen Werte für $\mathrm{k}$ und $\mathrm{n}$ der jeweiligen Zellpopulation sind in Tabelle 5 angegeben. Der mittlere Bestimmtheitskoeffizient der Fitfunktionen aller Messung liegt bei $R^{2}{ }_{\text {Mittel }}=0,9418$. 
Tabelle 5 und Abbildung 12 zeigen das Proliferationsverhalten der Stro- ${ }^{+/-}-, \mathrm{CD}_{133^{+/}}$und CD271 $1^{+/}$-Zellen.

Tab. 5: Die Tabelle gibt die maximale Zellzahl, die Wachstumsgeschwindigkeitskonstante $(k)$ der Stro- $1^{+/}$-, $\mathrm{CD} 133^{+/}$- und $\mathrm{CD} 271^{+/}$-Zellen im osteogenen Differenzierungsmedium wieder. Des Weiteren sind die Dimensionalität des Wachstums ( $\operatorname{dim}=\mathrm{n}-1)$ und der Bestimmtheitskoeffizient der Regression $\left(R^{2}\right)$ dargestellt.

\begin{tabular}{c|cccc}
\hline Zelltyp & Max. Zellzahl & K(Tage/Zelle) & dim=n-1 & $\boldsymbol{R}^{\mathbf{2}}$ \\
\hline CD133 $^{+}$ & 761.359 & $1,6 \times 10^{-6}$ & 5,42 & 0,99492 \\
CD133 $^{-}$ & 815.417 & $3,6 \times 10^{-7}$ & 6,73 & 0,80670 \\
CD271 $^{+}$ & 1.347 .641 & $9,9 \times 10^{-6}$ & 5,31 & 0,93053 \\
CD271 $^{-}$ & 1.434 .625 & $2,3 \times 10^{-3}$ & 1,94 & 0,99802 \\
Stro-1 $^{+}$ & 430.131 & $9,0 \times 10^{-5}$ & 3,50 & 0,97282 \\
Stro-1 $^{-}$ & 848.343 & $7,0 \times 10^{-5}$ & 4,64 & 0,94783 \\
\hline
\end{tabular}

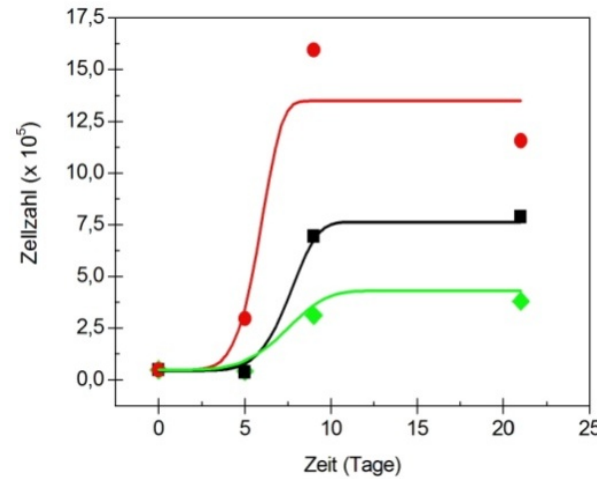

a)

Abb. 12: Abbildung a) zeigt das Proliferationsverhalten der Stro- $1^{+}-$(grün), CD $133^{+}-($schwarz) und CD271 ${ }^{+}$- (rot) sortierten Zellen, Abbildung b) stellt das Proliferationsverhalten der Stro-1- (grün), CD133(schwarz) und CD271- - (rot) sortierten Zellen des osteogenen Assays im direkten Vergleich dar. Angegeben sind für die positiv sortierten Zellen die Mittelwerte (Anzahl der Stichproben = 3).

Aus den Graphen der Abbildung 12 und den Daten der Tabelle 5 geht hervor, dass die CD133'-Zellen in ihrem Proliferationsverhalten keine deutlichen Unterschiede zu den CD133-Zellen aufweisen. Nach inaktiver Phase ( fünf Tage) zeigen beide Populationen sehr schnelle Wachstumsgeschwindigkeitskonstanten mit 1,6 × 10-6 Tagen/Zelle (CD133 positiv) bzw. 3,6 x $10^{-7}$ Tagen/Zelle (CD133 negativ), wobei die CD133-Zellen nur geringfügig schneller proliferieren. In Bezug auf die Dimensionalität dim = n-1 sind zwischen den beiden Zellpopulationen keine deutlichen Unterschiede evident. Die maximale Zellzahl der CD133+-Zellen beträgt 761.359 und unterscheidet sich hiermit nicht deutlich von den CD133-Zellen mit einer Zellzahl von 815.417. Die Stro-1 ${ }^{+}$-Zellen weisen eine Wachstumsgeschwindigkeitskonstante von 9,0 × 10-5 Tagen/Zelle auf und die Stro-1'-Zellen proliferieren mit einer Wachstumsgeschwindigkeitskonstanten von 
$7,0 \times 10^{-5}$ Tagen/Zelle. Beide Zellpopulationen zeigen demzufolge eine ähnliche Wachstumsgeschwindigkeitskonstante. Die Dimensionalitäten liegen bei 3,50 (Stro- ${ }^{+}$) bzw. 4,64 (Stro-1 $\left.{ }^{-}\right)$und unterscheiden sich nicht deutlich. Bzgl. des Proliferationsverhaltens der beiden Zellpopulationen ist ein Unterschied evident. Die Stro1'-Zellen erreichen eine maximale Zellzahl von 848.343, während die Stro- $1^{+}$-Zellen mit einer maximalen Zellzahl von 430.131 deutlich weniger proliferieren.

Bei dem CD271-Ansatz ist ein Unterschied bzgl. der Wachstumsgeschwindigkeitskonstanten zwischen den positiven und negativen Zellen zu beobachten. Die CD271Zellen proliferieren mit einer Wachstumsgeschwindigkeitskonstanten von 2,3 $\times 10^{-3}$ Tagen/Zelle wesentlich langsamer als die CD271+-Zellen mit einer Wachstumsgeschwindigkeitskonstanten von $9,9 \times 10^{-6}$ Tagen/Zelle. Ebenfalls unterscheiden sich die Dimensionalitäten dim $=\mathrm{n}-1$ der beiden Ansätze. Bei den $\mathrm{CD} 271^{+}$-Zellen beträgt die Dimensionalität 5,31 bei den CD271'-Zellen lediglich 1,94. I Bezug auf die Zellzahl zeigen sich keine deutlichen Unterschiede zwischen den beiden Zellpopulationen. Die CD271 ${ }^{+}$-Zellen erreichen eine maximale Zellzahl von 1.347.641 Zellen und die CD271'-Zellen eine Zellzahl von 1.434.625.

Im direkten Vergleich der positiv sortierten Zellen wird deutlich, dass die CD271 ${ }^{+}$-Zellen am stärksten und die Stro- $1^{+}$-Zellen am langsamsten proliferieren. Die CD271 $1^{+}$-Zellen weisen die höchste maximale Wachstumsgeschwindigkeit und Zellzahl auf, während sowohl die maximale Wachstumsgeschwindigkeit als auch Zellzahl der Stro1 ${ }^{+}$-Zellen am geringsten sind. Die Wachstumsgeschwindigkeitskonstanten der CD271+-, CD $133^{+}$- und Stro- $1^{+}$-Zellen zeigen keinen erkennbaren Unterschied. Vergleicht man das Proliferationsverhalten der negativen Zellpopulationen, so wird deutlich, dass die CD271-Zellen die höchste Zellzahl erreichen, obwohl sie die geringste Wachstumsgeschwindigkeitskonstante aufweisen. Die Stro-1'-Zellen proliferieren ähnlich stark wie die CD133-Zellen. Letztere weisen die höchste Wachstumsgeschwindigkeitskonstante auf, gefolgt von den Stro-1'-Zellen. Anhand der Graphen wird deutlich, dass sämtliche Zellpopulationen erst ab dem 3. bis 5 . Versuchstag mit der Proliferation beginnen. Ab dem 6. bis 10. Versuchstag stagniert das Wachstum und es wird eine Plateauphase erreicht.

Die in Abbildung 13 dargestellten Graphen geben die maximalen Wachstumsgeschwindigkeiten der $\mathrm{CD} 271^{+/-}$-, $\mathrm{CD} 133^{+/-}$und der Stro- $1^{+/-}$-Zellen wieder. Darüber hinaus können die genauen Zahlenwerte sowie der Zeitpunkt des maximalen Wachstums der Tabelle 6 entnommen werden. 
Tab. 6: Die Tabelle gibt die maximalen Wachstumsgeschwindigkeiten der Stro- ${ }^{+/-}=\mathrm{CD}_{133^{+/}}$- und $\mathrm{CD} 271^{+/}$-Zellen im osteogenen Differenzierungsmedium wieder. Des Weiteren ist angegeben, zu welchen Zeitpunkten die maximale Wachstumsgeschwindigkeit erreicht wird.

\begin{tabular}{c|cc}
\hline Zelltyp & $\begin{array}{c}\text { Zeitpunkt } \\
\text { (Tag) }\end{array}$ & $\begin{array}{c}\text { Max. Geschwindigkeit } \\
\text { (Zellen/Tag) }\end{array}$ \\
\hline CD133 $^{+}$ & 7,80 & 211.765 \\
CD133 $^{-}$ & 6,67 & 314.736 \\
CD271 $^{+}$ & 6,05 & 484.550 \\
CD271 $^{-}$ & 6,76 & 199.632 \\
Stro-1 $^{+}$ & 7,47 & 80.361 \\
Stro-1 $^{-}$ & 5,34 & 303.371 \\
\hline
\end{tabular}

a)

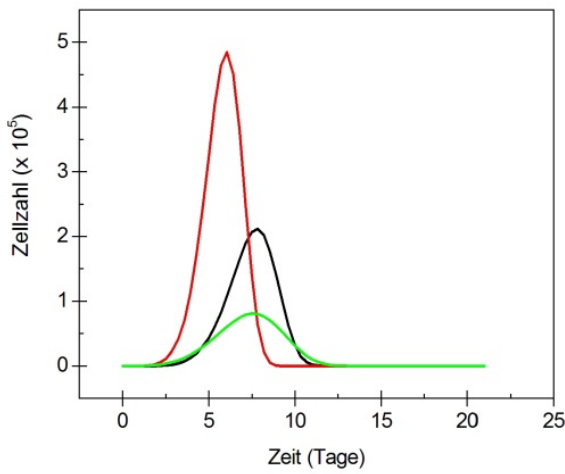

Abb. 13: Abbildung a) zeigt die maximalen Wachstumsgeschwindigkeiten mit entsprechenden Peaks der Stro- $1^{+}$- (grün), CD133 ${ }^{+}$- (schwarz) und $\mathrm{CD} 271^{+}$- (rot) sortierten Zellen und Abbildung b) die maximalen Wachstumsgeschwindigkeiten mit entsprechenden Peaks der Stro-1- (grün), CD133- (schwarz) und CD271- (rot) sortierten Zellen des osteogenen Assays im direkten Vergleich. Die Wachstumsgeschwindigkeit wird gemessen in Zellen/Tag.

Anhand der Graphen der Abbildung 13 und den Daten der Tabelle 6 wird ersichtlich, dass der Zeitpunkt der maximalen Wachstumsgeschwindigkeit für alle Zellpopulationen zwischen Tag fünf und acht des Versuchsablaufs liegt. Die maximale Wachstumsgeschwindigkeit wird gemessen in Zellen/Tag und liegt zwischen 80.361 und 484.550 Zellen/Tag. Die CD133+- und CD133-Zellen unterscheiden sich nur geringfügig bzgl. der maximalen Wachstumsgeschwindigkeit und des entsprechenden Zeitpunkts des Maximums. Die CD133-Zellen erreichen ihre maximale Wachstumsgeschwindigkeit an Tag 6,76 und damit einen Tag eher als die CD133+-Zellen. Die maximale Wachstumsgeschwindigkeit der CD133-Zellen beträgt 314.736 Zellen/Tag und liegt höher als bei den CD133-Zellen (211.765 Zellen).

Bei den CD271 Zellen sind hinsichtlich des Zeitpunkts des Proliferationsmaximums keine deutlichen Unterschiede evident. Beide Populationen erreichen am 6. Ver- 
suchstag die maximale Wachstumsgeschwindigkeit $\left(\mathrm{CD} 271^{+}\right.$-Zellen an Tag 6,05; CD271'-Zellen an Tag 6,76). Die CD271 ${ }^{+}$-Zellen proliferieren mit einer maximalen Wachstumsgeschwindigkeit von 484.550 Zellen/Tag deutlich schneller als die CD271'Zellen (199.632 Zellen/Tag).

Die Zellpopulationen des Stro-1-Ansatzes weisen bzgl. der maximalen Wachstumsgeschwindigkeit und des entsprechenden Zeitpunkts erkennbare Unterschiede auf. Die Stro-1-Zellen proliferieren mit einer maximalen Wachstumsgeschwindigkeit von 303.371 Zellen/Tag deutlich schneller als die Stro- $1^{+}$-Zellen mit maximal 80.361 Zellen/Tag. Die Stro-1'-Zellen erreichen darüber hinaus bereits an Tag 5,34 ihre maximale Wachstumsgeschwindigkeit, während diese von den Stro- $1^{+}$-Zellen erst zwei Tage später (Tag 7,47) erreicht wird.

Im Vergleich der positiv sortierten Zellpopulationen zeigt sich, dass die CD271 ${ }^{+}$-Zellen als erste ihre maximale Proliferationsgeschwindigkeit $(\operatorname{Tag} 6,05)$ erreichen, gefolgt von den Stro- $1^{+}$-Zellen $(7,47)$ und den CD133 ${ }^{+}$-Zellen $(T a g ~ 7,8)$. Die CD271 ${ }^{+}$-Zellen weisen mit 484.550 Zellen/Tag die höchste Wachstumsgeschwindigkeit auf, während die Stro- $1^{+}$-Zellen mit 80.361 Zellen/Tag am langsamsten proliferieren.

Im Vergleich der negativen Zellpopulationen ist zu beobachten, dass die CD133-Zellen genauso schnell proliferieren wie die CD271'-Zellen. Beide Populationen erreichen an Tag 6,76 ihre maximale Wachstumsgeschwindigkeit, während diese von den Stro-1"Zellen bereits einen Tag früher erreicht wird (Tag 5,34). Die CD133-Zellen und die Stro-1'-Zellen weisen mit 314.736 Zellen/Tag (CD133') bzw. 303.371 Zellen/Tag (Stro-1') eine ähnlich hohe Wachstumsgeschwindigkeit auf. Die CD271'-Zellen erreichen mit 199.632 Zellen/Tag eine geringere Wachstumsgeschwindigkeit als die beiden anderen Zellpopulationen. Abbildung 14 zeigt die beobachteten Proliferationsstadien der Stro- $1^{+/-}$-, CD271 $1^{+/}$- und CD $133^{+/-}$-Zellen am 1. 9. und 21. Versuchstag im osteogenen Differenzierungsmedium. 


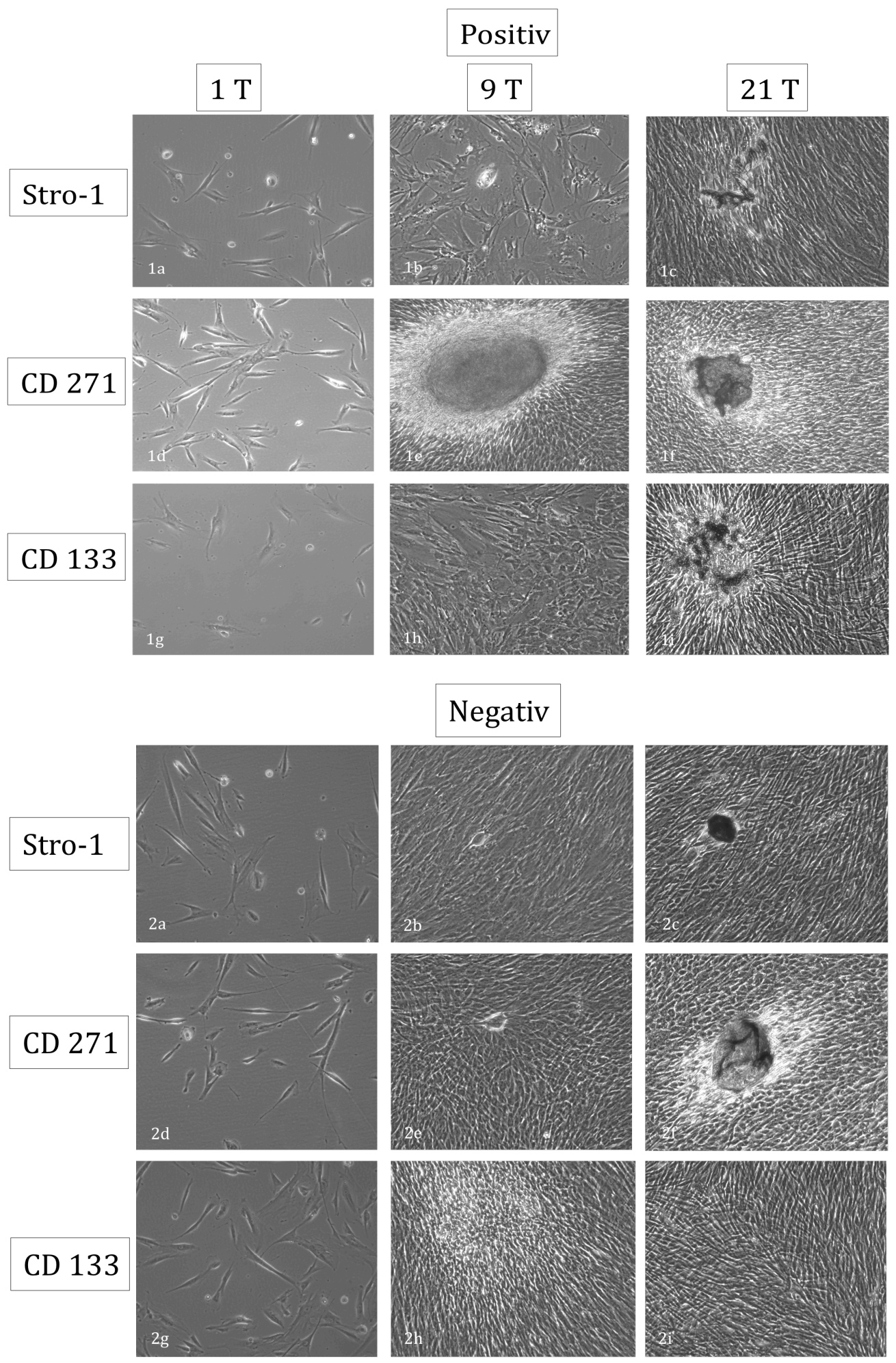

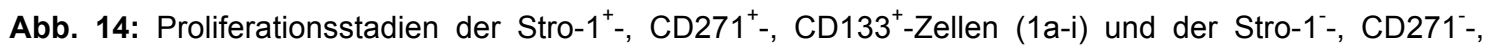
CD133-Zellen (2a-i ) des osteogenen Differenzierungsassays an Tag (T) 1, 9 und 21. Die CD271 ${ }^{+}$-Zellen weisen bereits am 9. Tag erste Mineralisierungen, sogenannte Nodules auf (1e). Am 21. Versuchstag sind in allen positiv sortierten Zellpopulationen Mineralisierungen erkennbar (1c, 1f, 1i). Die Stro-1"-, CD271-, CD133-Zellen zeigen an Tag 9 keine deutlichen Mineralisierungen (2b, 2e, 2h). Am 21. Versuchstag sind bei den Stro1- und CD271- Zellen Nodules zu beobachten (2c, 2f), während die CD133-Zellen keine Nodules vorweisen. (Mikroskop Axiovert 200m/HAL 100, Axiocam MRm, 10-fache Vergrößerung) 


\subsubsection{Proliferationsverhalten im adipogenen Differenzierungs- medium}

Im Rahmen der adipogenen Differenzierungsassays wurden die sortierten Zellpopulationen $\left(\mathrm{CD} 133^{+/}-\right.$, CD271+/-, Stro1 ${ }^{+/}$-Zellen) bis zum Erreichen der Subkonfluenz in Expansionsmedium kultiviert $(C D 133=7$ Tage; CD271 $=4$ Tage; Stro- $1=12$ Tage $)$. Im Anschluss erfolgte die weitere Kultivierung der Zellen mit Adipozytendifferenzierungsmedium. Zu Beginn der Versuchsdurchführung betrug die Zellzahl 50.000 Zellen/Well. An Tag 14 und 28 erfolgte nach dem Ernten eine erneute Bestimmung der Zellzahl mittels CASY. Demzufolge ergaben sich für das Proliferationsverhalten der Zellen des adipogenen Differenzierungsassays drei Messdaten.

Im Folgenden wurde erneut die zeitliche Entwicklung der Zellzahlen der sortierten Zellpopulationen $\left(\mathrm{CD} 133^{+/-}, \mathrm{CD} 271^{+/-}\right.$, Stro- $\left.1^{+/-}\right)$im Verlauf der adipogenen Assays mit dem JMAK-Modell analysiert. Es wird deutlich, dass die beobachteten Dimensionalitäten von 5,5 bis 6,5 reichen (Mittelwert von 6,23 $\pm 0,382$ ). Die Wachstumsgeschwindigkeitskonstante $\mathrm{k}$ variiert je nach genutztem Stammzellenmarker nur vereinzelt und liegt zwischen $8,3 \times 10^{-7}$ und 1,6 $\times 10^{-6}$. Die einzelnen Werte für die Wachstumsgeschwindigkeitskonstante $\mathrm{k}$ und die Dimensionalität $(\operatorname{dim}=\mathrm{n}-1)$ der jeweiligen Zellpopulation sind in Tabelle 7 angegeben. Abbildung 15 zeigt graphisch das Proliferationsverhalten der sortierten Zellpopulationen des adipogenen Assays.

Tab. 7: Die Tabelle gibt die maximale Zellzahl, die Wachstumsgeschwindigkeitskonstante k der Stro- $1^{+/-}$,

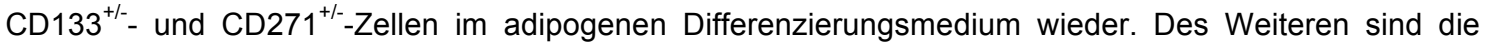
Dimensionalität des Wachstums $(\operatorname{dim}=\mathrm{n}-1)$ und der Bestimmtheitskoeffizient der Regression $\left(\mathrm{R}^{2}\right)$ dargestellt.

\begin{tabular}{c|cccc}
\hline Zelltyp & Max. Zellzahl & K(Tage/Zelle) & dim=n-1 & $\boldsymbol{R}^{\mathbf{2}}$ \\
\hline CD133 $^{+}$ & 325.624 & $8,3 \times 10^{-7}$ & 6,11 & 1 \\
CD133 $^{-}$ & 265.473 & $1,4 \times 10^{-6}$ & 6,43 & 1 \\
CD271 $^{+}$ & 244.636 & $1,3 \times 10^{-6}$ & 6,39 & 1 \\
CD271 $^{-}$ & 262.917 & $1,6 \times 10^{-6}$ & 6,48 & 1 \\
Stro-1 $^{+}$ & 149.199 & $1,03 \times 10^{-6}$ & 5,50 & 1 \\
Stro-1 $^{-}$ & 185.074 & $1,55 \times 10^{-6}$ & 6,48 & 1 \\
\hline
\end{tabular}




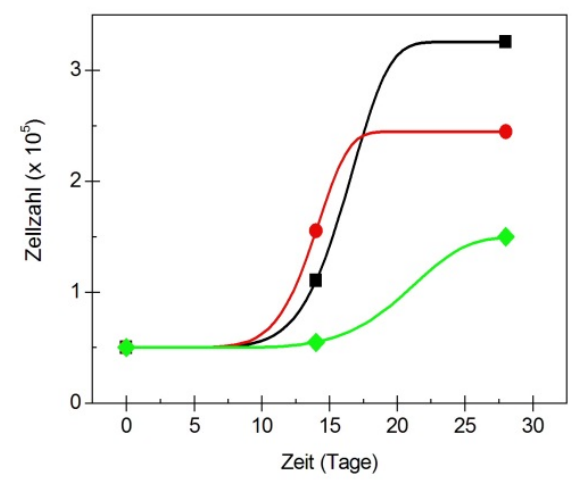

a)

Abb. 15: Abbildung a) zeigt das Proliferationsverhalten der Stro- $1^{+}$(grün), $C D 133^{+}$(schwarz) und CD271 ${ }^{+}$ (rot) - sortierten Zellen, Abbildung b) das Proliferationsverhalten der Stro-1- (grün), CD133-- (schwarz) und CD271- (rot) sortierten Zellen des adipogenen Assays im direkten Vergleich. Angegeben sind für die positiv sortierten Zellen die Mittelwerte (Anzahl der Stichproben = 3).

Die CD271 $1^{+/}$-Zellen zeigen mit einer maximalen Zellzahl von 244.636 Zellen (CD271 ${ }^{+}$) bzw. 262.917 Zellen (CD271') keine erkennbaren Unterschiede in ihrem Proliferationsverhalten. Darüber hinaus weisen sie mit $1,3 \times 10^{-6}$ Tagen/Zelle (CD271 $\left.{ }^{+}\right) \mathrm{bzw}$. $1,6 \times 10^{-6}\left(\mathrm{CD} 271^{-}\right)$ähnliche Wachstumsgeschwindigkeitskonstanten auf. Hinsichtlich der Dimensionalität beider Populationen sind ebenfalls keine deutlichen Unterschiede evident.

Im Vergleich der Stro- $1^{+}$- und Stro-1'-Zellen zeigen sich nur geringfügige Differenzen bzgl. des Proliferationsverhaltens und der Wachstumsgeschwindigkeitskonstanten. Die maximalen Zellzahlen sind mit 149.199 Zellen (Stro-1 ${ }^{+}$) bzw. 185.074 Zellen (Stro-1') ähnlich hoch, ebenso wie die Wachstumsgeschwindigkeitskonstanten der Stro- $1^{+}$Zellen mit $1,03 \times 10^{-6}$ Tagen/Zelle bzw. der Stro-1'-Zellen mit 1,55 × $10^{-6}$ Tagen/Zelle. Die Dimensionalität der Stro- $1^{+}$-Zellen $(5,50)$ ist geringfügig niedriger als die der Stro-1'-Zellen $(6,48)$.

Insgesamt zeigt sich, dass sämtliche Zellpopulationen der adipogenen Ansätze ähnlich hohe Wachstumsgeschwindigkeitskonstanten und Dimensionalitäten aufweisen. Im direkten Vergleich der positiv sortierten Zellpopulationen wird deutlich, dass die CD133+Z-Zellen (325.624 Zellen) am stärksten proliferieren. Sie weisen die höchste maximale Zellzahl und Wachstumsgeschwindigkeit auf, gefolgt von den CD271 ${ }^{+}$-Zellen (244.636 Zellen) und den Stro-1+-Zellen (149.199 Zellen). Ein sichtbarer Anstieg der Proliferation ist bei den CD271 ${ }^{+}$-Zellen ab dem 10. Versuchstag erkennbar, während die CD133+-Zellen ca. ab Tag 12 und die Stro- $1^{+}$-Zellen in etwa ab Tag 15 verstärkt proliferieren. Im Vergleich der negativ sortierten Zellpopulationen wird deutlich, dass die CD133-Zellen und die CD271'-Zellen gleich stark proliferieren, während die 
Stro-1'-Zellen die geringste Zellzahl aufweisen. Alle drei Zellpopulationen beginnen ca. ab dem 10. Versuchstag verstärkt mit der Proliferation. In Bezug auf die Wachstumsgeschwindigkeiten und die Dimensionalitäten sind keine deutlichen Unterschiede evident. Der mittlere Bestimmtheitskoeffizient der Fitfunktionen aller Messungen liegt bei $\mathrm{R}^{2}$ Mittel $=1$. Die in Abbildung 18 dargestellten Graphen zeigen die maximalen Wachstumsgeschwindigkeiten der $\mathrm{CD} 271^{+/-}-, \mathrm{CD} 133^{+/-}$- und der Stro- $1^{+/-}$-Zellen, sowie die entsprechenden Zeitpunkte der maximalen Wachstumsgeschwindigkeit.

Tab. 8: Die Tabelle gibt die maximalen Wachstumsgeschwindigkeiten der Stro-1, CD133 und CD271 positiv und negativ sortierten Zellen im adipogenen Differenzierungsmedium wieder. Des Weiteren ist angegeben, zu welchem Zeitpunkt die maximale Wachstumsgeschwindigkeit während des jeweiligen adipogenen Assays erreicht wird.

\begin{tabular}{c|cc}
\hline Zelltyp & $\begin{array}{c}\text { Zeitpunkt } \\
\text { (Tag) }\end{array}$ & $\begin{array}{c}\text { Max. Geschwindigkeit } \\
\text { (Zellen/Tag) }\end{array}$ \\
\hline CD133 $^{+}$ & 16,6 & 42.519 \\
CD133 $^{-}$ & 13,8 & 41.811 \\
CD271 $^{+}$ & 14,2 & 36.627 \\
CD271 $^{-}$ & 13,3 & 43.079 \\
Stro-1 $^{+}$ & 21,3 & 11.096 \\
Stro-1 $^{-}$ & 13,3 & 27.229 \\
\hline
\end{tabular}

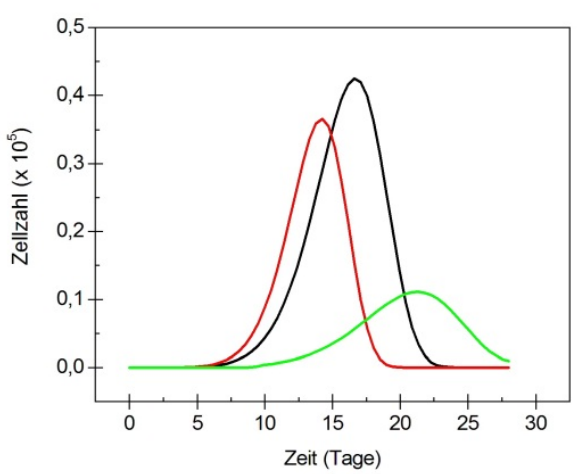

a)

Abb. 16: Abbildung a) zeigt die maximalen Wachstumsgeschwindigkeiten mit entsprechenden Peaks der Stro- $1^{+}$- (grün), CD133 - (schwarz) und CD271 ${ }^{+}$- (rot) sortierten Zellen, Abbildung b) die maximalen Wachstumsgeschwindigkeiten mit entsprechenden Peaks der Stro-1- (grün), CD133-- (schwarz) und CD271- (rot) sortierten Zellen des adipogenen Assays im direkten Vergleich. Die Wachstumsgeschwindigkeit wird gemessen in Zellen/Tag.

Anhand der Tabelle 8 und der Graphen in Abbildung 16 wird deutlich, dass bzgl. der maximalen Wachstumsgeschwindigkeiten keine wesentlichen Unterschiede zwischen den CD133+- (42.519 Zellen/Tag) und den CD133-Zellen (41.811 Zellen/Tag) festzustellen sind. Die CD133'-Zellen erreichen ihre maximale Wachstumsgeschwindigkeit 
allerdings erst an Tag 16,6 und damit ca. drei Tage später als die CD133-Zellen (Tag 13,8).

Die CD $271^{+/}$-Zellen unterscheiden sich ebenfalls nur unwesentlich in ihrem Proliferationsverhalten. Die CD $271^{+}$-Zellen erreichen eine maximale Wachstumsgeschwindigkeit von 36.627 Zellen/Tag, während die CD271'-Zellen mit 43.079 Zellen/Tag geringfügig schneller proliferieren. In Bezug auf den Zeitpunkt der maximalen Wachstumsgeschwindigkeit sind zwischen den beiden Populationen keine deutlichen Unterschiede evident (CD271 ${ }^{+}$-Zellen an Tag 14,2; CD271'-Zellen Tag 13,3).

Die Zellen des Stro-1-Ansatzes unterscheiden sich deutlich hinsichtlich der maximalen Wachstumsgeschwindigkeit und des Zeitpunktes der maximalen Wachstumsgeschwindigkeit. Die Stro- $1^{+}$-Zellen proliferieren mit 11.096 Zellen/Tag deutlich langsamer als die Stro-1'-Zellen (27.229 Zellen/Tag) und erreichen ihre maximale Proliferationsgeschwindigkeit auch erst an Tag 21,3, während die Stro-1'-Zellen diese bereits an Tag 13,3 erreichen.

Im direkten Vergleich der positiven Zellpopulationen wird ersichtlich, dass die CD271 ${ }^{+}$-Zellen am schnellsten ihre maximale Proliferationsgeschwindigkeit erreichen (Tag 14,2), gefolgt von den CD133+-Zellen (Tag 16,6), während die Stro-1 ${ }^{+}$-Zellen ihr Proliferationsmaximum erst an Tag 21,3 erreichen. Ebenso sind bzgl. der maximalen Wachstumsgeschwindigkeit zwischen den CD133+-Zellen (42.519 Zellen/Tag) und den CD271 ${ }^{+}$-Zellen (36.627 Zellen/Tag) nur geringfügige Unterschiede erkennbar. Die Stro- $1^{+}$-Zellen proliferieren mit 11.096 Zellen/Tag allerdings wesentlich langsamer als die beiden anderen Zellpopulationen.

Im Vergleich der Stro-1'-/ CD133-/ CD271'-Zellen wird deutlich, dass alle Zellpopulationen in etwa zum selben Zeitpunkt ( Tag 13) ihre maximale Wachstumsgeschwindigkeit erreichen. Die CD133-Zellen proliferieren mit (41.811 Zellen/Tag) ähnlich schnell wie die CD271'-Zellen mit 43.079 Zellen/Tag. Die Stro-1'-Zellen erreichen hingegen nur eine deutlich langsamere maximale Proliferationsgeschwindigkeit mit lediglich 27.229 Zellen/Tag. Abbildung 17 zeigt die beobachteten Proliferationsstadien der Stro- $1^{+/-}$, $\mathrm{CD} 271^{+/-}$- und $\mathrm{CD} 133^{+/-}$-Zellen am 1. und 28. Versuchstag im adipogenen Differenzierungsmedium. 


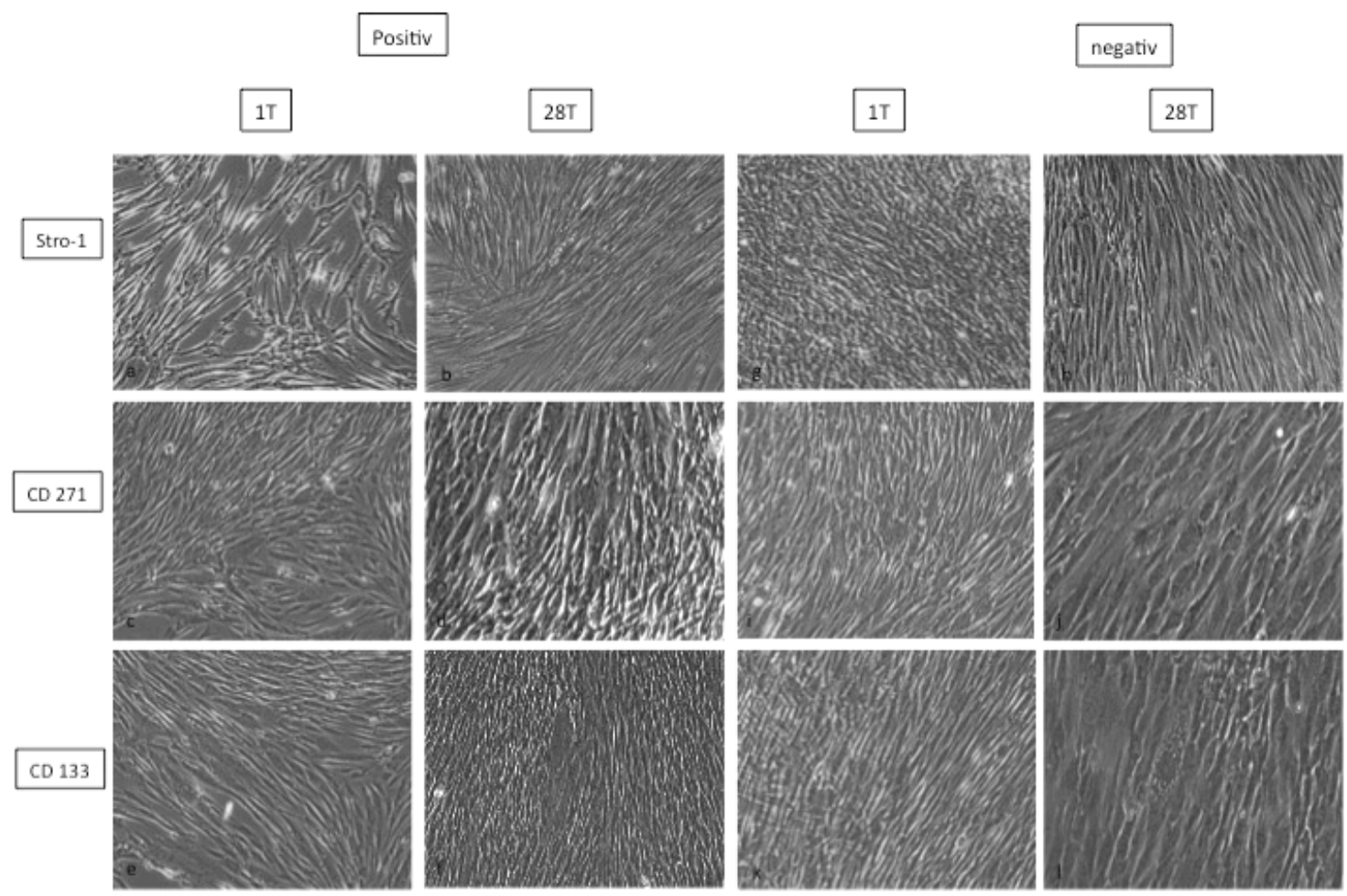

Abb. 17: Die Abbildung zeigt die beobachteten Proliferationsstadien der Stro- $1^{+/-}$, CD $271^{+/-}$- und CD $133^{+/-}$ -Zellen am 1. und 28. Versuchstag $(T)$ im adipogenen Differenzierungsmedium. (Mikroskop Axiovert 200m/HAL 100, Axiocam MRm, 10-fache Vergrößerung)

\subsection{Differenzierung der Zahnkeimzellen}

\subsubsection{Osteogene Differenzierung}

Die osteogenen Differenzierungsassays wurden über einen Zeitraum von 21 Tagen durchgeführt. Die $\mathrm{CD} 133^{+/-}$, $\mathrm{CD} 271^{+/}-$, Stro- ${ }^{+/-}$-Zellen wurden jeweils fünf Tage im Expansionsmedium und für die restliche Versuchsdauer im osteogenen Differenzierungsmedium kultiviert. Im Rahmen des Mediumwechsels wurde an acht Versuchstagen $1 \mathrm{ml}$ Überstand/Well genommen und im Anschluss mittels ELISA auf dessen Osteocalcinkonzentration untersucht, wodurch sich dementsprechend acht Messdaten ergaben. Die Zellzahl betrug zu Beginn der Versuchsdurchführung 50.000 Zellen/Well. An Tag 5, 9 und 21 erfolgte nach dem Ernten der Zellen eine erneute Bestimmung der Zellzahl mittels CASY, woraus sich vier Messdaten ergaben.

In den folgenden Abbildungen sind die durchgeführten OCN-ELISA sowie das Proliferationsverhalten der jeweiligen sortierten Zellpopulationen $\left(\mathrm{Stro}^{-1^{+/}}, \mathrm{CD} 133^{+/}\right.$, CD271 ${ }^{+/}$) des osteogenen Differenzierungsassays graphisch dargestellt. Der OCNELISA sowie die Zellzählung mittels CASY konnten problemlos durchgeführt werden. 
Die Proliferation und $\mathrm{OCN}-$ Konzentration der Stro- $1^{+}$- und Stro-1-Zellen ist in Abbildung 18 dargestellt.

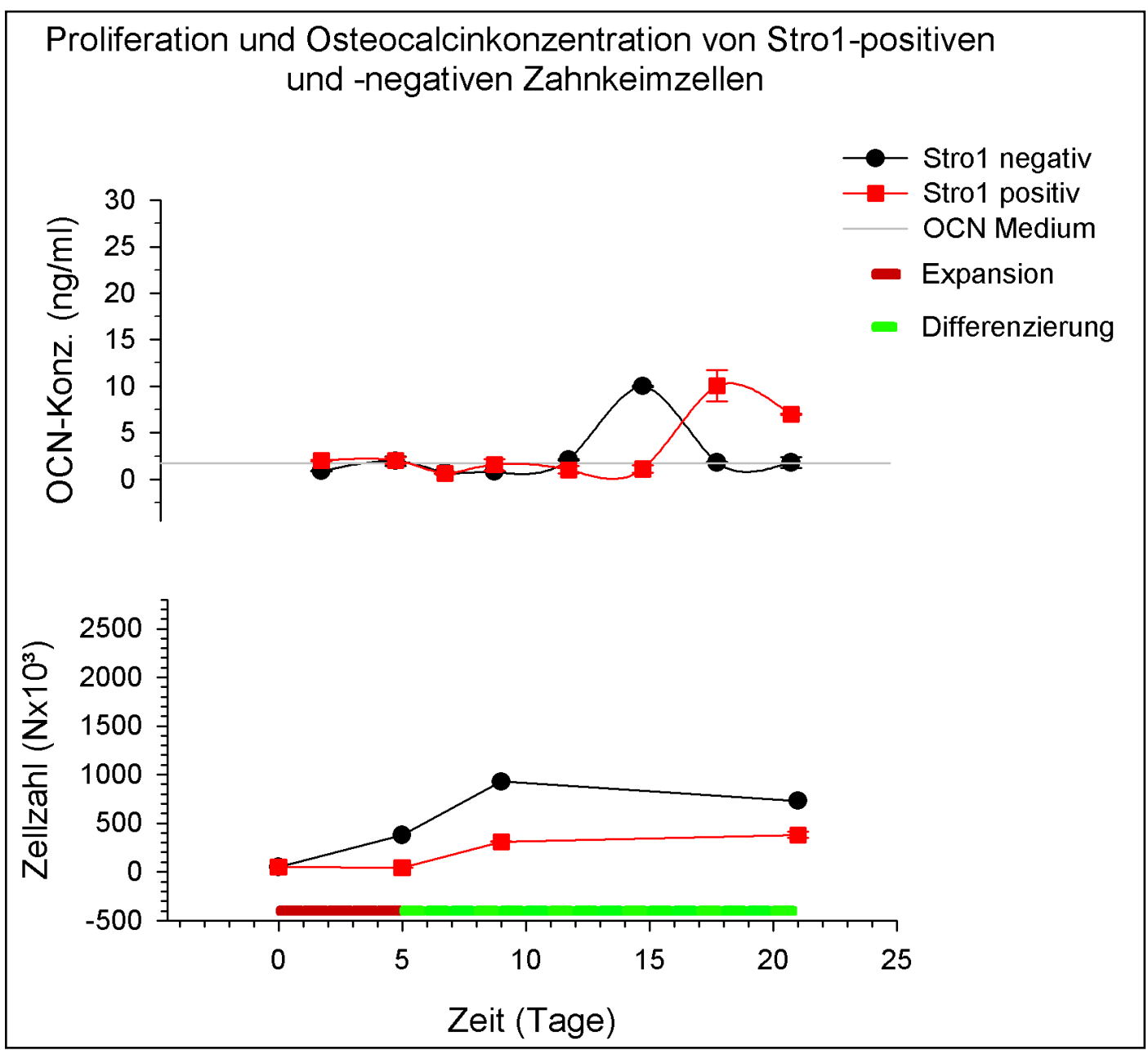

Abb. 18: Es sind die OCN-Konzentration und das Proliferationsverhalten der Stro- $1^{+/}$-Zellen des osteogenen Differenzierungsassays dargestellt. (OCN = Osteocalcin)

Die Proliferation steigt ab dem 5. Tag der Versuchsdauer an. Die Stro-1'-Zellen zeigen ein stärkeres Wachstum als die Stro- $1^{+}$-Zellen. Beide Zellpopulationen erreichen an Tag 15 (Stro1') bzw. 16 (Stro1 $\left.{ }^{+}\right)$etwa zeitgleich den Höhepunkt ihrer Proliferation. $\mathrm{Ab}$ diesen Zeitpunkten ist eine Abnahme der Zellzahlen zu beobachten. Insgesamt proliferieren die Stro- $1^{-}$-Zellen etwas stärker als die Stro- $1^{+}$-Zellen. Die Osteocalcinkonzentration befindet sich bis Tag 12 des Versuchsablaufs sowohl bei den Stro ${ }^{+}$Zellen als auch bei den Stro1-Zellen konstant im Bereich der OCN-Konzentration des Mediums. Ab Tag 12 ist bei den Stro-1'-Zellen ein Anstieg der OCN-Konzentration zu beobachten, dessen Peak sich an Tag 15 befindet. Anschließend fällt die OCNKonzentration wieder in den Bereich des Ausgangswerts zurück. Die Stro- $1^{+}$-Zellen scheinen ab Tag 15 verstärkt Osteocalcin zu sezernieren. Die OCN-Konzentration erreicht ihren Peak an Tag 18, gefolgt von einem geringen Abfall. Es besteht zwischen 
den Stro- $1^{+}$- und den Stro-1-Zellen kein sichtbarer Unterschied hinsichtlich der Höhe der OCN-Konzentration. Die Stro- $1^{+}$-Zellen beginnen allerdings drei Tage später mit der verstärkten OCN-Sekretion, wodurch der Peak um drei Tage zeitversetzt ist. Der Anstieg der OCN-Konzentration korreliert mit dem Proliferationsverhalten der Zellpopulationen.

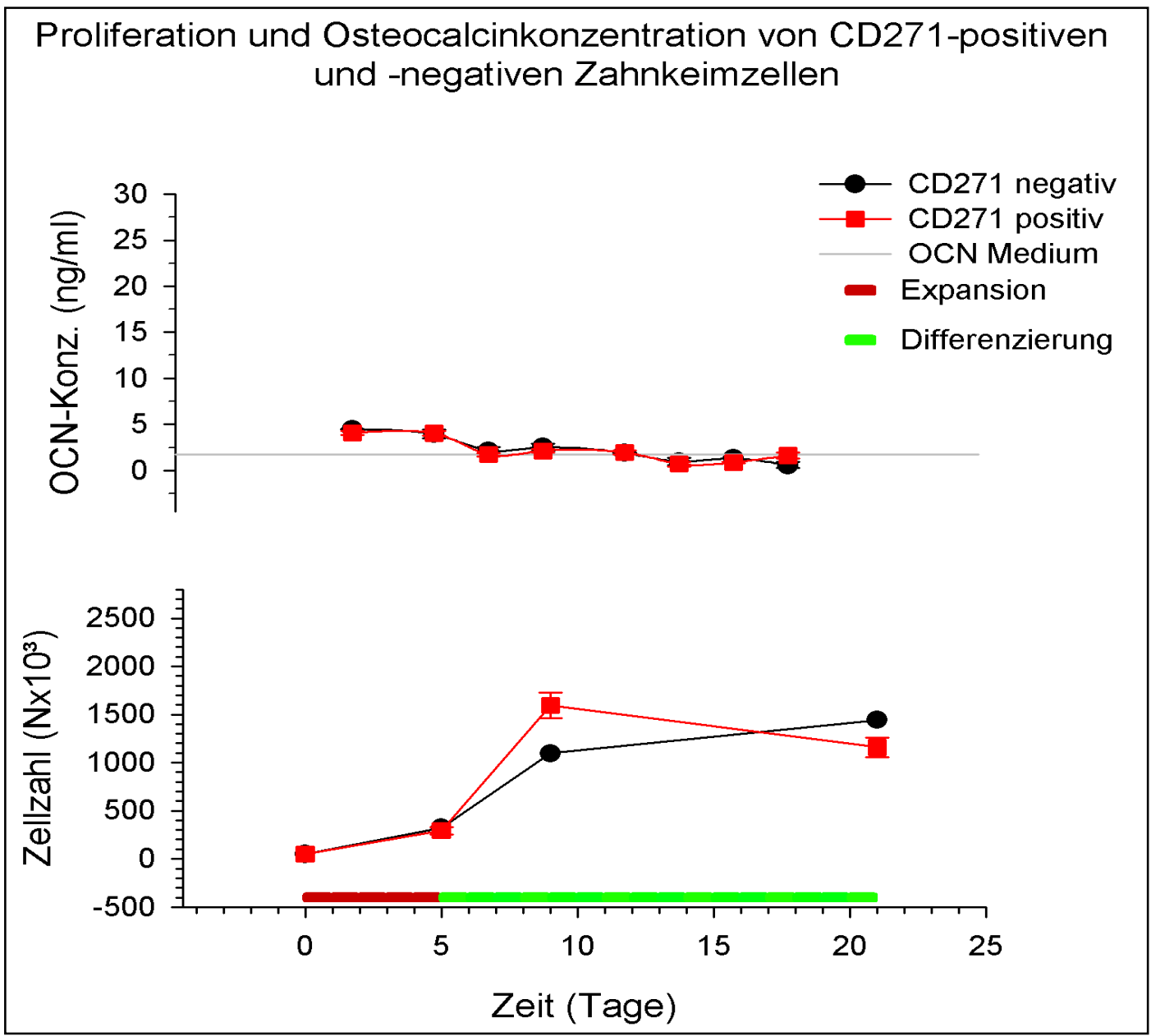

Abb. 19: Es sind die OCN-Konzentration und das Proliferationsverhalten der CD271 ${ }^{+/}$-Zellen des osteogenen Differenzierungsassays dargestellt. (OCN = Osteocalcin).

Die Proliferation und OCN-Konzentration der CD271+/- ist in Abbildung 19 dargestellt. Die Proliferation der CD271+- und CD271-Zellen nimmt ab dem 5. Versuchstag zu, wobei die CD271 ${ }^{+}$-Zellen etwas schneller proliferieren. Sie erreichen den Höhepunkt ihres Wachstums an Tag 14. Anschließend nimmt die Zahl der CD271 ${ }^{+}$-Zellen wieder ab. Die Wachstumskurve der CD271'-Zellen verläuft ähnlich. Allerdings befindet sich der Peak der Proliferation erst an Tag 16. Insgesamt zeigt sich kein sichtbarer Unterschied bzgl. des Proliferationsverhaltens zwischen den genannten Zellpopulationen. 
Die OCN-Konzentration der CD271 ${ }^{+}$- und $\mathrm{CD} 271^{-}$-Zellen befindet sich während der gesamten Versuchsdauer im Bereich der OCN-Konzentration des Mediums. Es findet bei keiner der beiden Zellpopulationen ein erkennbarer Anstieg der OCN-Konzentration statt. Es ist hinsichtlich der Osteocalcinsekretion kein Unterschied zwischen den CD271 ${ }^{+}$-und CD271-Zellen festzustellen.

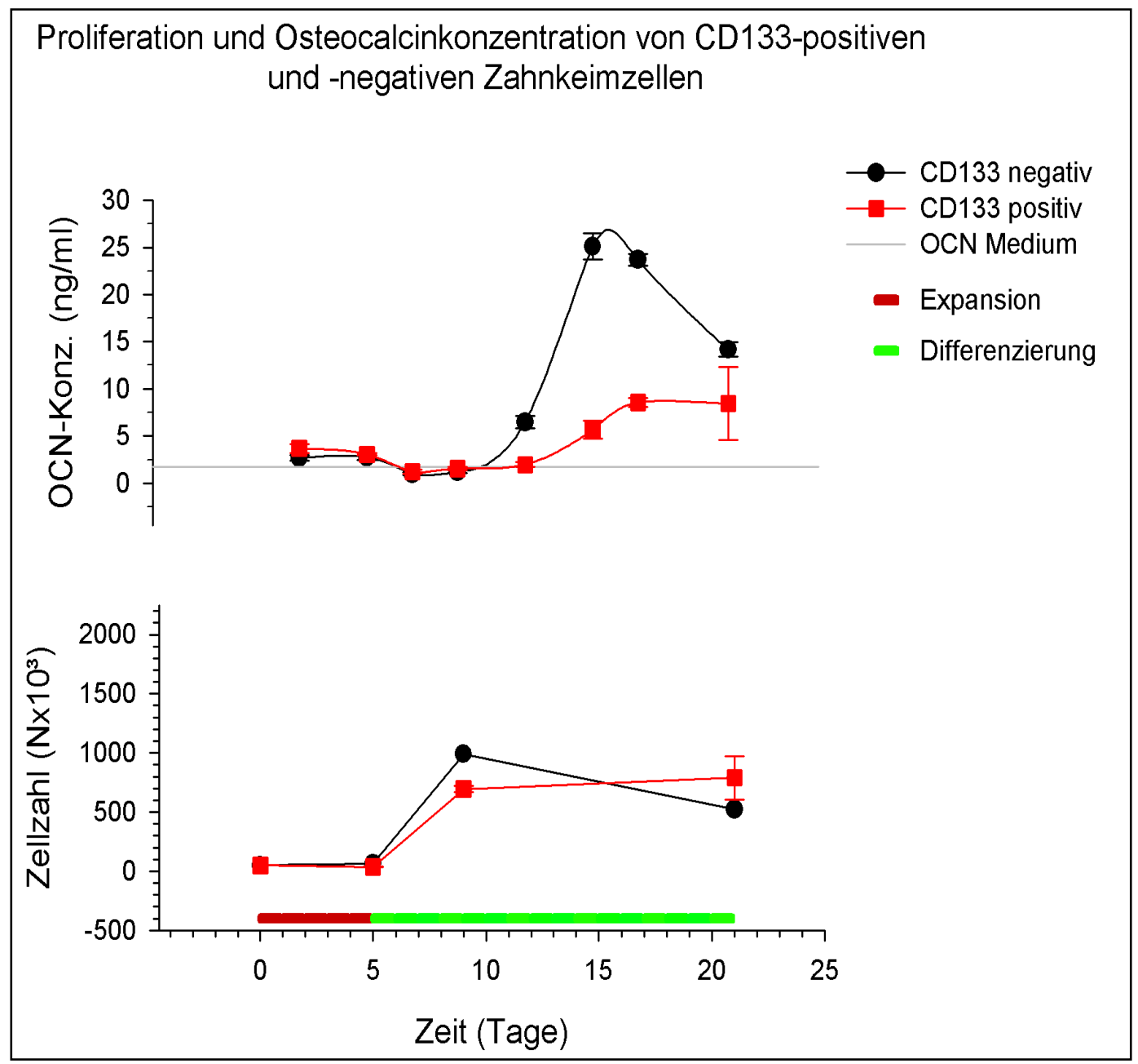

Abb. 20: Es sind die OCN-Konzentration und das Proliferationsverhalten der CD133 $3^{+/-}$-Zellen des osteogenen Differenzierungsassays dargestellt. (OCN = Osteocalcin).

Anhand Abbildung 20 ist zu erkennen, dass ab dem 5. Versuchstag sowohl bei den CD133"- als auch bei den CD133-Zellen ein Anstieg in der Proliferation zu beobachten ist. Der Peak des Zellwachstums befindet sich bei beiden Populationen an Tag 15 bis 16. Im Anschluss nimmt die Zellzahl wieder ab. Die CD133-Zellen proliferieren im Bereich des Peaks stärker als die CD133'-Zellen. Insgesamt wird aber kein Unterschied zwischen den einzelnen Zellpopulationen in Bezug auf ihr Proliferationsverhalten deutlich. 
Die OCN-Konzentrationen der CD133+- und der CD133-Zellen befinden sich bis Tag 10 des Versuchsablaufs im Bereich der OCN-Konzentration des Mediums. Ab Tag 10 wird ein Anstieg der OCN-Konzentration sichtbar, wobei die OCN-Konzentration der CD133-Zellen stärker zunimmt als die der CD133'-Zellen. Bei letzteren steigt die Osteocalcinsekretion stetig an und stagniert ab Tag 15. Die OCN-Konzentration der CD133-Zellen erreicht an Tag 15 ihren Peak und sinkt anschließend wieder ab. Insgesamt liegt die OCN-Konzentration bei den CD133-Zellen höher als bei den CD133-Zellen.

Zur Charakterisierung der Zahnkeimzellen und zur Überprüfung, ob die isolierten Populationen multipotente Stammzellen beinhalten, erfolgte eine molekularbiologische Aufarbeitung der geernteten Zahnkeimzellen. Zum Nachweis einer Multipotenz wurden die Zellen bzgl. ihres osteogenen, adipogenen und chondrogenen Differenzierungspotentials mittels PCR und teilweise RTq-PCR analysiert. Es wurden jeweils Primer für solche Gene eingesetzt, deren erhöhte Expression für die entsprechend differenzierten Zellen charakteristisch sind. Das Stoffwechsel-Gen Glycerinaldehyd-3-PhosphatDehydrogenase (GAPDH) diente als positive Kontrolle zum Nachweis von cDNA. Die PCR und RTq-PCR stellen reproduzierbare Verfahren zur Analyse der Expression von Markergenen auf Transkriptebene dar und sind hochspezifisch.

Zum Nachweis osteogen differenzierter Zellen wurde die Expression von Osteocalcin, Osteopontin, Osteocrin, Osteonectin, Kollagen Typ I alpha1 (Col1A1) und „core binding factor alpha 1“ (Cbfa1) der einzelnen Zellpopulationen (Stro- $1^{+/-}, \mathrm{CD} 271^{+/}, \mathrm{CD} 133^{+/}$) analysiert. Abbildung 21 zeigt die elektrophoretische Auftrennung der mittels PCR amplifizierten cDNAs der genannten Markergene auf einem Agarose-Gel (1,5\%ig).

Aus Abbildung 21 geht hervor, dass Osteocalcin, Osteopontin und Osteonectin von sämtlichen isolierten Zellpopulationen exprimiert werden. Gleiches gilt für die Expression von Col1A1 und Cbfa1. Eine erkennbare Expression des osteogenen Markers Osteocrin kann jeweils in einem Ansatz der Stro- $1^{+}-$, CD $133^{+}-$und CD271 $1^{+}$-Zellen beobachtet werden, während bei den Stro-1-, den CD271-, und den CD133-Zellen keine deutliche Expression des Markers evident ist. Des Weiteren sind vermehrt Nebenbanden zu beobachten. Weder zwischen den einzelnen Stammzellmarkern, noch bzgl. der positiv und negativ sortierten Zellen, sind Unterschiede im Expressionsverhalten für die oben aufgeführten osteogenen Marker erkennbar. Lediglich hinsichtlich des Expressionsmusters von Osteocrin zeigen sich Unterschiede zwischen den positiv bzw. negativ sortierten Zellpopulationen, da Osteocrin ausschließlich von einem Teil der positiv sortierten Zellen exprimiert wird. 


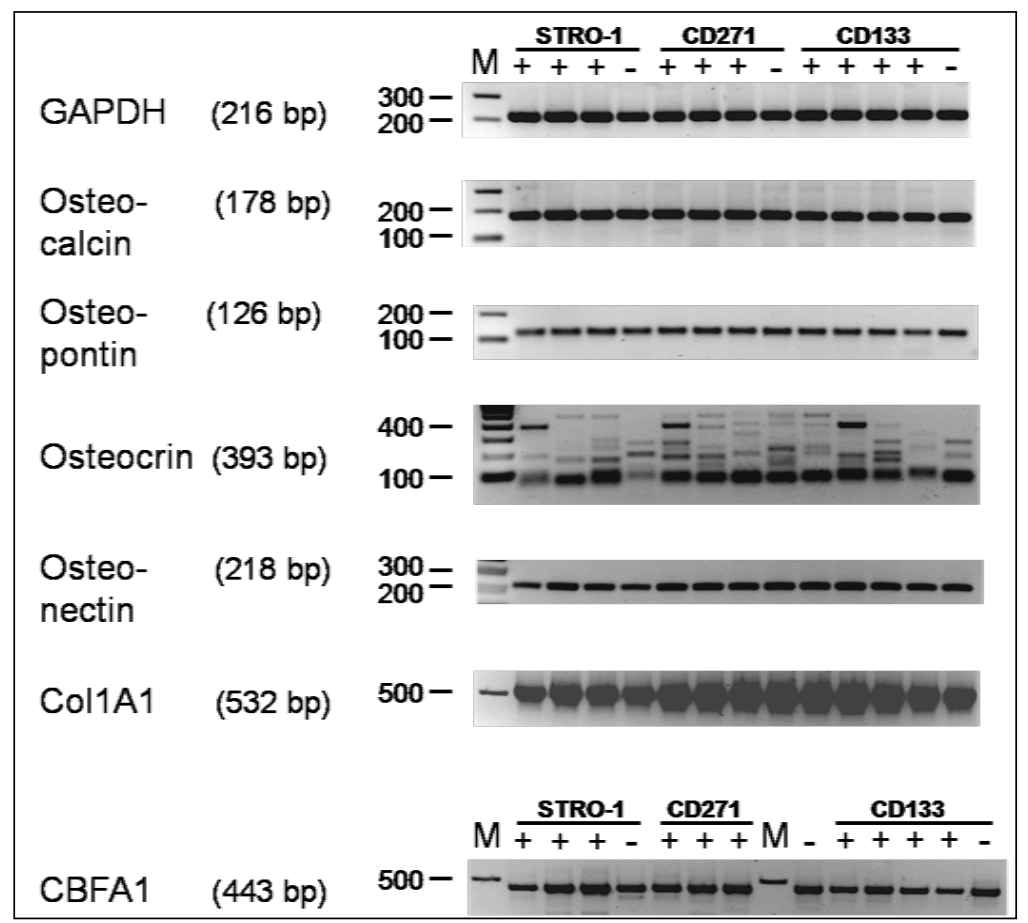

Abb. 21: Die Abbildung zeigt die Expression osteogener Differenzierungsmarker (Osteocalcin, Osteocrin, Osteopontin, Osteonectin, Col1A1, Cbfa1) und des „housekeeping“-Gens GAPDH mittels PCR nach

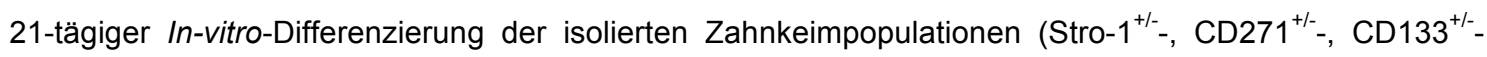
sortierte Zellen) im Osteoblastendifferenzierungsmedium ( $\mathrm{bp}=$ Basenpaare; $\mathrm{M}=$ Marker).

Abbildung 22 zeigt die Osteocalcin-Expression der Stro- $1^{+/-}$, CD $271^{+/-}$- und CD $133^{+/}$Zellen des osteogenen Assays anhand einer RTq-PCR an Tag 0, 4 und 16 der Differenzierung. An Tag 0 und 4 findet nur eine geringfügige OCN-Expression der Stro- $1^{+/-}$Zellen statt. Erst an Tag 16 weisen beide Zellpopulationen einen deutlichen Anstieg der OCN-Expression auf, wobei die Stro- $1^{+}$-Zellen mehr als doppelt so viel OCN exprimieren wie die Stro-1-Zellen. Die Expression von OCN der negativ sortierten CD133-Zellen fällt an Tag 0, 4 und 16 deutlich höher aus als die der CD133'-Zellen. Es ist zu beobachten, dass die positiv sortierten CD133-Zellen an Tag 0 und 4 nur geringfügig OCN exprimieren und die Expression erst am 16. Versuchstag deutlich ansteigt. Dieses ist ebenso bei den Stro- $1^{+/}$-Zellen zu beobachten. Die CD271+/-Zellen zeigen zu keinem Zeitpunkt eine deutlich erhöhte $\mathrm{OCN}-$ Expression. Insgesamt weisen die Stro- $1^{+}$-Zellen die höchste OCN-Expression auf, gefolgt von den CD133-Zellen und CD133'-Zellen. Die CD133Zellen zeigen als einzige Population bereits an Tag 0 und 4 erhöhte OCN-Werte. 


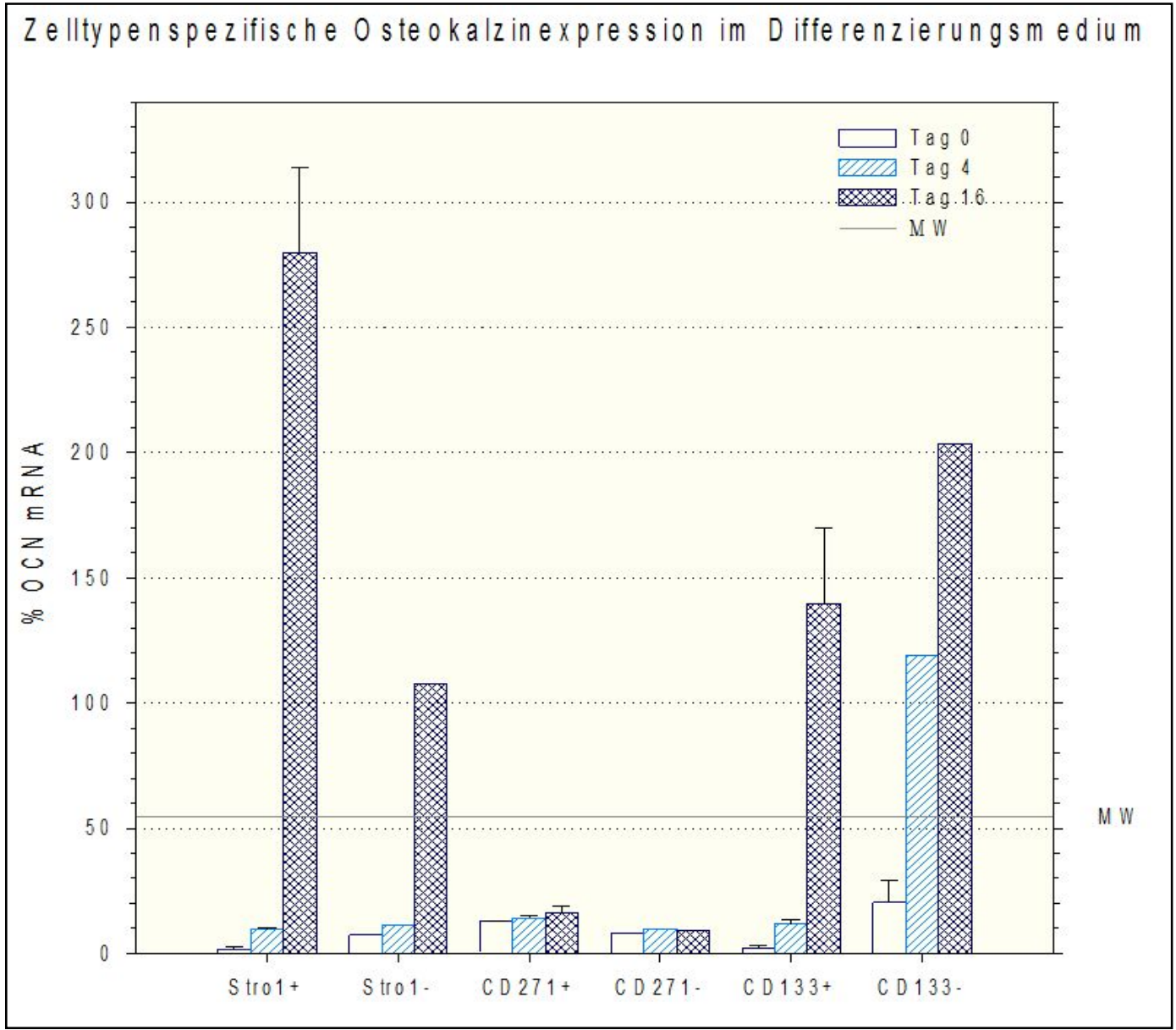

Abb. 22: Expression des osteogenen Differenzierungsmarkers Osteocalcin anhand einer RTq-PCR nach fünftägiger Kultivierung im Expansionsmedium und anschließender 16-tägiger In-vitro-

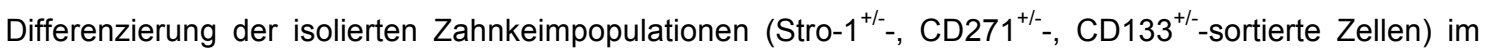
Osteoblastendifferenzierungsmedium (MW = Mittelwert).

\subsubsection{Chondrogene Differenzierung}

Die Durchführung des chondrogenen Differenzierungsassays erfolgte nach den in „Material und Methoden“ beschriebenen Bedingungen über einen Zeitraum von 33 Tagen. Die chondrogene Differenzierung der Zellen wurde mittels PCR anhand des Expressionsmusters der chondrogenen Differenzierungsmarker Aggrecan und Chondroadherin sowie des Transkriptionsfaktors Sox9 analysiert. Das „housekeeping“Gen GAPDH dient zum Nachweis von cDNA und wird von allen Zellpopulationen exprimiert. Abbildung 23 zeigt die Expression des „housekeeping“-Gens GAPDH mittels PCR nach 33-tägiger In-vitro-Differenzierung der isolierten Zahnkeimpopulationen $\left(\right.$ Stro- $1^{+/} / \mathrm{CD} 271^{+/} / \mathrm{CD} 133^{+/-}$sortierten Zellen) im Chondrozytendifferenzierungsmedium. 


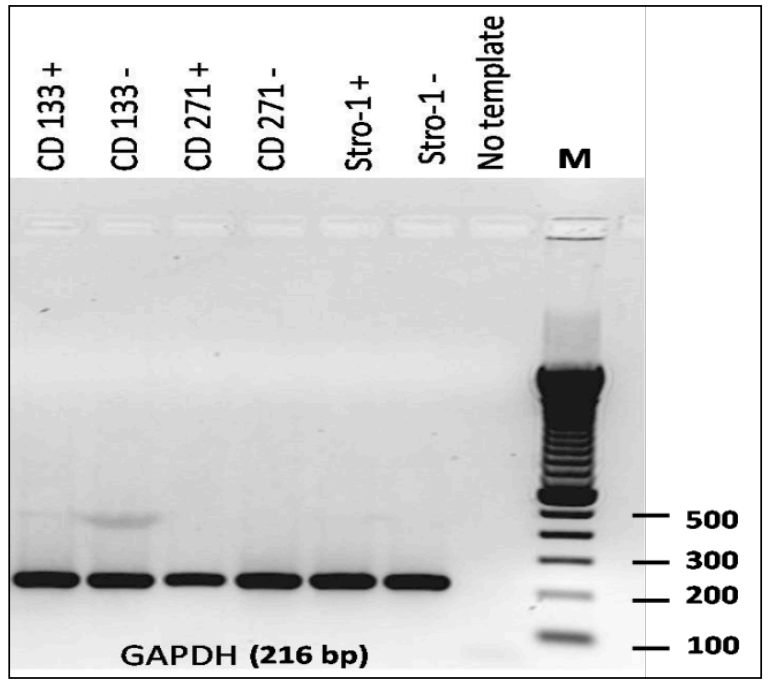

Abb. 23: Expression des „housekeeping“-Gens GAPDH mittels PCR nach 33-tägiger In-vitroDifferenzierung der isolierten Zahnkeimpopulationen (Stro- $1^{+/-}$, CD271 ${ }^{+/-}$, CD133 ${ }^{+/-}$-sortierte Zellen) im Chondrozytendifferenzierungsmedium ( $b p=$ Basenpaare, $M=$ Marker).

Abbildung 24 zeigt die Expression des chondrogenen Differenzierungsmarkers Aggrecan. Eine deutliche Expression dieses chondrogenen Markers kann jeweils bei den Stro- $1^{+}$-, den CD133- und den CD271-Zellen beobachtet werden. Die Stro-1'- und die CD133'-Zellen zeigen eine leichte Expression von Aggrecan, während bei den CD271 $1^{+}$-Zellen keine Expression des Markers evident ist. Der Transkriptionsfaktor Sox9 wird von den $\mathrm{CD}_{133^{+/}}$- und Stro- ${ }^{+/-}$-Zellen exprimiert. Die CD271-Zellen weisen ebenfalls eine deutliche Expression von Sox9 auf, während der Marker von den CD271 ${ }^{+}$-Zellen nur schwach exprimiert wird.

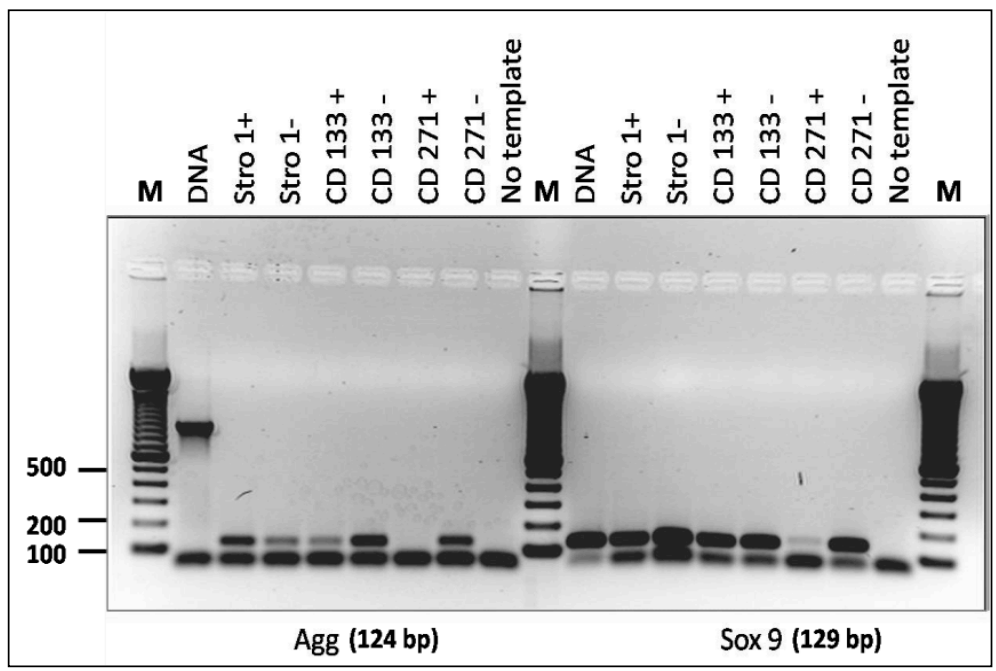

Abb. 24: Expression des chondrogenen Differenzierungsmarkers Aggrecan (Agg) und des Transkriptionsfaktors Sox9 mittels PCR nach 33-tägiger In-vitro-Differenzierung der isolierten Zahnkeimpopulationen $\left(\right.$ Stro- $1^{+/-}$-, CD271 ${ }^{+/-}$-, CD133 ${ }^{+/}$-sortierte Zellen) im Chondrozytendifferenzierungsmedium. DNA dient zur Kontrolle der Primer (bp = Basenpaar; $\mathrm{M}=$ Marker). 
Abbildung 25 zeigt die Expression des chondrogenen Differenzierungsmarkers Chondroadherin. Der Marker wird von den Stro- $1^{+/-}$- und den $\mathrm{CD} 133^{+/-}$-Zellen, sowie von den CD271'-Zellen exprimiert. Die CD271 ${ }^{+}$-Zellen weisen keine Expression von Chondroadherin auf.

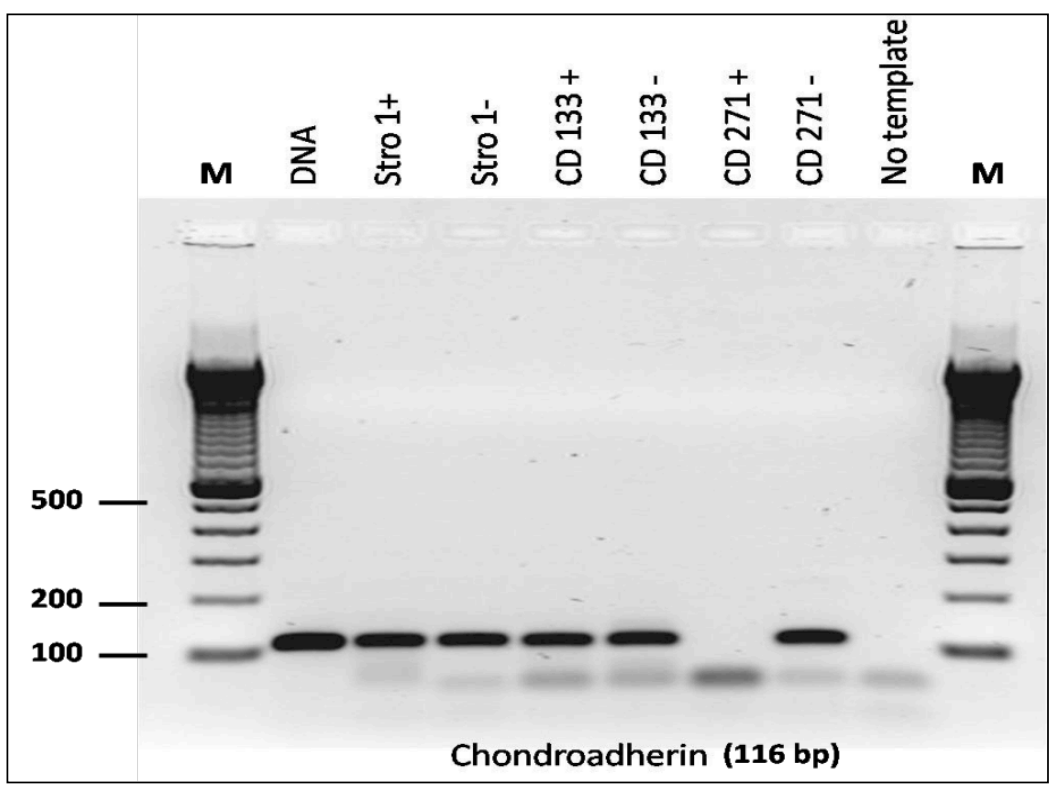

Abb. 25: Expression des chondrogenen Differenzierungsmarkers Chondroadherin mittels PCR nach 33-tägiger In-vitro-Differenzierung der isolierten Zahnkeimpopulationen (Stro-1 ${ }^{+/}-$, CD271 $1^{+/}$-, $\mathrm{CD}_{133^{+/}}$sortierte Zellen) im Chondrozytendifferenzierungsmedium. DNA dient zur Kontrolle der Primer ( $b p=B a-$ senpaare, $M=$ Marker)

\subsubsection{Adipogene Differenzierung}

Die Expression verschiedener Differenzierungsmarker im Adipozytendifferenzierungsmedium ist in Abbildung 26 anhand einer PCR dargestellt. Die Abbildung zeigt die Expression von PPAR $\gamma$, FABP4, Osteopontin, Col1A1, Cbfa1 und Chondroadherin nach 14- bzw. 28-tägiger In-vitro-Differenzierung. Zum Nachweis einer adipogenen Differenzierung der Zellen wurde die Expression von „peroxisome proliferator-acitvated receptor" (PPAR $\gamma$ ) und „Fatty acid binding protein 4“ (FABP4) der einzelnen Zellpopulationen untersucht. PPAR $\gamma$ wird von allen Zellpopulationen sowohl an Tag 14 als auch an Tag 28 gleichmäßig exprimiert. Eine schwache Expression des adipogenen Differenzierungsmarkers FABP4 kann bei den Stro- $1^{+}$-Zellen nach 14 Tagen, sowie bei den CD133'-Zellen sowohl nach 14- als auch 28-tägiger Differenzierung nachgewiesen werden. Die CD271 $1^{+/}$-Zellen exprimieren zu keinem Zeitpunkt FABP4. Der Abbildung 26 ist ebenfalls die Expression der osteogenen Differenzierungsmarker Osteopontin, Col1A1 und des Transkriptionsfaktors Cbfa1 zu entnehmen. Sämtliche Marker werden von den Stro- $1^{+/-}$-, CD $133^{+/-}$- und CD271 $1^{+/}$-Zellpopulationen zu beiden Zeitpunkten ex- 
primiert. Ebenso ist die Expression des chondrogenen Markers Chondroadherin bei allen Zellfraktionen nach 14 bzw. 28 Tagen evident.

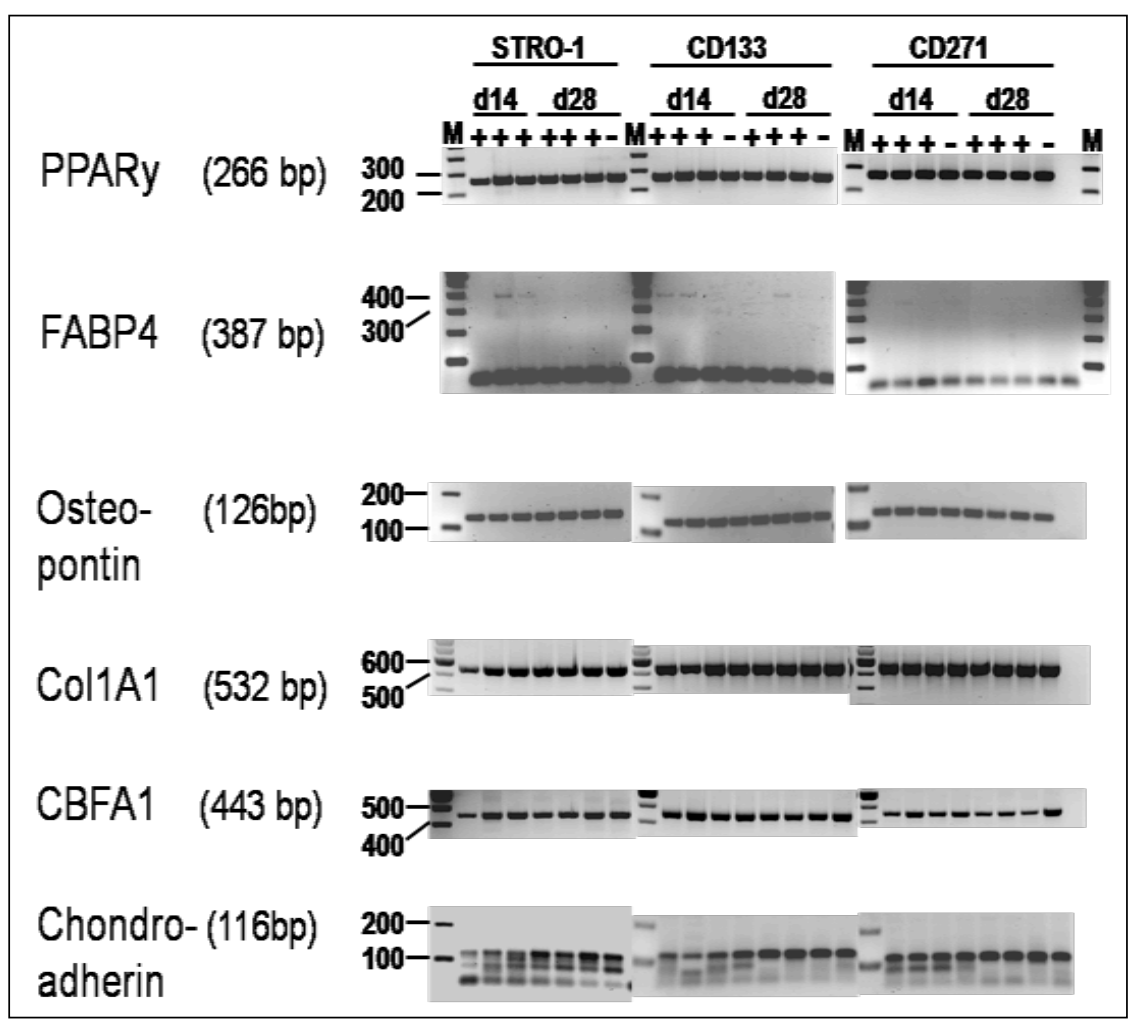

Abb. 26: Expression verschiedener Differenzierungsmarker (PPAR $\gamma$, FABP4, Osteopontin, Col1A1, Cbfa1, Chondroadherin) mittels PCR nach In-vitro-Differenzierung der isolierten Zahnkeimpopulationen (Stro- $1^{+/-}$,

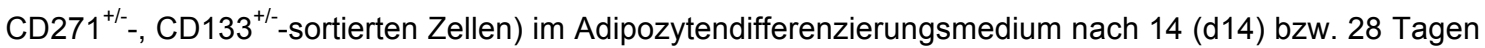
(d28) $(\mathrm{bp}=$ Basenpaare, $\mathrm{d}=$ Tag, $\mathrm{M}=$ Marker $)$.

Als histologischer Nachweis einer adipogenen Differenzierung der Zahnkeimzellen wurde eine ÖI-Rot-O-Färbung der fixierten Zellen nach 14- bzw. 28-tägiger Differenzierung durchgeführt und ist in Abbildung 27 dargestellt. Diese Färbung ist spezifisch für Lipidvakuolen, welche im Lichtmikroskop rot erscheinen.

Die Stro- $1^{+}$-Zellen zeigen nach 14-tägiger Differenzierung keinerlei Lipidvakuolen, während nach 28 Tagen eine deutliche Akkumulation kleiner Lipidvakuolen im Zytoplasma der Zellen zu beobachten ist. Es handelt sich dabei nicht um reife Adipozyten, sondern eher um Zellen im Stadium eines Präadipozyten. Die negativ sortierten Stro-1-Zellen zeigen nach 14 Tagen keine positive Öl-Rot-O-Färbung. Nach 28 Tagen sind ganz vereinzelt Präadipozyten mit kleinen lipidgefüllten Vesikeln erkennbar. Die CD271 ${ }^{+/}$und $\mathrm{CD} 133^{+/}$-Zellen weisen nach 14- und 28-tägiger Differenzierung nur kleine Lipidvakuolen auf. Es ist jedoch zu beobachten, dass die CD271'-Zellen nach 14 Tagen eine ähnlich deutlich positive Öl-Rot-O-Färbung aufweisen wie die Stro- $1^{+}$-Zellen nach 28 Tagen. Zusammenfassend lässt sich sagen, dass zwar alle Zellpopulationen 
nach 28-tägiger Inkubation im adipogenen Differenzierungsmedium kleine Lipidvesikel bilden, aber lediglich die Stro-1 ${ }^{+}$-Zellen nach 28 Tagen und die CD271'-Zellen nach 14 Tagen eine deutlich positive Öl-Rot-O-Färbung aufweisen.

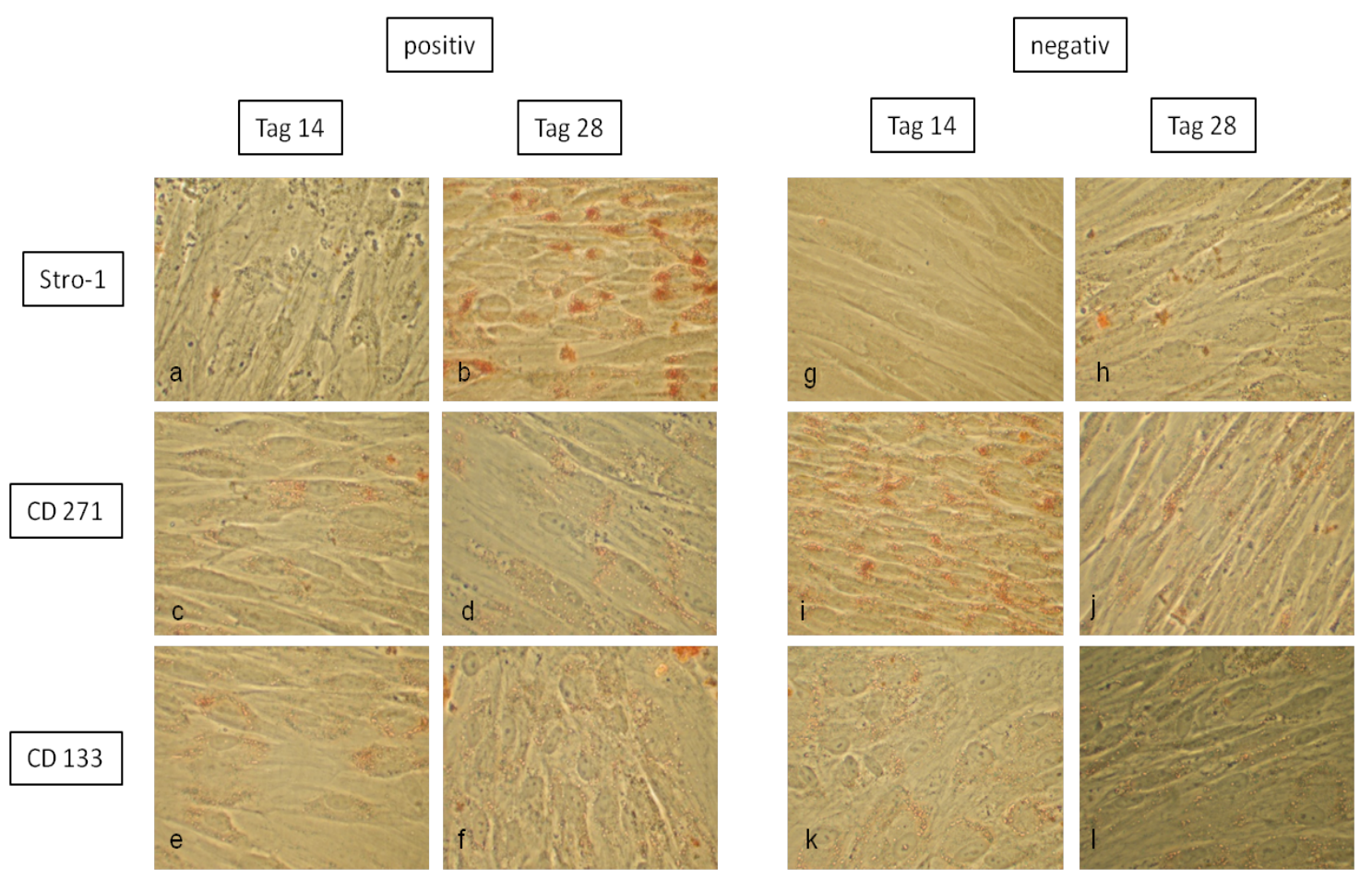

Abb. 27: Öl-Rot-O-Färbung der Zahnkeimzellen des adipogenen Assays. Dargestellt sind die Stro- $1^{+/-}$, $\mathrm{CD} 271^{+/-}$- und $\mathrm{CD} 133^{+/-}$-Zellen nach 14- bzw. 28-tägiger Differenzierung im adipogenen Differenzierungsmedium. (Mikroskop Axiovert 200m/HAL 100, Axiocam MRm,10-fache Vergrößerung) 


\section{Diskussion}

Gegenstand der vorliegenden Arbeit war die Untersuchung und Charakterisierung des Proliferations- und Differenzierungspotentials der Pulpazellen von Zahnkeimen. Zur Überprüfung, ob die Population der Zahnkeimzellen multipotente Stammzellen beinhaltet, wurden im Zuge dieser Untersuchung kultivierte Zahnkeimzellen mithilfe von Stammzellmarkern (Stro-1, CD 271, CD 133) sortiert. Im Anschluss an die Sortierung wurde untersucht, ob die selektierten Zellen mittels unterschiedlicher Differenzierungsmedien zu Fett- (Adipozyten), Knorpel- (Chondrozyten) und Knochenzellen (Osteozyten) differenzieren können. Da diese Zelltypen nicht im Zahngewebe vorkommen, wäre ihr Nachweis ein Hinweis auf eine Multipotenz der Zahnkeimzellen. Zur Kontrolle, ob im Rahmen der Differenzierungsversuche tatsächlich Adipozyten, Chondrozyten und Osteozyten entstanden sind, erfolgte eine molekularbiologische Aufarbeitung der Zellen zu definierten Zeitpunkten. Es wurde mittels Polymerase-KettenReaktion und quantitativer Real-Time PCR die Expression bestimmter Markergene analysiert, welche typischerweise von den einzelnen Zelltypen exprimiert werden. Weiterhin erfolgte eine histomorphologische Untersuchung der Zellen des Adipozytenansatzes mithilfe einer histologischen Färbung (Öl-Rot-O). Darüber hinaus wurde die osteogene Differenzierung der Zellen durch den Nachweis eines nicht-kollagenen Proteins der Knochenmatrix (Osteocalcin) mittels eines „enzyme linked immunosorbent assay“ (ELISA) untersucht. Die o.g. Methoden zur Untersuchung des Differenzierungspotentials der Zellreihen sind weitgehend etabliert und müssen daher nicht diskutiert werden.

\subsection{Methodik}

\subsubsection{Messungen und Berechnungen}

Die in dieser Arbeit präsentierten experimentellen Daten der Zellzählung wurden mit Hilfe der JMAK-Formel verifiziert. Diese wurde unabhängig von Johnson, Mehl, Avrami und Kolmogorow zur Beschreibung kristalliner Wachstumskinetiken und Phasentransformationen entwickelt (AVRAMI 1939, AVRAMI 1940, AVRAMI 1941, FANFONI und TOMELLINI 1998). Anhand der Formel $y=\left(1-\exp \left(-k t^{n}\right)\right)$, bei der y der zeitabhängige Anteil der zu untersuchenden Phase ist, $\mathrm{k}$ die Geschwindigkeitskonstante des Wachstumsprozesses und $n$ der Avrami-Exponent, können detaillierte Rückschlüsse auf den vorliegenden Wachstumsprozess gezogen werden. Die Zeitkonstante k definiert die unter den gewählten experimentellen Parametern vorherrschende Geschwindigkeit, in der sich die neue Phase bildet. Der Avrami-Exponent $n$ hingegen modelliert diese 
Geschwindigkeit im Beobachtungszeitraum und passt eine sigmoidale Wachstumsform an. Wenn ein Avrami-Exponent von eins den Wachstumsprozess auf ein exponentielles Wachstum zurückführt, können anhand von Avrami-Exponenten ungleich eins Rückschlüsse auf den Wachstumsprozess gezogen werden. Hierbei gilt, dass die Dimensionalität des Wachstums dim aus dem Avrami-Exponenten hervorgeht: dim = n-1. So gibt es für $\operatorname{dim}=1$ eine Vorzugsrichtung und ein nadelförmiges Wachstum, bei $\operatorname{dim}=2$ zwei Vorzugsrichtungen und eine Plättchenbildung und bei $\operatorname{dim}=3$ sind alle drei Raumrichtungen ähnlich bevorzugt und die neue Phase wächst kugel- bzw. würfelförmig. In der Studie von HILLER (1965) sind einige Dimensionen für $\mathrm{n}$ bei verschiedenen Wachstumsprozessen erklärt. Abbildung 28 zeigt graphisch die Abhängigkeit des Avrami-Exponenten $\mathrm{n}$ auf die sigmoidale Form der Wachstumskurve bei konstanter Wachstumsgeschwindigkeitskonstanten $\mathrm{k}$.

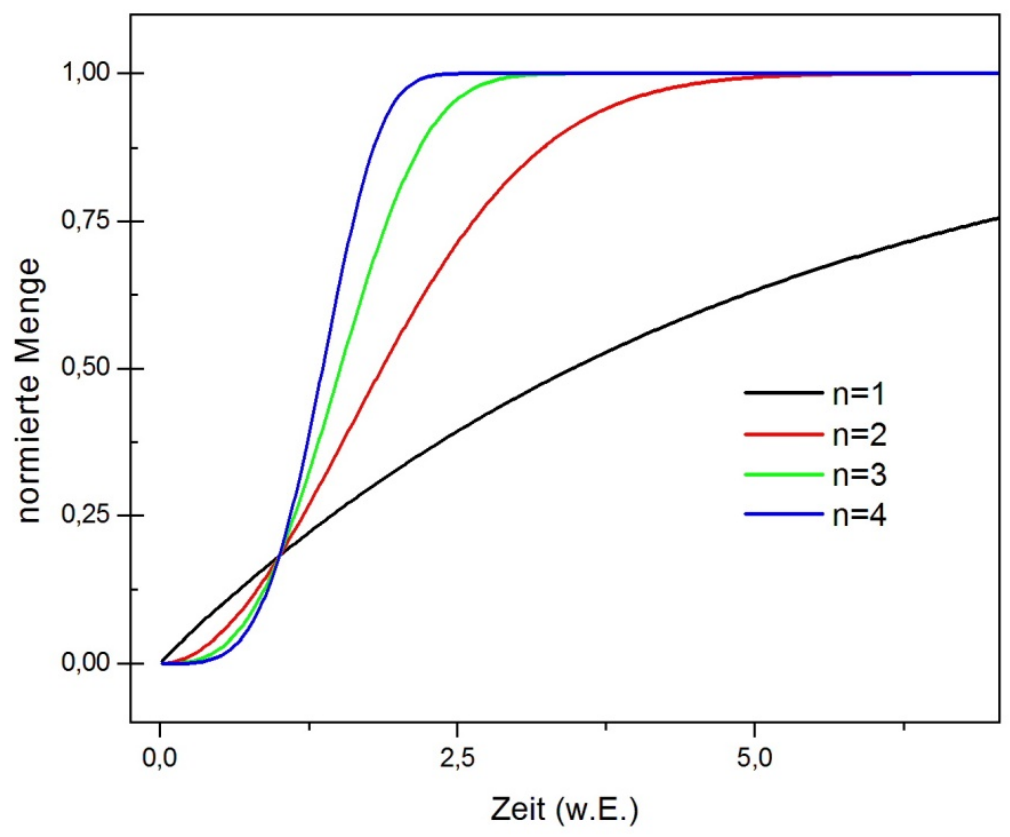

Abb. 28: Einfluss des Avrami-Exponenten $n$ auf die sigmoidale Form der Wachstumskurve bei konstanter Wachstumsgeschwindigkeitskonstante $\mathrm{k}=0,2$ (w.E. = willkürliche Einheit).

Im Rahmen biomedizinischer Anwendungen, die über das Gebiet des einfachen Proteinkristallwachstums hinausgehen, wird das JMAK-Modell sowohl für das Wachstum der Zellen als auch deren Sterblichkeit in verschiedenen Bereichen genutzt (VEKILOV 2010, WILLIAMS et al. 1992, WILLIAMS et al. 1993). Hierzu ist anzumerken, dass es signifikante Unterschiede zwischen Kristallwachstum bzw. Phasentransformationen und dem Zellwachstum durch Teilung gibt, was deutlichen Einfluss auf die Interpreta- 
tion des Avrami-Exponenten hat. Beim Wachstum von Kristallen können Nukleationen beobachtet werden, bei denen eine neue Phase ohne Nachbarn der gleichen Struktur entsteht (ist dies der vorherrschende Prozess, ist der Avrami-Exponent gleich eins und die Dimensionalität gleich null). Dies ist im Bereich der Zellteilung gänzlich ausgeschlossen, da dies faktisch ein Zellwachstum aus Nährlösung ohne Zellteilung bedeuten würde. Da für Zellteilungsprozesse auch keine Vorzugsrichtung (also eine bevorzugte Teilung der Zelle in eine der drei Raumrichtungen) zu erwarten ist, dürften die Avrami-Exponenten gleich bzw. größer vier sein. Die detaillierte Analyse der Dimensionalität bei biomedizinischen Prozessen ist wesentlich komplexer als im Bereich der anorganischen Phasentransformation. Daher werden im Folgenden diese Werte primär zum quantitativen Vergleich der Messungen untereinander genutzt. Abbildung 29 zeigt graphisch den Einfluss der Wachstumsgeschwindigkeitskonstanten k auf den Verlauf der Kurve bei konstantem Avrami-Exponenten $n=4$.

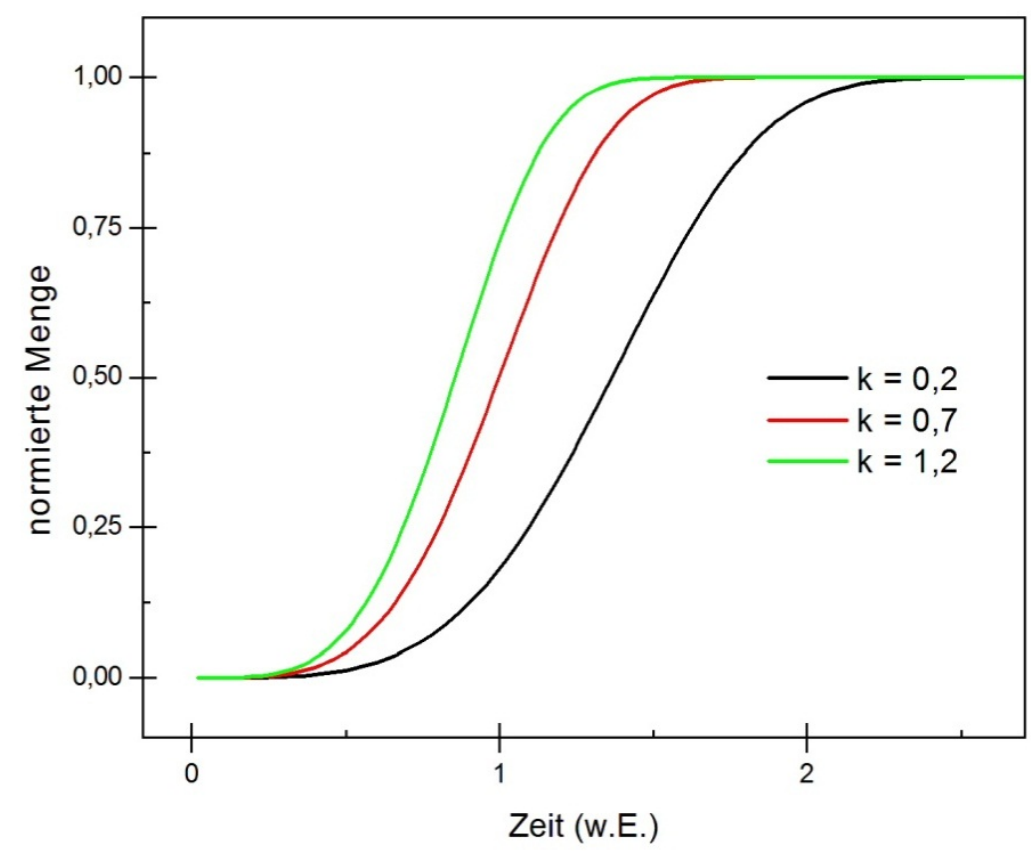

Abb. 29: Einfluss der Wachstumsgeschwindigkeitskonstanten $k$ auf den Verlauf der Kurve bei konstantem Avrami-Exponenten $n=4$ (w.E. = willkürliche Einheit).

\subsubsection{Methodenkritik}

Die vorliegenden Ergebnisse zeigen, dass die Population der Zahnkeimzellen multipotente Stammzellen beinhaltet und diese mithilfe der gewählten Stammzellmarker Stro-1, CD133 und CD271 selektiert werden können. Die gegenwärtigen Versuchsergebnisse unterstreichen somit die Vermutung von SLOAN und WADDINGTON (2008), 
dass innerhalb der Pulpa mehr als eine Stammzellpopulation existiert. Die genannte Forschungsgruppe bezieht ihre Vermutung auf die Zellen der adulten Pulpa, sie scheint aber auch auf Zahnkeimzellen zutreffend zu sein. Im Rahmen dieses Versuches ist evident, dass neben den positiv sortierten Zahnkeimpopulationen, auch die Negativfraktionen der sortierten Zahnkeimzellen über ein osteogenes, chondrogenes und adipogenes Differenzierungspotential verfügen. Dies kann damit begründet sein, dass in den negativ sortierten Zellpopulationen noch weitere Stammzellen vorhanden sind. Beispielsweise enthält die eluierte Mischkultur der Stro-1'-Zellen noch CD133+und CD271 ${ }^{+}$-Zellen, welche dazu in der Lage sind in verschiedene Zelllinien zu differenzieren. Selbiges gilt für die CD133- und CD271-Zellen jeweils bzgl. der zwei anderen Stammzellmarker.

In Bezug auf den vorliegenden Versuchsaufbau wäre es interessant, die Differenzierungs- und Proliferationsunterschiede zwischen einer positiv sortierten Zellfraktion und der dazugehörigen negativen Zellfraktion zu beobachten, welche keinen der drei verwendeten Stammzellmarker aufweist. Um eine solche Negativpopulation zu erhalten, müssten die negativ sortierten Zellen der ersten MAC-Sortierung nochmals mit den beiden verbliebenen Markern sortiert werden. Das Endergebnis wäre dann eine Zellpopulation, die Stro-1/CD133/CD271 ${ }^{-}$ist. Es stellt sich die Frage, ob diese Stro-1 ${ }^{-}$ /CD133\%CD271--Population ebenso dazu in der Lage ist, wie die Stro- $1^{+}-$, CD271+-, CD133+-Zellpopulationen in verschiedene Zelllinien zu differenzieren. Des Weiteren könnte auch eine unsortierte Zellpopulation als Kontrollgruppe parallel zu den positiv und negativ sortierten Zellen untersucht werden. So könnte herausgefunden werden, ob sich die positiv oder negativ sortierten Zellen von der Ausgangspopulation in ihrem Proliferationsverhalten oder Differenzierungspotential unterscheiden. Hinsichtlich des Differenzierungspotentials dentaler Stammzellen konnte bereits nachgewiesen werden, dass DPSCs, SHEDs, SCAPs und HDFCs neben dem adipogenen, chondrogenen und osteogenen Differenzierungspotential, auch über die Fähigkeit verfügen neurogen und myogen zu differenzieren (D'AQUINO et al. 2007, GRONTHOS et al. 2002, LAINO et al. 2005, MIURA et al. 2003, MORSCZECK et al. 2005 a, MORSCZECK et al. 2005 b, SONOYAMA et al. 2008, ZHANG et al. 2006). Die vorliegenden Versuchsergebnisse zeigen, dass das Verhalten der Zahnkeimzellen dem der bisher untersuchten dentalen Stammzellpopulationen ähnelt und die Zahnkeimzellen ebenfalls die Potenz zur adipogenen, osteogenen und chondrogenen Differenzierbarkeit aufweisen. Die vorliegenden Versuchsergebnisse entsprechen somit auch den Beobachtungen von TAKEDA et al. (2008), welche ein osteogenes und adipogenes Differenzierungspotential von Zahnkeimzellen nachweisen konnten. Diese Gruppe konnte des Weiteren anhand der Expression neurogener Marker wie Nestin und $\beta$ III-Tubulin eine neurogene Differenzie- 
rung von Zahnkeimzellen zeigen. Eine myogene Differenzierung von Zahnkeimzellen wurde bisher nicht untersucht und könnte, ebenso wie die Verwendung weiterer Stammzellmarker, Gegenstand künftiger Differenzierungsversuche sein. So konnte beispielsweise die Expression des Stammzellmarkers CD146 bereits bei DPSCs, SCAPs, SHEDs und PDLSCs nachgewiesen werden (CHEN et al. 2006, MIURA et al. 2003, SHI und GRONTHOS 2003, SONOYAMA et al. 2006). Es ist zu vermuten, dass es sich hierbei um einen weiteren wichtigen dentalen Stammzellmarker handelt, der vermutlich ebenso von einer Subpopulation der Zahnkeimzellen exprimiert wird. Dieses bedarf allerdings der weiteren Untersuchung, da in der Literatur diesbezüglich keine Angaben existieren. Da viele der o.g. Versuche mit nicht selektierten Zellpopulationen durchgeführt wurden, wäre es künftig von Interesse, ob beispielsweise das Proliferations- und Differenzierungspotential selektierter Stammzellpopulationen (z.B. Stro- $1^{+} /$ CD133 ${ }^{+}$-Zellen) dem der nicht sortierten Zellpopulationen überlegen ist.

\subsection{Ergebnisse}

\subsubsection{Stammzellmarker}

Einige vorangegangene Studien belegen, dass es sich bei den DPSCs um eine heterogene Zellpopulation handelt. Die Zellen unterscheiden sich in Bezug auf ihre Größe und Morphologie sowie ihres Proliferations- und Differenzierungspotentials (GRONTHOS et al. 2003, KUZNETSOV et al. 1997, STEWARD et al. 2003). Dementsprechend wird nach einer Methode gesucht, mit der die Stammzellpopulationen von den übrigen dentalen Zellen effektiv isoliert werden können. Hierbei finden Stammzellmarker Verwendung, mit deren Hilfe sich bestimmte Subpopulationen selektieren lassen. Stro-1 stellt einen Marker für humane mesenchymale Stammzellen dar und ist einer der am meisten genutzten Antikörper. Stro-1 erkennt ein Oberflächenantigen, das von einer kleinen Anzahl mesenchymaler Stammzellen exprimiert wird. Stro- $1^{+}$-Zellen des Knochenmarkstromas besitzen beispielsweise die Fähigkeit zur Selbsterneuerung und können zu Myozyten, Adipozyten, Osteoblasten und Chondrozyten differenziert werden (DENNIS et al. 2002, GRONTHOS et al. 1994, GRONTHOS et al. 2003, SIMMONS und TOROK-STORB 1991). Humane dentale Pulpazellen (DPSCs) beinhalten ebenfalls Stro- $1^{+}$-Zellen, welche die Potenz zur osteogenen und adipogenen Differenzierung aufweisen. Darüber hinaus konnte die Expression von Stro-1 erfolgreich auf SHEDs, HDFCs und PDLSCs nachgewiesen werden (GRONTHOS et al. 2002, LAINO et al. 2005, MIURA et al. 2003). Die Ergebnisse dieses Versuches belegen, dass Stro- $1^{+}$-Zellen auch in der Population der Zahnkeimzellen zu finden sind. Diese Zellfraktion zeigt ebenfalls ein osteogenes, adipogenes und chondrogenes Differenzierungspotential. Dementsprechend bestätigen die vorliegenden Versuchsergebnisse die 
Aussage, dass der Oberflächenmarker Stro-1 ein wichtiger dentaler Stammzellmarker ist (MORSCZECK et al. 2007).

SHI und GRONTHOS (2003) zeigten, dass die mittels MACS selektierte Stro- $1^{+}$Fraktion ca. $6 \%$ der gesamten Pulpazellen beträgt. Dieses Angabe entspricht in etwa auch dem Anteil der Stro- $1^{+}$-Zellen an der hier untersuchten Zahnkeimzellpopulation (5,84\% bzw. 4,36\%). Darüber hinaus gelang es SHI und GRONTHOS (2003) die Stammzellnische der DPSCs zu lokalisieren. Die DPSC-Stammzellnischen in der humanen dentalen Pulpa befinden sich in den perivaskulären und perineuralen Regionen und konnten mithilfe der Antikörper gegen Stro-1, CD146 und des Perizytenassoziierten-Antigens (3G5) lokalisiert werden. In weiteren Versuchen könnte so beispielsweise untersucht werden, ob die Stammzellpopulation aus dem Zahnkeim ebenfalls über eine perivaskulär und perineural lokalisierte Stammzellnische verfügen.

Der Antikörper $\underline{\mathrm{CD} 271}$, auch als "low affinity nerve growth factor receptor" (LNGFR) bezeichnet, wird in der Literatur als Marker zur Aufreinigung nicht-hämatopoetischer Stammzellen beschrieben. Die Verwendung dieses Antikörpers sollte dazu beitragen, eine homogenere Population multipotenter hMSCs zu erhalten. Im Vergleich zu den Stro- $1^{+}$-Zellen beträgt der Anteil von CD271 $1^{+}$-Zellen an der gesamten Population reifer Pulpazellen weniger als 1\% (SMITH et al. 2005). Diese Angabe konnte in Bezug auf die Zahnkeimzellen nicht bestätigt werden. Den vorliegenden Daten dieses Versuches ist zu entnehmen, dass die CD271+-Zellen in der 2. Passage $10,68 \%$ und in der 4. Passage 2,97\% der Gesamtpopulation ausmachen. Die Population der Zahnkeimzellen scheint dementsprechend zwar mit zunehmender Passageanzahl weniger CD271 ${ }^{+}$-Zellen zu enthalten, verfügt aber im Vergleich zu den reifen Pulpazellen über einen deutlich höheren Anteil an CD271+'-Zellen.

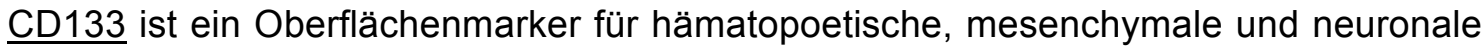
Stammzellen, der erstmalig 1997 entdeckt wurde (D'AQUINO et al. 2007, SHMELKOV et al. 2005, TONDREAU et al. 2005, YIN et al. 1997). Hinsichtlich der Expression von CD133 auf dentalen Pulpastammzellen sind in der Literatur nur unzureichend Daten bekannt. Lediglich D'AQUINO et al. (2007) wiesen das Vorhandensein von CD133Zellen in der reifen Pulpa nach. Es sind allerdings keine Daten bzgl. des prozentualen Anteils von CD133'-Zellen an der Gesamtpopulation bekannt, weswegen ein Vergleich mit den hier untersuchten Zahnkeimzellen nicht möglich ist. Die durchschnittliche relative Zellquantität von $\mathrm{CD}_{133^{+}}$-Zellen an der Zahnkeimpopulation beträgt 8,5\%. In Anbetracht dieser Ergebnisse der vorliegenden Untersuchung scheint die Selektion dentaler Stammzellen aus dem Zahnkeim mit CD133 sehr vielversprechend und sollte weiter untersucht werden. 
In vorangegangenen Studien wurde mehrfach dokumentiert, dass Stro-1 ein wichtiger dentaler Stammzellmarker ist (GRONTHOS et al. 2002, LAINO et al. 2005, MIURA et al. 2003, MORSCZECK et al. 2007). Es stellt sich die Frage, ob die beiden verwendeten Stammzellmarker CD133 und CD271 ebenfalls für die Selektion dentaler Stammzellen geeignet sind, da in der Literatur zu diesen zwei Stammzellmarkern bisher nur unzureichende Angaben vorliegen. Die Proliferationsergebnisse zeigen, dass die CD $133^{+}$- und CD271 ${ }^{+}$-Zellen sowohl im adipogenen als auch osteogenen Differenzierungsmedium besser und schneller proliferieren als die Stro- $1^{+}-$Zellen. In Bezug auf das Differenzierungspotential der CD $133^{+}$- und $\mathrm{CD} 271^{+}$-Zellen wird deutlich, dass die CD $133^{+}$-Zellen ebenso wie die Stro- $1^{+}$-Zellen die Potenz zur adipogenen, chondrogenen und osteogenen Differenzierung aufweisen. Daher lässt sich anhand der gegenwärtigen Versuchsergebnisse vermuten, dass CD133 ebenfalls einen potenten Stammzellmarker für die Selektion dentaler Stammzellen darstellt, zumal das Proliferationsverhalten der CD133+-Zellen dem der Stro- $1^{+}$-Zellen überlegen zu sein scheint.

Die positiv sortierten CD271-Zellen weisen hingegen nicht das gleiche Differenzierungspotential wie die CD133+- und die Stro- $1^{+}$-Zellen auf. Es konnte zum Beispiel keine chondrogene Differenzierung der CD $271^{+}$-Zellen beobachtet werden. Zwar gelang es, die CD271 ${ }^{+}$-Zellen in adipogene Richtung zu differenzieren, bzgl. der osteogenen Differenzierung waren aber Unterschiede zwischen verschiedenen Zahnkeimpopulationen evident, so dass eine osteogene Differenzierung nur teilweise nachweisbar war. Zusammenfassend lässt sich feststellen, dass die CD271 $1^{+}$-Zellen den Stro- $1^{+}$-Zellen bzgl. des Proliferationsverhaltens zwar überlegen sind, aber nicht die gleiche Multipotenz aufweisen. Dementsprechend scheint sich CD271, den vorliegenden Versuchsergebnissen zufolge, nicht als Marker für die Hartgewebebildung dentaler Stammzellen aus dem Zahnkeim zu eignen.

\subsubsection{Proliferation}

Die Zahnkeimzellen zeigen ebenso wie die DPSCs eine fibroblastenähnliche Morphologie und weisen ein adhäsives Wachstum auf. Sie bilden nach 5-tägiger Kultivierung Kolonien. Dieses Verhalten entspricht dem in der Literatur beschriebenen Proliferationsverhalten von DPSCs und den von TAKEDA et al. (2008) beobachteten Wachstum von Zahnkeimzellen (GRONTHOS et al. 2000, GRONTHOS et al. 2002). Dieses Wachstumsverhalten war sowohl im Rahmen des adipogenen als auch osteogenen Assays evident. Hinsichtlich des Proliferationsverhaltens der Zahnkeimzellen des chondrogenen Assays sind keine Angaben möglich, da die Zellen aufgrund des Versuchsaufbaus nicht mikroskopisch untersucht und keine Zellzählung durchgeführt werden konnten. 
Die vorliegenden Versuchsergebnisse zeigen, dass die untersuchten Zellpopulationen des osteogenen Assays nach einer inaktiven Phase von ca. fünf Tagen verstärkt mit der Proliferation beginnen. Diese Beobachtung entspricht in etwa dem von D'AQUINO et al. (2007) festgestellten Proliferationsverhalten der DPSCs, welche nach sechs Tagen eine signifikante Zunahme ihrer Proliferation zeigen. Im Vergleich der positiv sortierten Zellpopulationen dieses Versuches erreichen die CD271+-Zellen im osteogenen Assay die höchste Zellzahl sowie maximale Wachstumsgeschwindigkeit. Die CD $133^{+}$-Zellen proliferieren ähnlich stark wie die CD $271^{+}$-Zellen. Die Stro- $1^{+}$-Zellen weisen hingegen sowohl die geringste Zellzahl, Wachstumsgeschwindigkeitskonstante als auch die niedrigste maximale Wachstumsgeschwindigkeit auf.

Anhand der Proliferationsdaten des adipogenen Assays wird deutlich, dass auch hier die Stro- $1^{+}$-Zellen den $C D 133^{+}$- und $C D 271^{+}$-Zellen in ihrem Proliferationsverhalten unterlegen sind. Alle Zellpopulationen des adipogenen Assays beginnen erst ab dem 10. Tag verstärkt mit der Proliferation und somit ca. fünf Tage später als die Zellen des osteogenen Assays. Insgesamt zeigen die Proliferationsergebnisse, dass die selektierten Zahnkeimpopulationen unter den gegebenen Versuchsbedingungen im osteogenen Differenzierungsmedium besser und schneller proliferieren als im adipogenen Differenzierungsmedium. Ein möglicher Grund für das beobachtete Proliferationsverhalten der Zellen könnte die Verwendung der unterschiedlichen Differenzierungsmedien sein.

Ein weiterer Parameter, der Einfluss auf das Proliferationsverhalten der selektierten Zahnkeimzellen haben könnte, ist die Zelldichte. Im Rahmen des osteogenen Assays wurden zu Versuchsbeginn jeweils 50.000 Zellen/Well in 6-Well-Platten ausgesät, während im adipogenen Assay 50.000Zellen/Well in 12-Well-Platten ausplattiert wurden. Anhand der gegenwärtigen Versuchsergebnisse könnte man vermuten, dass die Zahnkeimzellen mit einer geringeren Zelldichte in 6-Well-Platten besser proliferieren als in 12-Well-Platten. Zur Verifizierung dieser Vermutung müssten jedoch weitere Versuche unter vergleichbaren Versuchsbedingungen durchgeführt werden, indem die Aussaat gleicher Ausgangszellzahlen/Well sowohl im adipogenen als auch im osteogenen Differenzierungsmedium jeweils in 6- bzw. 12-Well-Platten erfolgt. So könnte näher untersucht werden, ob die Zelldichte oder das Differenzierungsmedium für das unterschiedliche Proliferationspotential der Zellen verantwortlich ist.

\subsubsection{Differenzierung}

GRONTHOS et al. (2000) gelang erstmalig die Identifizierung und Isolierung dentaler Stammzellen aus der adulten Pulpa. Die Identifizierung der dentalen Pulpastammzellen (DPSCs) erfolgte anhand ihrer klonogenen Fähigkeiten, der schnellen Prolifera- 
tionsrate sowie der Fähigkeit in vivo und in vitro mineralisiertes Gewebe zu bilden. Des Weiteren konnte gezeigt werden, dass die DPSCs in der Lage sind, in verschiedene Zelltypen zu differenzieren (GRONTHOS et al. 2002). Es stellt sich die Frage, ob auch die Population der Zahnkeimzellen ein ähnliches Differenzierungspotential aufweist. TAKEDA et al. (2008) charakterisierten bisher als erste Gruppe das Proliferations- und Differenzierungspotential von dentalen Pulpazellen, welche aus einem Zahnkeim mit nicht abgeschlossenem Wurzelwachstum gewonnen werden konnten.

\subsubsection{Osteogene Differenzierung}

Der Nachweis einer osteogenen Differenzierung der Zahnkeimzellen erfolgte mittels OCN-ELISA, RTq-PCR und PCR anhand der Expression osteogener Differenzierungsmarker (Osteocalcin, Osteopontin, Osteocrin, Osteonectin, Col1A1, Cbfa1). Osteocalcin ist ein nicht-kollagenes Protein der Knochenmatrix und stellt einen spezifischen Marker für das späte Differenzierungsstadium von Osteoblasten dar (AUBIN und LIU 1996, RICKARD et al. 1996). Osteocalcin wird von den reifen Osteoblasten sezerniert und ist mit einem Anteil von 1-2\% das in höchster Konzentration vorkommende nicht-kollagene Protein des Knochens. Bei dentalen Zellen aus dem Pulpagewebe (DPSCs), sowie den SHEDs, SCAPs und HDFCs konnte die Expression von Osteocalcin bereits nachgewiesen werden (D'AQUINO et al. 2007, GRONTHOS et al. 2000, MIURA et al. 2003, MORSCZECK 2005 a, MORSCZECK 2005 b, SONOYAMA et al. 2008). Die Regulation der Osteocalcinexpression erfolgt über den Transkriptionsfaktor "Core binding factor 1“ (Cbfa1), welcher einen essentiellen Transkriptionsfaktor der Osteoblastendifferenzierung darstellt. Unter anderem reguliert er neben der Osteocalcinexpression die Expression weiterer osteogener Marker wie Osteopontin und Col1A1 (AUBIN et al. 2002, DUCY und KARTENSY 1998). Osteopontin wird von Präosteoblasten und Osteoblasten in der Phase der extrazellulären Matrixentwicklung und Matrixreifung gebildet (MALAVAL et al. 1994, RICKARD et al. 1996). Osteonectin ist ebenso wie Osteopontin ein nicht-kollagener Bestandteil der Knochenmatrix und wird von Osteoblasten exprimiert.

Die PCR zeigt eine osteogene Differenzierung aller positiv und negativ sortierten Zellpopulationen. Das Expressionsmuster von Osteocalcin, Osteopontin, Osteonectin, Col1A1 und Cbfa1 entspricht in allen Zellpopulationen dem in der Literatur beschriebenen Bild der Osteoblastendifferenzierung. In vorangegangenen Studien konnte bereits gezeigt werden, dass die DPSCs neben Osteocalcin auch Col1A1, Osteonectin und Osteopontin exprimieren (SHI et al. 2005). Den vorliegenden Ergebnissen ist zu entnehmen, dass die untersuchten Zahnkeimzellen ebenfalls die genannten Marker 
exprimieren und somit ebenso wie die DPSCs über ein osteogenes Differenzierungspotential verfügen.

Darüber hinaus konnte eine osteogene Differenzierung der Stro- $1^{+/}$-Zellen und der CD $133^{+/}$-Zellen anhand des OCN-ELISAs und der RTq-PCR beobachtet werden. Sowohl die Stro- $1^{+/}$-Zellen als auch die CD133 ${ }^{+/}$-Zellen weisen eine Sekretion bzw. Expression von Osteocalcin auf. Hingegen zeigen die CD $271^{+/}$-Zellen keine oder nur eine geringfügige Expression von Osteocalcin im Rahmen des OCN-ELISAs und der RTq-PCR.

Eine mögliche Erklärung für die abweichende OCN-Expression der CD271 ${ }^{+/}$-Zellen bei dem ELISA und der RTq-PCR könnte die Verwendung von Zellpopulationen aus verschiedenen Zahnkeimen sein. Die Werte des OCN-ELISAs und der RTq-PCR sind aus derselben Zellpopulation eines Zahnkeims gewonnen und weisen übereinstimmende Ergebnisse auf. Die Zellen, welche im Anschluss an einen osteogenen Assay mittels PCR untersucht wurden, stammen aus einem anderen Zahnkeim. Die vorliegenden Ergebnisse lassen vermuten, dass es sich bei den Zellen der Zahnkeime um eine heterogene Population handelt, die von Individuum zu Individuum variieren kann. Die unterschiedlichen Entwicklungsstadien der Zahnkeime könnten für den Differenziertheitsgrad der Zahnkeimzellen und der entsprechenden Expression verschiedener Oberflächenmarker ebenfalls von Bedeutung sein.

So konnte in vorangegangenen Studien bereits nachgewiesen werden, dass Pulpazellen aus Zahnkeimen mit abgeschlossenem Kronenwachstum stärker proliferieren als Zellen aus fortgeschritteneren Entwicklungsstadien. Darüber hinaus konnte gezeigt werden, dass die Wachstumsrate sowie die Potenz zur Differenzierung der Zellen mit zunehmender Passagezahl abnimmt (TAKEDA et al. 2008).

Das Differenzierungspotential der verschiedenen Zellpopulationen (Stro- $1^{+/-}, \mathrm{CD} 271^{+/}$, $\mathrm{CD}_{133^{+/}}$) in Bezug auf den OCN-ELISA zeigt, mit Ausnahme der CD271 ${ }^{+/}$-Zellen, dass sowohl die positiven als auch die negativen Zellpopulationen OCN sezernieren. Bei den Stro- $1^{+}$- und Stro- $1^{-}$-Zellen ist bzgl. der OCN-Konzentration kein deutlicher Unterschied zwischen beiden Populationen evident, während die CD133-Zellen eine deutlich höhere OCN-Konzentration aufweisen als die CD133 ${ }^{+}$-Zellen. Ursache für die OCN-Sekretion und damit Hinweis auf eine osteogene Differenzierung der negativ sortierten Zellen könnte das Vorhandensein weiterer Stammzellen in der jeweiligen Negativfraktion sein. Zwar wurde im Rahmen der MAC-Sortierung jeweils eine Stammzellpopulation mithilfe des jeweilig verwendeten Stammzellmarkers (Stro-1, CD133, CD271) aus der Mischpopulation extrahiert, die eluierte Negativfraktion könnte aber noch andere Stammzellpopulationen beinhalten. Dies könnte erklären, warum sowohl 
bei der PCR, RTq-PCR und bei dem ELISA sowohl die negativen als auch die positiven Zellen über ein osteogenes Differenzierungspotential verfügen. Die Potenz zur Differenzierung der sowohl positiven als auch der negativen Zahnkeimpopulationen ist auch in den adipogenen und chondrogenen Assays evident.

\subsubsection{Chondrogene Differenzierung}

Bereits durchgeführte Studien beweisen, dass die DPSCs, SHEDs und PDLSCs dazu in der Lage sind chondrogen zu differenzieren (GAY et al. 2007, KERKIS et al. 2006, ZHANG et al. 2006). Die Ergebnisse dieses chondrogenen Assays zeigen, dass mit Ausnahme der CD271+-Zellen die untersuchten Zahnkeimzellen chondrogenes Differenzierungspotential aufweisen. Untersucht wurde die Expression von Aggrecan, Sox9 und Chondroadherin. Aggrecan wird während der Chondrogenese von den Knorpelzellen synthetisiert und ist Bestandteil der Extrazellularmatrix (LEFEBVRE und SMITS 2005). Sox9 ist auf regulatorischer Ebene für die Expression der Gene für Kollagen Typ II, XI und Aggrecan verantwortlich (BRIDGEWATER et al. 1998, LEFEBVRE und SMITS 2005, LIU et al. 2000, SEKIYA et al. 2000). Chondroadherin ist ein Proteoglycan, welches einen Hauptbestandteil der extrazellulären Knochenmatrix darstellt (MÅNSSON et al. 2001). Auch im Rahmen dieses Versuches lassen sich keine deutlichen Unterschiede bzgl. des Differenzierungspotentials zwischen den positiv und negativ sortierten Stro-1- bzw. CD133-Zellen feststellen. Die Ergebnisse des chondrogenen Assays lassen vermuten, dass der Stammzellmarker CD271 eine Zellpopulation markiert, welche nicht zur chondrogenen Differenzierung in der Lage ist.

\subsubsection{Adipogene Differenzierung}

In vorangegangenen Studien konnte gezeigt werden, dass DPSCs nach 5-wöchiger Differenzierung in Adipozytendifferenzierungsmedium adipogen differenzieren können. Molekularbiologisch war eine Hochregulation des Transkriptionsfaktors PPAR $\gamma$ festzustellen sowie histologisch eine positive Öl-Rot-O-Färbung der Zellen (GRONTHOS et al. 2002). Die PDLSCs und die HDFSCs wiesen sogar bereits nach 25 bzw. 21 Tagen die Fähigkeiten zur adipogenen Differenzierung auf (GAY et al. 2007, KEMOUN et al. 2007). Hinsichtlich der adipogenen Differenzierung von Zahnkeimzellen konnten TAKEDA et al. (2008) nach 28 Tagen histologisch lipidhaltige Fettzellen nachweisen, es war jedoch keine Expression von PPAR $\gamma$ evident. Der Transkriptionsfaktor PPAR $\gamma$ kommt fast ausschließlich im Fettgewebe vor und gilt als Hauptregulator der Adipogenese (TONTONOZ et al. 1994 a, TONTONOZ et al. 1994 b). FABP4 ist ein Schlüsselmediator für den intrazellulären Transport und den Metabolismus von Fettsäuren im Fettgewebe. FABP4 wird von Adipozyten exprimiert, bindet Fettsäuren mit hoher Affinität und transportiert diese in verschiedene Bereiche der Zelle. In Verbindung mit Fett- 
säuren interagiert und moduliert FABP4 die Aktivität von PPAR $\gamma$ (GORBENKO et al. 2006).

Die untersuchten Zahnkeimpopulationen zeigen alle grundsätzlich eine Expression von PPAR $\gamma$ und damit eine generelle Potenz für eine adipogene Differenzierbarkeit. Es zeigen sich keine auffälligen Expressionsunterschiede zwischen den positiv und negativ sortierten Zellen bzgl. PPAR $\gamma$. Dieses Ergebnis konnte durch eine weitere molekularbiologische Untersuchung mit FABP4 nur teilweise bestätigt werden, da FABP4 nur vereinzelt von einigen Zellpopulationen exprimiert wurde. Histologisch ist bei allen Zellpopulationen nach 28-tägiger Differenzierung, mit Ausnahme der Stro- $1^{+}$-Zellen, nur eine geringfügige Bildung von Lipidvakuolen evident. Es konnten zu keinem Zeitpunkt bei einer der sortierten Zellpopulationen reife Adipozyten beobachtet werden. Diese Ergebnisse zeigen, dass sowohl die positiven als auch die negativen Zellpopulationen der verwendeten Stammzellmarker die Fähigkeit besitzen, adipogen zu differenzieren. Es ist aber zu vermuten, dass sich die untersuchten Zellen noch in einem Frühstadium der adipogenen Differenzierung befanden. In künftigen Untersuchungen sollte durch eine längere Versuchsdauer festgestellt werden, ob die Zahnkeimzellen ebenso wie die DPSCs nach 5-wöchiger Differenzierung reife Adipozyten aufweisen, oder ob sich die Zahnkeimzellen von den DPSCs in ihrem adipogenen Differenzierungsverhalten unterscheiden. Der Adipozyten-spezifische Marker Lipoprotein-Lipase (LPL) konnte bei der Differenzierung von DPSCs bereits mehrfach nachgewiesen werden und könnte dementsprechend bei Versuchen mit Zahnkeimzellen als weiterer Marker zur Überprüfung einer adipogenen Differenzierung angewendet werden (GRONTHOS et al. 2002, JO et al. 2007).

Eine mögliche Erklärung für die Expression der osteogenen (Osteopontin, Col1A1, Cbfa1) und des chondrogenen Differenzierungsmarkers (Chondroadherin) im adipogenem Differenzierungsmedium könnte das Vorliegen einer heterogenen Mischpopulation der Zahnkeimzellen sein. So könnten in der Negativfraktion der CD271-Zellen beispielsweise noch Stro- $1^{+}$-Zellen oder CD $133^{+}$-Zellen vorhanden sein. Darüber hinaus können sich die Zellen zu den Erntezeitpunkten in verschiedenen Stadien der Differenzierung befunden haben, was zu unterschiedlichen Expressionsmustern geführt haben könnte. Einige der Zellen waren eventuell bereits für eine osteogene bzw. chondrogene Differenzierung determiniert, wodurch sich die Expression der osteogenen und chondrogenen Differenzierungsmarker im Rahmen des adipogenen Assays erklären ließe. Insgesamt kann aus den Ergebnissen gefolgert werden, dass die Population der Zahnkeimzellen multipotente Stammzellen beinhaltet, welche ein chondrogenes, adipogenes und osteogenes Differenzierungspotential aufweisen. 


\section{Zusammenfassung}

Ziel dieser Studie war die Untersuchung und Charakterisierung humaner dentaler Zahnkeimzellen bzgl. ihres Proliferations- und Differenzierungspotentials, sowie die Klärung der Fragestellung, ob die Population der Zahnkeimzellen multipotente Stammzellen beinhaltet. Die Zahnkeimzellen wurden mithilfe der Stammzellmarker Stro-1, CD133 und CD271 selektiert, kultiviert und bzgl. ihres Proliferationsverhaltens und ihres adipogenen, osteogenen und chondrogenen Differenzierungspotentials untersucht.

Die gegenwärtigen Versuchsergebnisse zeigen, dass die untersuchten Zahnkeimzellen die Stammzellmarker Stro-1 (ca. 5\%), CD271 (ca. 6,8\%) und CD133 (ca. 8,5\%) exprimieren. Der Anteil der Stro- $1^{+}$-Zellen an der Gesamtpopulation der Zahnkeimzellen ist am geringsten, während der Oberflächenmarker CD133 von den Zahnkeimzellen am stärksten exprimiert wird. Im Vergleich der positiv sortierten Zellpopulationen wird deutlich, dass die Stro- $1^{+}$-Zellen den CD133+-Zellen und den CD271 ${ }^{+}$-Zellen hinsichtlich ihres Proliferationsverhaltens sowohl im adipogenen als auch im osteogenen Differenzierungsmedium unterlegen sind. Mit maximalen Zellzahlen von 430.131 Zellen im osteogenen bzw. 149.199 Zellen im adipogenen Differenzierungsmedium erreichten die Stro- $1^{+}$-Zellen die geringste Zellzahl der drei sortierten positiven Zellpopulationen bei Aussaat gleicher Ausgangszellzahlen von 50.000 Zellen/Well. Des Weiteren zeigten die Stro- $1^{+}$-Zellen in beiden Differenzierungsmedien die geringsten Wachstumsgeschwindigkeiten. Im Rahmen des osteogenen Differenzierungsassays konnte eine maximale Wachstumsgeschwindigkeit der Stro- $1^{+}$-Zellen von 80.361 Zellen/Tag beobachtet werden, während die Stro- $1^{+}$-Zellen in dem adipogenen Differenzierungsmedium mit einer maximalen Zellzahl von 11.096 Zellen/Tag proliferierten. Neben den geringen Wachstumsgeschwindigkeiten und den niedrigen Zellzahlen erreichten die Stro- $1^{+}$-Zellen den Zeitpunkt der maximalen Wachstumsgeschwindigkeit im adipogenen Differenzierungsmedium erst an Tag 21 und somit deutlich später als die CD133 ${ }^{+}$Zellen (Tag 16) und die CD $271^{+}$-Zellen (Tag 14). Im osteogenen Differenzierungsmedium waren keine deutlichen Unterschiede bzgl. des Erreichens der maximalen Wachstumsgeschwindigkeiten zwischen den CD133 ${ }^{+}$(Tag 7,8), CD271 ${ }^{+}-(\operatorname{Tag} 6,1)$ und den Stro- $1^{+}$-Zellen (Tag 7,5) evident. Hinsichtlich des Differenzierungspotentials der Stro- $1^{+}$-Zellen zeigen die Ergebnisse, dass die selektierten Zellen über die Kapazität zur osteogenen, adipogenen und chondrogenen Differenzierung verfügen. Die Stro- $1^{+}$-Zellen exprimierten die osteogenen (Osteocalcin, Osteopontin, Osteocrin, Osteonectin, Col1A1, Cbfa1), chondrogenen (Chondroadherin, Aggrecan, Sox9) und 
adipogenen (PPAR $\gamma$, FABP4) Differenzierungsmarker. Darüber hinaus war eine OCNSekretion $(10 \mathrm{ng} / \mathrm{ml})$ anhand des durchgeführten OCN-ELISAs evident, ebenso wie eine deutliche OCN-Expression (280\%) an Tag 16 der Differenzierung bei der RTqPCR.

Die CD133+-Zellen wiesen im osteogenen und im adipogenen Differenzierungsmedium maximale Zellzahlen von 761.359 Zellen bzw. 325.624 Zellen auf. Die maximale Wachstumsgeschwindigkeit von 211.765 Zellen/Tag erreichten sie im Rahmen des osteogenen Assays an Tag 7,8. Im adipogenen Differenzierungsmedium betrug die maximale Wachstumsgeschwindigkeit 42.519 Zellen/Tag und wurde von den CD133+Zellen an Tag 16,6 erreicht. Die CD133 ${ }^{+}$-Zellen proliferierten diesen Ergebnissen entsprechend sowohl im adipogenen als auch im osteogenen Differenzierungsmedium besser als die Stro- $1^{+}$-Zellen. Hinsichtlich der Differenzierbarkeit der CD133 ${ }^{+}$-Zellen konnte die Kapazität zur osteogenen, chondrogenen und adipogenen Differenzierung beobachtet werden. Im Rahmen des OCN-ELISAs der CD $133^{+}$-Zellen war eine OCNSekretion von 7,5 ng/ml evident. Die RTq-PCR zeigte eine OCN-Expression von $140 \%$ an Tag 16 der Differenzierung. Die CD133'-Zellen exprimierten alle o.g. adipogenen, chondrogenen und osteogenen Differenzierungsmarker (PCR). Diese Ergebnisse zeigen, dass die CD133+-Zellen über ein multipotentes Differenzierungspotential verfügen, den Stro- $1^{+}$-Zellen in ihrer OCN-Sekretion (ELISA) und OCN-Expression (RTq-PCR) jedoch unterlegen sind.

Im Vergleich zu den Stro- $1^{+}$-und $\mathrm{CD} 133^{+}$-Zellen wiesen die CD271+-Zellen im osteogenen Differenzierungsmedium ein überlegenes Proliferationsverhalten auf. Mit einer maximalen Zellzahl von 1.347.641 und dem Erreichen der maximalen Wachstumsgeschwindigkeit von 484.550 Zellen/Tag an Tag 6,1 proliferierten die CD271 ${ }^{+}$-Zellen im osteogenen Medium am stärksten. Im Rahmen des adipogenen Assays erreichten die CD271 $1^{+}$-Zellen eine maximale Zellzahl von 244.636 Zellen und an Tag 14 eine Wachstumsgeschwindigkeit von 36.627 Zellen/Tag. Diesen Ergebnissen zufolge proliferierten die CD271+-Zellen im adipogenen Medium geringfügig schlechter als die CD133Zellen, jedoch immer noch deutlich stärker als die Stro- $1^{+}$-Zellen. In Bezug auf ihr Differenzierungspotential zeigten sich die $\mathrm{CD} 271^{+}$-Zellen den Stro- $1^{+}$-Zellen und den CD133+-Zellen unterlegen. Die CD271 ${ }^{+}$-Zellen exprimierten die o.g. osteogenen und den adipogenen Differenzierungsmarker PPAR $(P C R)$. Die Auswertungen des OCNELISAs und der RTq-PCR zeigten jedoch nur eine sehr geringfügige OCN-Sekretion (2,5 ng/ml, welche der OCN-Konzentration des osteogenen Mediums entspricht), bzw. eine OCN-Expressison von 10\% an Tag 16 der Differenzierung. Des Weiteren konnte keine chondrogene Differenzierbarkeit der CD271 ${ }^{+}$-Zellen beobachtet werden. 
Darüber hinaus zeigen die Proliferationsergebnisse der selektierten Zellpopulationen, dass die Zahnkeimzellen im osteogenen Differenzierungsmedium besser proliferierten als im adipogenen Differenzierungsmedium. Die selektierten Zellpopulationen erreichten im osteogenen Differenzierungsmedium durchschnittlich eine höhere Zellzahl (MW = 846.377 Zellen) und eine höhere Wachstumsgeschwindigkeit (MW = 258.892 Zellen/Tag), welche sie früher (MW = Tag 7,1) als im adipogenen Differenzierungsmedium erreichten. Im adipogenen Medium wiesen die Zellen im Durchschnitt eine maximale Zellzahl von 239.812 Zellen und eine maximale Wachstumsgeschwindigkeit von 30.080 Zellen/Tag auf, welche durchschnittlich an Tag 17,4 erreicht wurde.

Zusammenfassend lässt sich sagen, dass die CD271 ${ }^{+}$-Zellen und CD133 ${ }^{+}$-Zellen den Stro- $1^{+}$-Zellen, hinsichtlich des Proliferationspotentials, eine Überlegenheit aufweisen. Diese Beobachtung ist jedoch nicht auf die Differenzierungskapazität der selektierten Zellpopulationen zutreffend. Die Versuchsergebnisse zeigen, dass sowohl die Stro- $1^{+}$-Zellen als auch die CD133 ${ }^{+}$-Zellen chondrogen, adipogen und osteogen differenzieren können und diese Stammzellmarker dementsprechend gut für die Selektion von Zahnkeimstammzellen geeignet sind. Die CD271 ${ }^{+}$-Zellen zeigen hingegen Defizite bzgl. ihres chondrogenen und osteogenen Differenzierungspotentials. Insgesamt ist festzustellen, dass die Population der Zahnkeimzellen adulte multipotente Stammzellen beinhaltet, was durch die erfolgreiche Selektion von Stammzellen mithilfe der genannten Stammzellmarker (Stro-1, CD133, CD271) sowie der anschließenden osteogenen, chondrogenen und adipogenen Differenzierung bewiesen werden konnte. Die Beobachtung, dass sowohl die positiv als auch die negativ sortierten Zellen dazu in der Lage sind in verschiedene Zelllinien zu differenzieren, lässt vermuten, dass die eluierten Populationen an Zahnkeimzellen weitere Stammzelltypen beinhalten. Neben den positiv sortierten Zellen $\left(\right.$ Stro- $1^{+}, \mathrm{CD} 133^{+}, \mathrm{CD} 271^{+}$) wiesen auch die Stro- $1^{-}$, CD133- und CD271-Zellen die Fähigkeit zur osteogenen, chondrogenen und adipogenen Differenzierbarkeit auf. Dieses lässt darauf schließen, dass in den verbliebenen Mischkulturen die Stro- $1^{+}$-Zellen die CD133+-Zellen ersetzen können und umgekehrt.

Die molekularbiologischen Auswertungen in Verbindung mit den histologischen und zellbiologischen Ergebnissen dieses Versuches demonstrieren, dass innerhalb eines Zahnkeims unterschiedliche Stammzellpopulationen existieren, welche es künftig weiter zu untersuchen gilt. Die extrahierten Zahnkeime erwiesen sich als geeignetes Gewebematerial zur Gewinnung humaner adulter Stammzellen unter In-vitroBedingungen. In weiterführenden Versuchen könnte die Charakterisierung weiterer Stammzellmarker von Interesse sein. 


\section{Anhang}

Tab. 9: Zellkulturreagenzien und Zellkulturzubehör

\begin{tabular}{|c|c|c|}
\hline Zellkulturreagenzien & Hersteller & Ordernummer \\
\hline $\begin{array}{l}\text { DMEM (Dulbecco's Modified Eagle } \\
\text { Medium) }\end{array}$ & Gibco Invitrogen, Karlsruhe & $21885-025$ \\
\hline Fetales Kälberserum (FKS) & Biochrom AG, Berlin & S0115 \\
\hline Penicillin Streptomycin Lösung & Biochrom AG, Berlin & A2212 \\
\hline MACS-Puffer & Eigene Herstellung (siehe Anhang) & \\
\hline PBS (without $\mathrm{Ca} / \mathrm{Mg}$ ) & PAN Biotech GmbH, Aidenbach & P0436500 \\
\hline Trypsin $(0,025 \%)$ & PAN Biotech GmbH, Aidenbach & P10-019500 \\
\hline NH Expansion Medium & $\begin{array}{l}\text { Miltenyi Biotec, Miltenyi Biotec } \mathrm{GmbH} \text {, Bergisch } \\
\text { Gladbach }\end{array}$ & $130-091-680$ \\
\hline NH AdipoDiff Medium & $\begin{array}{l}\text { Miltenyi Biotec, Miltenyi Biotec } \mathrm{GmbH} \text {, Bergisch } \\
\text { Gladbach }\end{array}$ & $130-091-680$ \\
\hline NH OsteoDiff Medium & $\begin{array}{l}\text { Miltenyi Biotec, Miltenyi Biotec } \mathrm{GmbH} \text {, Bergisch } \\
\text { Gladbach }\end{array}$ & $130-091-678$ \\
\hline $\begin{array}{l}\text { hMSC chondrogenesis induction medi- } \\
\text { um }\end{array}$ & Provitro, Berlin & 2130902 \\
\hline Petrischalen, $58 \mathrm{~cm}^{2}$ & Sarstedt, Sarstedt AG \& CO, Nümbrecht & 831801 \\
\hline Zellkulturflasche, $75 \mathrm{~cm}^{2}$ & Greiner, Bio-One GmbH, Solingen & 658175 \\
\hline Eppendorf-Röhrchen 1-2 ml & Eppendorf, Wesseling-Berzdorf & 0030120.973 \\
\hline CryoTubes, $1,8 \mathrm{ml}$ & Nunc, Roskilde, Denmark & 377267 \\
\hline 6-Well-Platten & Greiner, Bio-One GmbH, Solingen & 657160 \\
\hline 24-Well-Platten, HTS & Corning B.V. Life Science, Netherlands & 3413 \\
\hline 12-Well-Platten Cellstar & Greiner, Bio-One $\mathrm{GmbH}$, Solingen & 665180 \\
\hline $\begin{array}{l}\text { Transwell-Einsatz, Gase: } 4 \mu \mathrm{m}, \mathrm{d}: 6,5 \\
\mathrm{~mm}\end{array}$ & Corning B.V. Life Science, Netherlands & 3413 \\
\hline MS Columns & $\begin{array}{l}\text { Miltenyi Biotec, Miltenyi Biotec } \mathrm{GmbH} \text {, Bergisch } \\
\text { Gladbach }\end{array}$ & $130-042-201$ \\
\hline MiniMACS Separation Unit & $\begin{array}{l}\text { Miltenyi Biotec, Miltenyi Biotec } \mathrm{GmbH} \text {, Bergisch } \\
\text { Gladbach }\end{array}$ & $130-042-102$ \\
\hline
\end{tabular}


Tab. 10: Nachweismaterialien und Gebrauchslösungen

\begin{tabular}{|c|c|c|}
\hline Produkt & Hersteller & Ordernummer \\
\hline N-MID® Osteocalcin ELISA Kit & $\begin{array}{l}\text { nordic bioscience, Immunodiagnostic Systems } \\
\text { Limited, Boldon, UK }\end{array}$ & $30 S c 4000$ \\
\hline $\begin{array}{l}\text { Stro-1 Goat-Anti-Mouse IgG Mi- } \\
\text { croBeads }\end{array}$ & $\begin{array}{l}\text { Miltenyi Biotec, Miltenyi Biotec } \mathrm{GmbH} \text {, Bergisch } \\
\text { Gladbach }\end{array}$ & $130-048-401$ \\
\hline CD133 MicroBead Kit human & $\begin{array}{l}\text { Miltenyi Biotec, Miltenyi Biotec } \mathrm{GmbH} \text {, Bergisch } \\
\text { Gladbach }\end{array}$ & $130-050-801$ \\
\hline CD271 MicroBead Kit (PE) human & $\begin{array}{l}\text { Miltenyi Biotec, Miltenyi Biotec GmbH, Bergisch } \\
\text { Gladbach }\end{array}$ & $130-092-819$ \\
\hline 2-Propanol (Isopropanol) & Merck, Merck KGaA, Darmstadt & 1.096.341.011 \\
\hline Öl-rot-O & $\begin{array}{l}\text { Sigma, Sigma-Aldrich Chemie GmbH, Taufkir- } \\
\text { chen }\end{array}$ & $0-0625-25 g$ \\
\hline Paraformaldehyd & Merck, Merck KGaA, Darmstadt & 818715 \\
\hline Rneasy Mini-Kit (250) & Qiagen, Qiagen $\mathrm{GmbH}$, Hilden & 74106 \\
\hline Rnase Free Dnase-Set & Qiagen, Qiagen $\mathrm{GmbH}$, Hilden & 79254 \\
\hline iScript cDNA Synthesis Kit & Bio-Rad, Bio-Rad Laboratories $\mathrm{GmbH}$, München & $170-8891$ \\
\hline iQ SYBR Green Supermix & Bio-Rad, Bio-Rad Laboratories $\mathrm{GmbH}$, München & $170-8882$ \\
\hline Go Taq Green Master Mix & Promega, Promega $\mathrm{GmbH}$, Mannheim & 23266204 \\
\hline
\end{tabular}

Tab. 11: Geräte und Verbrauchsmaterialien

\begin{tabular}{|c|c|}
\hline Gerät & Hersteller \\
\hline Sterilbank & Biohazard Cleanair En 12469, Woerden, Niederlande \\
\hline Zellkulturinkubator & $\begin{array}{l}\text { Sanyo Electric Biomedical CO. Ltd, Japan. Ewald Innovations- } \\
\text { technik GmbH. Vertrieb Sanyo, Bad Nenndorf }\end{array}$ \\
\hline Zellzählgerät (CASY) & Schärfe System/Innovatis AG, Reutlingen \\
\hline $\begin{array}{l}\text { Mikroskop, Axiovert 200m/HAL } \\
100, \text { Axiocam MRm }\end{array}$ & Carl Zeiss Vision GmbH, Halbergmoos \\
\hline Software & Axiovision Zeiss, Carl Zeiss Vision $\mathrm{GmbH}$, Halbergmoos \\
\hline Thermoshaker & Thermostar, BMG Labtechnologies $\mathrm{GmbH}$, Offenburg \\
\hline Photometer & Tecan GENios Plus, Tecan Deutschland GmbH, Crailsheim \\
\hline Tiefkühlschrank unten & $\begin{array}{l}\text { Sanyo Electric Biomedical CO. Ltd, Japan. Ewald Innovations- } \\
\text { technik GmbH. Vertrieb Sanyo, Bad Nenndorf }\end{array}$ \\
\hline Tiefkühlschrank oben & Liebherr Hausgeräte Ochsenhausen $\mathrm{GmbH}$, Ochsenhausen \\
\hline Kühlschrank & Liebherr Hausgeräte Ochsenhausen $\mathrm{GmbH}$, Ochsenhausen \\
\hline Vortexer, MS 2 Minishaker & IKA GmbH \& Co. KG, Staufen \\
\hline Zentrifuge, klein & $\begin{array}{l}\text { Sigma } 2 \mathrm{~K} 15 \mathrm{C} \text {, Sigma Laborzentrifugen } \mathrm{GmbH} \text {, Osterode am } \\
\text { Harz }\end{array}$ \\
\hline Zentrifuge & HERMLE Z400K, HERMLE Labortechnik GmbH, Wehingen \\
\hline ELISA Reader & Genios plus, Tecan Trading AG, Switzerland \\
\hline Wasserbad & Memmert GmbH \& Co. KG, Schwabach \\
\hline
\end{tabular}


DNA Engine PTC-200

Mastercycler Gradient

Zentrifuge 5417C

Pipetten, 10-500 $\mu \mathrm{l}$

Pipetten, 10-20 ml

Pipettenspitzen

Pipettenboy

Zentrifugenröhrchen $15 \mathrm{ml}$

Präzisionsmultikanalpipette 100 $\mu \mathrm{l}, 150 \mu \mathrm{l}$

Verbrauchsmaterialien
Bio-Rad, Bio-Rad Laboratories GmbH, München Eppendorf, Wesseling-Berzdorf Eppendorf, Wesseling-Berzdorf Eppendorf, Wesseling-Berzdorf Eppendorf, Wesseling-Berzdorf Eppendorf, Wesseling-Berzdorf Eppendorf, Wesseling-Berzdorf Sarstedt, Sarstedt AG \& CO, Nümbrecht Eppendorf, Wesseling-Berzdorf Sarstedt, Sarstedt AG \& CO, Nümbrecht Eppendorf, Wesseling-Berzdorf

Herstellungsprotokoll für 1I MACS-Puffer:

- Supplementierung von EDTA (2 mmol) und BSA (0,5 \%) in PBS

- Sterilfiltration der Lösung.

\section{Markierungsprotokoll für Stro-1 (max. $10^{7}$ Zellen):}

$\begin{array}{ll}200 \mu \mathrm{l} & \text { PBS } \\ 4 \mu \mathrm{l} & \text { Stro-1 Antikörper } \\ 30 \mathrm{~min} & \text { Inkubation im Kühlschrank } \\ 1 \mathrm{ml} & \text { MACS-Puffer } \\ 10 \mathrm{~min} & \text { Zentrifugieren }(300 \times \mathrm{g}) \\ & \text { Überstand verwerfen } \\ 80 \mu \mathrm{l} & \text { MACS-Puffer } \\ 20 \mu \mathrm{l} & \text { Goat Anti-Mouse IgG MicroBeads } \\ 15 \mathrm{~min} & \text { Inkubation im Kühlschrank } \\ 1 \mathrm{ml} & \text { MACS-Puffer } \\ 10 \mathrm{~min} & \text { Zentrifugieren (300 } \mathrm{g}) \\ & \text { Überstand verwerfen }\end{array}$

MAC-Sortierung der markierten Zellen 
Markierungsprotokoll für CD133 (max. $10^{8}$ Zellen):

$300 \mu \mathrm{l}$

MACS-Puffer

$100 \mu \mathrm{l}$

FcR Blocking Reagent

$100 \mu \mathrm{l}$

CD133 MicroBeads

$30 \min$

Inkubation im Kühlschrank

$5 \mathrm{ml}$

MACS-Puffer

$10 \min$

Zentrifugieren $(300 \times \mathrm{g})$

Überstand verwerfen

MAC-Sortierung der markierten Zellen

Markierungsprotokoll für CD271 (max. 1077 Zellen):

$\begin{array}{ll}80 \mu \mathrm{l} & \text { MACS-Puffer } \\ 20 \mu \mathrm{l} & \text { FcR Blocking Reagent } \\ 10 \mu \mathrm{l} & \text { CD271 (LNGFR) Antikörper } \\ 10 \mathrm{~min} & \text { Inkubation im Kühlschrank } \\ 1 \mathrm{ml} & \text { MACS-Puffer } \\ 10 \mathrm{~min} & \text { Zentrifugieren (300 } \mathrm{g} \text { ) } \\ 70 \mu \mathrm{l} & \text { Überstand verwerfen } \\ 10 \mu \mathrm{l} & \text { MACS-Puffer } \\ 20 \mu \mathrm{l} & \text { FcR Blocking Reagent } \\ 15 \mathrm{~min} & \text { Anti-PE MicroBeads } \\ 1 \mathrm{ml} & \text { Inkubation im Kühlschrank } \\ 10 \mathrm{~min} & \text { MACS-Puffer } \\ & \text { Zentrifugieren (300 } \mathrm{g} \text { g) } \\ & \text { Überstand verwerfen } \\ & \text { MAC-Sortierung der markierten Zellen }\end{array}$




\section{Literaturverzeichnis}

Abe Y, Akamine A, Aida Y, Maeda K (1993):

Differentiation and mineralization in osteogenic precursor cell derived from fetal rat mandibular bone.

Calcif Tissue Int $\underline{52}, 365-371$

Aubin J (2001):

Regulation of osteoblast formation and function.

Rev Endocr Metab Disord 2, 81-94

Aubin J, Liu F:

The osteoblast lineage.

In: Principles of bone biology; hrsg. v. Bilezikian J, Raisz L, Rodan G; Academic Press, San Diego 1996, 51-68

Aubin J, Turksen K, Heersche J:

Osteoblastic cell lineage.

In: Cellular and molecular biology of bone, hrsg. v. Noda M; Academic Press,

New York 1993, 1-45

Aubin J, Liu F, Malaval L, Gupta A (1995):

Osteoblast and chondroblast differentiation.

Bone 17, 77-83

Aubin J, Liu F, Candeliere G (2002):

Single cell PCR methods for studying stem cells and progenitors.

Methods Mol Biol 185, 403-415

Avrami M (1939):

Kinetics of phase change I. General theory.

J Chem Phys $\underline{7}, 1103-1112$

Avrami M (1940):

Kinetics of phase change II. Transformation-time relations for random distribution of nuclei.

J Chem Phys $\underline{8}, 212-224$

Avrami M (1941):

Kinetics of phase change III. Granulation, phase change, and microstructure.

J Chem Phys $\underline{9}, 177-184$

Barry F, Boynton R, Liu B, Murphy J (2001):

Chondrogenetic differentiation of mesenchymal stem cells from bone marrow: differentiation-dependent gene expression of matrix components.

Exp Cell Res $\underline{268}, 189-200$

Batouli S, Miura M, Brahim J, Tsutsui T, Fisher L, Gronthos S, Robey G, Shi S (2003):

Comparison of stem-cell-mediated osteogenesis and dentinogenesis.

J Dent Res $\underline{8}, 976-981$

Bhargava U, Barlev M, Bellows C, Aubin J (1988):

Ultrastrucutral analysis of bone nodules formed in vitro by isolated fetal rat calvarial cells.

Bone $\underline{9}, 155-163$

Bianco P, Riminucci M, Gronthos S, Robey P (2001):

Bone marrow stromal cells: nature, biology and potential applications.

Stem Cells $\underline{19}$, 180-192 
Blau H, Brazelton T, Weimann J (2001):

The evolving concept of a stem cell: entity or function?

Cell $\underline{105}$, 829-841

Boone C, Mourot J, Grégoire F, Remacle C (2000):

The adipose conversion process: regulation by extracellular and intracellular factors. Reprod Nutr Dev 40, 325-358

Bridgewater L, Lefebvre V, de Crombrigghe B (1998):

Chondrocyte-specific enhancer elements in the Col11a2 gene resemble the Col2a1 tissue-specific enhancer.

J Biol Chem 273, $14998-15006$

Bruder S, Fink D, Caplan A (1995):

Mesenchymal stem cells in bone development, bone repair and skeletal regeneration therapy.

J Cell Biochem 트, 283-294

Bruder S, Jaiswal N, Haynesworth S (1997):

Growth kinetics, self-renewal, and the osteogenic potential of purified human mesenchymal stem cells during extensive subcultivation and following cryopreservation.

J Cell Biochem $\underline{64}$, 278-294

Bruder S, Ricalton N, Boynton R, Connolly T, Jaiswal N, Zaia J, Barry F (1998): Mesenchymal stem cell surface antigen SB-10 corresponds to activated leukocyte cell adhesion molecule and is involved in osteogenic differentiation.

J Bone Miner Res $\underline{13}$, 655-63

Caneva L, Soligo D, Cattoretti G, De Harven E, Lambertenghi Deliliers G (1995): Immuno-electron microscopy of human bone marrow stromal cells with anti-NFGR antibodies.

Blood Cells Mol Dis $\underline{21}, 73-85$

Caplan A (1991):

Mesenchymal stem cells.

J Orthop Res 9, 641-650

Caplan A, Boyan B:

Endochondral bone formation: the lineage cascade.

In: Bone, Vol. 8: Mechanisms of bone development and growth; hrsg. v. Hall B;

CRC Press; Boca Raton 1994, 1-46

Caplan A, Bruder S (2001):

Mesenchymal stem cells: building blocks for molecular medicine in the 21st century. Trends Mol Med 7, 259-264

Carney S, Muir H (1988):

The structure and function of cartilage proteoglycans.

Physiol Rev 68, 858-910

Casaccia-Bonnefil P, Carter B, Dobrowsky R, Chao M (1996):

Death of oligodendrocytes mediated by the interaction of nerve growth factor with its receptor $\mathrm{p} 75$.

Nature $\underline{383}, 716-719$

Chalazonitis A, Rothmann T, Chen J, Gershon M (1998):

Age-dependent differences in the effects of GDNF and NT-3 on the development of neurons and glia from neural crest-derived precursors immunoselected from the fetal rat gut: expression of GFRa-1 in vitro and in vivo.

Dev Biol 204, 385-406 
Chen S, Marino V, Gronthos S, Bartold P (2006):

Location of putative stem cells in human periodontal ligament.

J Periodontal Res $\underline{41}$, 547-553

Collin P, Nefussi J, Wetterwald A, Nicolas V, Bay-Levefre L, Fleisch H, Forest N (1992):

Expression of collagen, osteocalcin and bone alkaline phosphatase in a mineralizing rat osteoblastic cell culture.

Calcif Tissue Int $\underline{50}, 175-183$

Colter D, Class R, DiGirolamo C, Prockop D (2000):

Rapid expansion of recycling stem cells in cultures of plastic-adherent cells from human bone marrow.

Proc Natl Acad Sci U S A $\underline{97}$, 3213-3218

D’Aquino R, Graziano A, Sampaolesi M, Laino G, De Rosa A, Papaccio G (2007): Human postnatal dental pulp cells co-differentiate into osteoblasts and endotheliocytes: a pivotal synergy leading to adult bone tissue formation.

Cell Death Differ 14, 1162-1171

De Bari C, Dell'Accio F, Tylzanowski P, Luyten F (2001):

Multipotent mesenchymal stem cells from adult human synovial membrane.

Arthritis Rheum $\underline{44}$, 1928-1942

Dennis J, Carbillet J, Caplan A, Charbord P (2002):

The STRO-1+ marrow cell population is multipotential.

Cells Tissues Organs $\underline{170}, 73-82$

Di Stefano P, Johnson E (1988):

Identification of a truncated form of the nerve growth factor receptor.

Proc Natl Acad Sci U S A $\underline{85}, 270-274$

Ducy P, Kartensy G (1998):

Genetic control of cell differentiation in the skeleton.

Curr Opin Cell Biol 10, 614-619

Entenmann G, Hauner H (1996):

Reltionship between replication and differentiation in cultured human adipocyte precursor cells.

Am J Physiol 270, C1011-C1016

Eyre D (2002):

Collagen of articular cartilage.

Arthritis Res $\underline{4}, 30-35$

Fanfoni M, Tomellini M (1998):

The Johnson-Mehl-Avrami-Kolmogrov model: a brief review.

II Nuovo Cimento 20, 1171-1182

Ferrari G, Cusella-De Angelis G, Coletta M, Paolucci E, Stornaiuolo A, Cossu G, Mavillo F (1998):

Muscle regeneration by bone marrow-derived myogenic progenitors.

Science $\underline{279}, 1528-1530$

Fuchs E, Serge J (2000):

Stem cells: a new lease of life.

Cell $\underline{100}, 143-155$

Gay I, Chen S, MacDougall M (2007):

Isolation and characterization of multipotent human periodontal ligament stem cells.

Orthod Craniofac Res $\underline{10}$, 149-160 
Goldring M, Tsuchimochi K, ljiri K (2006):

The control of chondrogenesis.

J Cell Biochem $\underline{97}, 33-44$

Gorbenko O, Filonenko V, Gout I (2006):

Generation and characterization of monoclonal antibody against FABP4.

Hybridoma (Larchmt) 25, 86-90

Gronthos S, Graves S, Ohta S, Simmons P (1994):

The STRO $-1^{+}$fraction of adult human bone marrow contains the osteogenic precursors.

Blood 84, 4164-4173

Gronthos S, Mankani M, Brahim J, Robey P, Shi S (2000):

Postnatal human dental pulp stem cells (DPSCs) in vitro and in vivo.

Proc Natl Acad Sci U S A $\underline{97}$, 13625-13630

Gronthos S, Brahim J, Li W, Fisher L, Cherman N, Boyde A (2002):

Stem cell properties of human dental pulp stem cells.

J Dent Res 81, 531-535

Gronthos S, Zannettino A, Hay S, Shi S, Graves S, Kortesidis A (2003):

Molecular and cellular characterisation of highly purified stromal stem cells derived from human bone marrow.

J Cell Sci 116, 1827-1835

Hall B, Miyake T (2000):

All for one and one for all: condensations and initiation of skeletal development.

Bioessays 22, 138-147

Harada H, Kettunen P, Jung H, Mustonen T, Wang Y, Thesleff I (1999):

Localization of putative stem cells in dental epithelium and their association with Notch and FGF signaling.

J Cell Biol $\underline{147}, 105-120$

Hiller I (1965):

Modified Avrami equation for the bulk crystallization kinetics of spherulitic polymers.

J Polymer Sci A $\underline{3}, 3067-3078$

Huang G, Gronthos S, Shi S (2009):

Mesenchymal stem cells derived from dental tissues vs. those from other sources: their biology and role in regenerative medicine.

J Dent Res $\underline{88}, 792-806$

lohara K, Zheng L, Ito M, Tomokiyo A, Matsushita K, Nakashima M (2006):

Side population cells isolated from porcine dental pulp tissue with self-renewal and multipotency for dentinogenesis, chondrogenesis, adipogenesis, and neurogenensis.

Stem Cells 24, 2493-2503

Jilka R, Weinstein R, Bellido T, Parfitt A Mangolas S (1998):

Osteoblast programmed cell death (apoptosis): modulation by growth factors and cytokines.

J Bone Miner Res $\underline{13}$, 793-802

Jo Y, Lee H, Kook S, Choung H, Park J, Chung J, Coung Y, Kim E, Yang H, Choung $P$ (2007):

Isolation and characterization of postnatal stem cells from human dental tissues.

Tissue Eng 13, 767-773 
Jones E, Kinsey S, English A, Jones R, Strasynski L, Meredith D, Markham M, Jack A, Emery P, McGonagle D (2002):

Isolation and characterization of bone marrow multipotential mesenchymal progenitor cells.

Arthritis Rheum $\underline{46}, 3349-3360$

Joyner C, Bennett A, Tiffitt J (1997):

Identification and enrichment of human osteoprogenitor cells by using differentiation stage-specific monoclonal antibodies.

Bone 21, 1-6

Kashiba H, Noguchi K, Ueda Y, Senba E (1995):

Coexpression oft rk familiy members and low-affinity neutrophine receptors in rat dorsal root ganglion neurons.

Mol Brain Res $\underline{30}, 158-164$

Kemoun P, Laurencin-Dalicieux S, Rue J, Farges J, Gennero I, Conte-Auriol F, Briand-Mesange F, Gadelorge M, Arzate H, Narayanan A, Brunel G, Salles J (2007):

Human dental follicle cells aquire cementoblast features under stimulation by BMP-2/-7 and enamel matrix derivatives (EMD) in vitro.

Cell Tissue Res 329, 283-294

Kerkis I, Kerkis A, Dozortsev D, Stukart-Parsons G, Massironi S, Pereira L, Caplan A, Cerruti H (2006):

Isolation and characterization of a population of immature dental pulp stem cells expressing OCT-4 and other embryonic stem cell markers.

Cells Tissues Organs $\underline{184}, 105-116$

Kocher A, Schuster M, Szabolcs M, Takuma S, Burkhoff D, Wang J, Homma S, Edwards N, Itescu S (2001):

Neovascularization of ischemic myocardium by human bone-marrow-derived angioblasts prevents cardiomyocyte apoptosis, reduces remodeling and improves cardiac function.

Nat Med $\underline{7}, 430-436$

Koussoulakou D, Margaritis L, Koussoulakos S (2009):

A curriculum vitae of teeth: evolution, generation, regeneration.

Int J Biol Sci $\underline{5}, 226-243$

Kuznetsov S, Krebsbach P, Satomura K (1997):

Single-colony derived strains of human marrow stromal fibroblasts form bone after transplantation in vivo.

J Bone Miner Res 므, 1335-1347

Laino G, d'Aquino R, Graziano A, Lanza V, Carinci F, Naro F, Pirozzi G, Papaccio G (2005):

A new population of human adult dental pulp stem cells: a useful source of living autologous fibrous bone tissue (LAB).

J Bone Miner Res 20, 1394-1402

Lefebvre V, Smits P (2005):

Transcriptional control of chondrocyte fate and differentiation.

Birth Defects Res C Embryo Today $\underline{75}$, 200-212 
Liu Y, Li H, Tanaka K, Tsumaki N, Yamada Y (2000):

Identification of an enhancer sequence within the first intron required for cartilagespecific transcription of the alpha2(XI) collagen gene.

J Biol Chem 275, 12712-12718

Makino S, Fukuda K, Miyoshi S (1999):

Cardiomyocytes can be generated from marrow stromal cells in vitro.

$\mathrm{J}$ Clin Invest 103, 697-705

Malaval L, Modrowski D, Gupta A, Aubin J (1994):

Cellular expression of bone-related proteins during in vitro osteogenesis in rat bone marrow stromal cell cultures.

J Cell Physiol 158, 555-572

Mangolas S (2000):

Birth and death of bone cells: basic regulatory mechanisms and implications for the pathogenesis treatment of osteoporosis.

Endocr Rev 21, 115-137

Mankin H, Trasher A (1975):

Water content and binding in normal and osteoarthritic human cartilage.

J Bone Joint Surg Am $\underline{57}$, 76-80

Månsson B, Wenglén C, Mörgelin M, Saxne T, Heinegård D (2001):

Association of chondroadherin with collagen type II.

J Biol Chem 276, 32883-32888

Mendler M, Eich-Bender S, Vaughan L, Winterhalter K, Bruckner P (1989):

Cartilage contains mixed fibrils of collagen types II, IX, and XI.

J Cell Biol 108, 191-197

Miller S (1987):

The bone lining cells: a distinct phenotype?

Calcif Tissue Int 41, 1-5

Miltenyi Biotec

www.miltenyibiotec.com

Miura M, Gronthos S, Zhao M, Lu B, Fisher L, Robey P, Shi S (2003):

Stem cells from human exfoliated deciduous teeth.

Proc Natl Acad Sci U S A 100, 5807-5812

Miura M, Chen X, Allen M, Bi Y, Gronthos S, Seo B, Lakhani S, Flavell R, Feng X, Robey P, Young M, Shi S (2004):

A crucial role of caspase- 3 in osteogenic differentiation of bone marrow stromal cells J Clin Invest 114, 1704-1713

Morsczeck C (2006):

Gene expression of runx2, osterix, c-fos, DLX-3, DLX-5 \& MSX-2 in dental follicle cells during osteogenetic differentiation in vitro.

Calcif Tissue Int $\underline{78}$, 98-102

Morsczeck C, Gotz W, Schierholz J, Zeilhofer F, Kuhn U, Mohl C, Sippel C, Hoffmann K (2005 a):

Isolation of precursor cells (PCs) from human dental follicle of wisdom teeth.

Matrix Biol 24, 155-165

Morsczeck C, Moehl C, Gotz W, Heredia A, Schaffer T, Eckstein N, Sippel C, Hoffmann K (2005 b):

In vitro differentiation of human dental follicle cells with dexamethansone and insulin.

Cell Biol Int $\underline{29}, 567-575$ 
Morsczeck C, Reichert T, Völlner F, Gerlach T, Driemel O (2007):

Stand der humanen dentalen Stammzellforschung.

Mund Kiefer Gesichtschir 11, 259-266

Orlic D, Kajstura J, Chimenti S, Jakoniuk I, Anderson S, Li B, Pickel J, McKay R, Nadal-Girnard B, Bodine D, Leri A, Anversa P (2001):

Bone marrow cells regenerate infracted myocardium.

Nature $\underline{410}, 701-705$

Owen T, Aranow M, Shalhoub V, Barone L, Wilming L, Tessinari M, Kennedy M, Pockwinse S, Lian J, Stein G (1990):

Progressive development of the rat osteoblast phenotype in vitro: reciprocal relationship in expression of genes associated with osteoblast proliferation and differentiation during formation of the bone extracellular matrix.

J Cell Physiol 143, 420-430

Papaccio G, Graziano A, d'Aquino R, Graziano M, Pirozzi G, Menditti D (2006):

Long-term cryopreservation of dental pulp stem cells (SB-DPSCs) and their differentiated osteoblasts: a cell source for tissue repair.

J Cell Physiol 208, 319-325

Parfitt A (1994):

Osteonal and hemi-osteonal remodeling: the spatial and temporal framework for signal traffic in adult human bone.

$\mathrm{J}$ Cell Biochem 55, 273-286

Petersen B, Bowen W, Patrene K, Mars W, Sullivan A, Murase N, Boggs S, Greenberger J, Goff J (1999):

Bone marrow as a potential source of hepatic oval cells.

Science 284, 1168-1170

Pittenger M, Mackay A, Beck S, Jaiswal R, Douglas R, Mosca J, Moorman M, Simonetti D, Craig S, Marshak D (1999):

Multilineage potential of adult mesenchymal stem cells.

Science 284, 143-147

Potten C (1998):

Stem cells in gastrointestinal epithelium: numbers, characteristics and death.

Philos Trans R Soc Lond B Biol Sci 353, 821-830

Prockop D (2001):

Stem cell research has only just begun.

Science 293, 211-212

Quirici N, Soligo D, Bossolasco P, Servida F, Lumini C, Lambertenghi Deliliers G (2002):

Isolation of bone marrow mesenchymal stem cells by anti-nerve growth factor receptor antibodies.

Exp Hematol $\underline{30}, 783-791$

Rickard D, Kassem M, Hefferan T, Sarkar T, Riggs L (1996):

Isolation and characterization of osteoblast precursor cells from human bone marrow. J Bone Miner Res 11, 312-324

Rodan G (1997):

The missing bone.

Cell 89, 677-680

Rosen E, MacDougald O (2006):

Adipocyte differentiation from the inside out.

Nature $\underline{7}, 885-896$ 
Rosen E, Walkey C, Puigserver P, Spiegelmann B (2000):

Transcriptional regulation of adipogenesis.

Genes Dev 14, 1293-1307

Rossert J, Terraz C, Dupont S (2000):

Regulation of type I collagen genes expression.

Nephrol Dial Transplant $\underline{6}, 66-68$

Rudge J, Li Y, Pasnikowski E, Mattsson K, Pan L, Yancopoulos G, Wiegand S, Lindsay R, Ip N (1994):

Neutrophic factor receptors and their signal transduction capabilities in rat astrocytes.

Eur J Neurosci $\underline{6}$, 693-705

Saunders M (2009):

Transplacental transport of nanomaterials.

Wiley Interdiscip Rev Nanomed Nanobiotechnol 1, 671-684

Schiebler T, Schmidt W:

In: Anatomie; 8. Auflage; Springer-Verlag, Berlin, 1999 a, 428-431

Schiebler T, Schmidt W:

In: Anatomie; 8. Auflage; Springer-Verlag, Berlin, 1999 b, 63-64

Sekiya I, Tsuji K, Koopman P, Watanabe H, Yamada Y, Shinomiya K, Nifuji A, Noda M (2000):

Sox9 enhances aggrecan gene promoter/enhancer activity and is up-regulated by retinoic acid in a cartilage-derived cell line, TC 6.

J Biol Chem 271, 10738-10744

Seo B, Miura M, Gronthos S, Bartold P, Batouli S, Brahim J, Young M, Robey P, Wang C, Shi S (2004):

Investigation of multipotent postnatal stem cells from human periodontal ligament. Lancet $\underline{364}$, 149-155

Shi S, Gronthos S (2003):

Perivascular niche of postnatal mesenchymal stem cells in human bone marrow and dental pulp.

J Bone Miner Res 18 , 696-704

Shi S, Robey P, Gronthos S (2001):

Comparison of human dental pulp and bone marrow stromal cells by cDNA microarray analysis.

Bone 29, 532-539

Shi S, Bartold P, Miura M, Seo B, Robey P, Gronthos S (2005):

The efficacy of mesenchymal stem cells to regenerate and repair dental structures.

Orthod Craniofac Res $\underline{8}, 191-199$

Shmelkov S, St Clair R, Lyden D, Rafi S (2005):

AC133/CD133/Prominin-1.

Int J Biochem Cell Biol 37, 715-719

Simmons PJ, Torok-Storb B (1991):

Identification of stromal cell precursors in human bone marrow by a novel monoclonal antibody, STRO-1.

Blood $\underline{78}, 55-62$

Sloan A, Waddington R (2008):

Dental pulp stem cells: what, where, how?

Int J Paediatr Dent 19, 61-70 
Smith A, Patel M, Graham L, Sloan A, Cooper P (2005):

Dentine regeneration: the role of stem cells and molecular signaling.

Oral Biosci Med 2, 127-132

Sonoyama W, Liu Y, Fang D, Yamaza T, Seo B, Zhang C, Liu H, Gronthos S, Wang C, Shi S, Wang S (2006):

Mesenchymal stem cell-mediated functional tooth regeneration in swine.

PLoS ONE 1, e79

Sonoyama W, Liu Y, Yamaza T, Tuan R, Wang S, Shi S, Huang G (2008):

Characterization of the apical papilla and its residing stem cells from human immature permanent teeth: a pilot study.

J Endod 34, 166-171

Steward K, Monk P, Walsh S, Jefferiss C, Letchford J, Beresford J (2003):

STRO-1, HOP-26 (CD63), CD49a and SB-10 (CD166) as markers of primitive human marrow stromal cells and their more differentiated progeny: a comparative investigation in vitro.

Cell Tissue Res $\underline{313}$, 281-290

Tacchetti C, Tavella S, Dozin B, Quarto R, Robino G, Cancedda R (1992):

Cell condensation in chondrogenic differentiation.

Exp Cell Res 200, 26-33

Takahashi K, Yamanaka S (2006):

Induction of pluripotent stem cells from mouse embryonic and adult fibroblast cultures by defined factors.

Cell $\underline{126}, 663-676$

Takeda T, Tezuka Y, Horiuchi M, Hosono K, lida K, Hatakeyama D, Miyaki S, Kunisada T, Shibata T, Tezuka K (2008):

Characterization of dental pulp stem cells of human tooth germs.

J Dent Res 87, 676-681

Thomson T, Rettig W, Chesa P, Green S, Mena A, Old L (1988):

Expression of human nerve growth factor receptor on cells derived from all three germ layers.

Exp Cell Res 174, 533-539

Tondreau T, Meuleman N, Delforge A, Dejeneffe M, Leroy R, Massy M, Mortier C, Bron D, Lagneaux L (2005):

Mesenchymal stem cells derived from CD133-positive cells in mobilized peripheral blood and cord blood: proliferation, Oct4 expression, and plasticity.

Stem Cells 23, 1105-1112

Tontonoz P, Hu E, Spiegelmann B (1994 a):

Stimulation of adipogenesis in fibroblasts by PPAR $\gamma 2$, a lipid-activated transcription factor.

Cell $\underline{79}, 1147-1156$

Tontonoz P, Hu E, Budavari A, Spiegelmann B (1994 b):

mPPAR gamma 2: tissue-specific regulator of an adipocyte enhancer.

Genes Dev $\underline{8}, 1224-1234$

Tuan R (2004):

Biology of developmental and regenerative skeletogenesis.

Clin Orthop Relat Res $\underline{427}$ (Suppl), 105-117

Vekilov P (2010):

Phase transitions of folded proteins

Soft Matter $\underline{6}, 5254-5272$ 
Vroemen M, Weidner N (2003):

Purification of schwann cells by selection of p75 low affinity nerve growth factor receptor expressing cells from adult peripheral nerve.

J Neurosci Methods $\underline{124}, 135-143$

Waddington R, Youde S, Lee C, Sloan A (2009):

Isolation of dinstinct stem cell populations from dental pulp.

Cells Tissues Organs $\underline{189}$, 268-274

Wakitani S, Saito T, Caplan A (1995):

Myogenic cells derived from rat bone marrow mesenchymal stem cells exposed to 5acacytidine.

Muscle Nerve $\underline{18}, 1417-1426$

Williams R, Takahashi T, Hirsh A (1992):

The kinetics of autolysis in osmotically stressed sea urchin eggs.

Thermochim acta $\underline{203}$, 493-501

Williams R, Hirsh A, Meryman H, Takahashi T (1993):

The high-order kinetics of cytolysis in stressed red cells.

J Therm Anal $\underline{40}$, 857-862

Woodbury D, Schwarz E, Prockop D, Black I (2000):

Adult rat and human bone marrow stromal cells differentiate into neurons.

J Neurosci Res 61, 364-370

Yamada Y, Fujimoto A, Ito A, Yoshimi R, Ueda M (2006):

Cluster analysis and gene expression profiles: a CDNA microarray system-based comparison between human dental pulp stem cells (hDPSCs) and human mesenchymal stem cells (hMSCs) for tissue engineering cell therapy.

Biomaterials 27, 3766-3781

Yen A, Sharpe P (2006):

Regeneration of teeth using stem cell-based tissue engineering.

Expert Opin Biol Ther $\underline{6}$, 9-16

Yin A, Miraglia S, Zanjani E, Almeida-Porada G, Ogawa M, Leary A, Olweus J, Kearny J, Buck D (1997):

AC 133, a novel marker for human hematopoietic stem and progenitor cells.

Blood 90, 5002-5012

Young M (2003):

Bone matrix proteins: their function, regulation, and relationship to osteoporosis.

Osteoporos Int 14 (Suppl 3), 35-42

Zhang W, Walboomers X, Shi S, Fan M, Jansen J (2006):

Multilineage differentiation potential of stem cells derived from human dental pulp after cryopreservation.

Tissue Eng 12, 2813-2823 


\section{Danksagung}

An erster Stelle danke ich Herrn Prof. Dr. med. Dr. med. dent. K. G. Wiese, meinem Doktorvater, für die Überlassung des Themas dieser Dissertation, für sein Mitwirken, seine Hilfsbereitschaft und seine fachlichen Anregungen. Darüber hinaus gilt mein Dank inm und Herrn Dipl.-Biol. Dr. rer. nat. H. Rolf für die vorbildliche Unterstützung und Betreuung.

Danken möchte ich auch Frau Jutta Schulz, Mitarbeiterin der Abteilung für Mund-, Kiefer- und Gesichtschirurgie, für die Hilfe bei der Ausführung der Zellversuche, sowie Frau Dr. phil. nat. Sabine Niebert für ihre Unterstützung bei den molekularbiologischen Analysen und Auswertungen.

Ebenso möchte ich mich bei Dr. rer. nat. Jörg Hallmann für seine stete Hilfsbereitschaft und sein tatkräftiges Engagement bedanken. Des Weiteren gilt mein besonderer Dank meinen Eltern, sowie M. Sc. Claudia Floren und Dr. med. dent. Valentina Hrasky für ihre Bemühungen bei der Durchsicht der Dissertation. 